
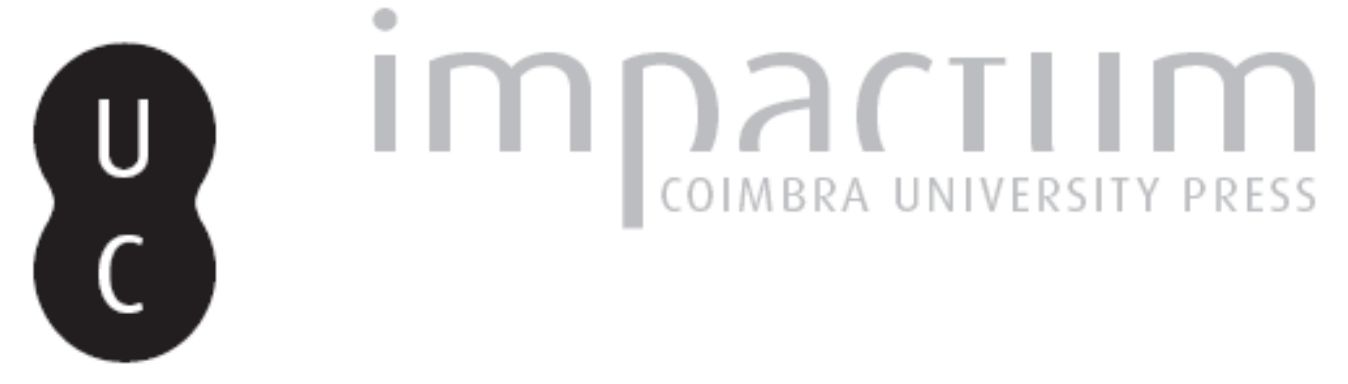

\title{
O euro: das promessas do paraíso às ameaças de austeridade perpétua
}

Autor(es): $\quad$ Nunes, António José Avelãs

Publicado por: Faculdade de Direito da Universidade de Coimbra

URL persistente:

URI:http://hdl.handle.net/10316.2/35526

DOI:

DOI:http://dx.doi.org/10.14195/0870-4260_56_1

Accessed : $\quad$ 26-Apr-2023 16:35:10

A navegação consulta e descarregamento dos títulos inseridos nas Bibliotecas Digitais UC Digitalis, UC Pombalina e UC Impactum, pressupõem a aceitação plena e sem reservas dos Termos e Condições de Uso destas Bibliotecas Digitais, disponíveis em https://digitalis.uc.pt/pt-pt/termos.

Conforme exposto nos referidos Termos e Condições de Uso, o descarregamento de títulos de acesso restrito requer uma licença válida de autorização devendo o utilizador aceder ao(s) documento(s) a partir de um endereço de IP da instituição detentora da supramencionada licença.

Ao utilizador é apenas permitido o descarregamento para uso pessoal, pelo que o emprego do(s) título(s) descarregado(s) para outro fim, designadamente comercial, carece de autorização do respetivo autor ou editor da obra.

Na medida em que todas as obras da UC Digitalis se encontram protegidas pelo Código do Direito de Autor e Direitos Conexos e demais legislação aplicável, toda a cópia, parcial ou total, deste documento, nos casos em que é legalmente admitida, deverá conter ou fazer-se acompanhar por este aviso.

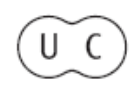




\section{UNIVERSIDADE DE COIMBRA}

FACULDADE DE DIREITO

\section{BOLETII DE CIÊECIAS ECONÓMICAS}

VOLUME LVI

$\begin{array}{llll}2 & 0 & 1 & 3\end{array}$

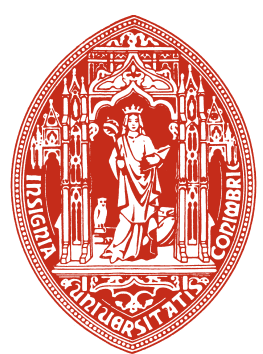

COIMBRA 


\title{
O EURO: DAS PROMESSAS DO PARAÍSO ÀS AMEACAS DE AUSTERIDADE PERPÉTUA*
}

\author{
"Quem nunca quer questionar nada \\ corre o risco de nunca entender nada" \\ FRÉDÉRIC LORDON
}

1. Foi certamente sábia e bem intencionada a ideia que presidiu à criação (abril/1951) da primeira das comunidades europeias, a CECA (Comunidade Europeia do Carvão e do Aço). Ao colocar sob uma autoridade comum o 'governo' do carvão e do aço, procurava-se evitar que os conflitos de interesses à volta destes materiais estratégicos (nomeadamente entre a Alemanha e a França) condenassem os povos a uma nova guerra.

* Utilizo neste artigo reflexões e trechos de dois livros meus relativamente recentes: $A$ Crise..., cit. e $\mathrm{O}$ estado..., cit.

Ofereço este artigo ao Doutor Luís Pedro Cunha, que me sucedeu como Diretor do Boletim de Ciências Económicas, e aos Colegas do Conselho de Redação. Estou certo de que eles farão muito melhor do que eu, honrando a memória do fundador deste Boletim, Doutor José Joaquim Teixeira Ribeiro, e acrescentando prestígio ao prestígio da nossa Faculdade.

Com este gesto não pretendo, evidentemente, comprometê-los com as ideias que aqui defendo. A responsabilidade pelos 'crimes' cometidos é exclusivamente minha.

Salvo um ou dois apontamentos este texto ficou concluído em 20.12.2013. 
Mas a história mudou quando se começou a pensar no mercado comum, dando início ao processo que levaria ao Tratado de Roma (1957) e à criação da Comunidade Económica Europeia (CEE). Vivia-se então o período áureo do keynesianismo e das políticas keynesianas, mas a verdade é que, por mais estranho que pareça, a filosofia e a estrutura da CEE foram profundamente marcadas pelas concepções liberais em matéria de política económica.

Chegado o momento do votar o Tratado de Roma, Pierre Mendès-France foi um dos poucos deputados que acompanharam os comunistas franceses no voto contra a ratificação do Tratado, voto que, com rara clarividência, justificou nestes termos: "O projeto do mercado comum, tal como nos é apresentado, baseia-se no liberalismo clássico do século XIX, segundo o qual a concorrência pura e simples regula todos os problemas. A abdicação de uma democracia pode assumir duas formas, seja a de uma ditadura interna que entrega todos os poderes a um homem 'providencial', seja a delegação dos seus poderes a uma autoridade exterior, que, em nome da técnica, exercerá na realidade o poder político, pois em nome de uma economia sã chega-se facilmente à imposição de uma política monetária, orçamental, social, em suma, uma política, no sentido mais amplo do termo, nacional e internacional". ${ }^{1}$

Desde o início do processo, os críticos do Tratado de Roma deram-se conta de que o "espírito do mercado comum" acabaria por privar os estados-membros dos meios e das competências indispensáveis para assegurar o controlo da economia pelo poder político democrático. Talvez por isso, Mendès-France defendeu na Assembleia Nacional francesa (janeiro/1957) que o projeto de criação do mercado comum europeu devia ser acompanhado da exigência da "igualização

${ }^{1}$ Cfr. ATTAC, “Constitution..., cit., 7. 
dos encargos e da generalização rápida dos benefícios sociais de todos os países do mercado comum". ${ }^{2}$

Como hoje é evidente, a história da 'Europa' desde o Tratado de Roma até à União Europeia confirma plenamente estes receios e previsões: o processo de integração europeia seguiu o caminho contrário ao apontado pelo então deputado radical. O "espírito do mercado comum" acabou por conduzir à "abdicação da democracia”.

Hoje, estudos vários mostram que os tecnocratas que prepararam os dossiês que orientaram os Chefes de Estado e de Governo dos seis países fundadores do Mercado Comum tinham perfeita consciência de que a opção pelo liberalismo nas relações entre os estados-membros do mercado comum arrastava consigo a adoção de soluções liberais no plano interno de cada estado.

Passada a fase da CECA, o projeto do mercado comum visou pôr de pé uma estrutura económico-política que esvaziasse o 'perigo' de vitória eleitoral dos partidos comunistas na Itália e na França e que, no ambiente próprio daqueles tempos de guerra fria, servisse de tampão à influência da URSS. Por isso (e também porque as empresas americanas instaladas na Europa representavam então a $3 .^{\mathrm{a}}$ economia mundial) os EUA apostaram no projeto 'Europa'. Do lado europeu, alguns viram neste projeto a resposta adequada da Europa ao défi américain. ${ }^{3}$

Por outro lado, todos os seus promotores tiveram a consciência (incluindo os dirigentes socialistas) de que a 'Europa' liberal que começavam a pôr de pé iria ferir de morte a

${ }^{2}$ Ver Journal Officiel de la Republique Française, 19.1.1957, 159-166.

3 Cfr. Jean Jacques Servan-Schreiber, Le Défi Américain, Paris, Denoël, 1967 (trad. port., América: Desafio ao Futuro, Lisboa, Livraria Bertrand, 1968). 
"Europa social”. ${ }^{4}$ Nestas condições, a 'morte' da 'Europa social' para dar vida à 'Europa do capital' terá de considerar-se um crime cometido com dolo (pelo menos com dolo eventual).

Embora admitindo a livre circulação de pessoas (sempre condicionada...), as liberdades de circulação de serviços, de mercadorias e de capitais, bem como a liberdade de estabelecimento, foram sempre assumidas e proclamadas como as verdadeiras liberdades fundamentais. A 'falecida' Constituição Europeia consagrava isto mesmo no art. I-4. ${ }^{\circ}$, sob a epígrafe liberdades fundamentais. Após a derrota do 'projeto constitucional' e para evitar o escândalo de se proclamarem como liberdades fundamentais estas liberdades do capital e não as que normalmente integram a tábua dos direitos, liberdades e garantias das pessoas, os construtores da 'Europa' resolveram retirar este texto do Tratado de Lisboa. Mas nós sabemos - porque eles não se cansam de o afirmar em todos os tons - que esta é apenas uma mudança cosmética para europeu ver. $\mathrm{Na}$ essência, tudo continua na mesma: aquelas liberdades do capital são mesmo as liberdades fundamentais que contam nesta 'Europa' do capital.

Segundo um seu ilustre colaborador e biógrafo, Mitterrand confessava, em 1983, estar "dividido entre duas ambições, a da construção da Europa e a da justiça social". ${ }^{5}$ Era o reconhecimento de que a justiça social não tinha lugar na 'Europa' em construção desde 1957. E, como é sabido, Mitterrand optou pela construção da 'Europa', sacrificando a justiça social. Esta tem sido, desde o início do processo de integração europeia, a opção dos partidos socialistas e sociais-democratas europeus.

Alguns anos mais tarde, logo a seguir à queda do Muro de Berlim (9.11.1989), Michel Rocard reconhecia, com

${ }^{4}$ F. DenOrd e A. Schwartz (ob. cit.) citam um deputado socialista francês (André Phillip): “Eu, socialista, preferiria ter uma Europa liberal a não a ter de todo".

5 Apud Jacques Attali, ob. cit., 399. 
grande frieza - seguindo, afinal, a lição de Mitterrand -, que "as regras do jogo do capitalismo internacional impedem qualquer política social audaciosa”, aceitando que, "para fazer a Europa, é preciso assumir as regras deste jogo cruel”. Para fazer a Europa, é, pois, necessário, segundo este destacado dirigente socialista, assumir as regras deste "jogo cruel" [as regras do jogo impostas pelo dito capitalismo internacional], vergando-se à lógica implacável da mercadização da economia e da vida, "feita pela Europa, graças à Europa e por causa da Europa", como reconhece Pascal Lamy, outro alto dirigente socialista, então Diretor-Geral da OMC. ${ }^{6}$

Confissões como as de Rocard e Pascal Lamy refletem concepções que equivalem à morte da política e ao reconhecimento de que a soberania reside nos mercados, ideia tão sugestivamente expressa nesta síntese espantosa de Joschka Fisher $^{7}$ (ex-dirigente de Os Verdes e ex-Ministro dos Negócios Estrangeiros de um governo alemão liderado pelo SPD): "ninguém pode fazer política contra os mercados". Mercados Über Alles!

São confissões que traduzem, em boa verdade, o pensamento hoje dominante na social-democracia europeia, que relega as 'preocupações sociais' para o plano dos sonhos impossíveis, falando delas como quem exibe uma velha jóia de família, umas vezes envergonhadamente, outras vezes apenas para efeitos publicitários, para calar a (má) consciência e 'ganhar o céu'. Quando falam a sério, os dirigentes socialistas acreditam que não há nada de relevante a fazer, no que toca à justiça social, no quadro de políticas públicas que não querem pôr em causa as regras do jogo do capitalismo internacional, ditadas pela ideologia neoliberal dominante.

As desculpas de 'inocência' ou de 'ingenuidade' (que não podem aceitar-se no plano da ação e da responsabilidade

\footnotetext{
${ }^{6}$ Citações colhidas em S. Halimi, "As promessas..., cit., 3.

7 Apud U. Beck, ob. cit., 58.
} 
políticas, sobretudo quando a crítica lembra os perigos que se correm) acabaram com a aprovação do Tratado de Maastricht, que alterou profundamente a "natureza ideológica da comunidade": esta passou a ser dirigida segundo princípios "ultraconservadores", privando os estados-membros de autonomia em matéria de política monetária, cambial e orçamental e pondo em causa abertamente o chamado modelo social europeu.

No que me diz respeito, sinto-me confortado nas críticas que venho fazendo há anos à cedência da social-democracia europeia ao ideário neoliberal por ver que, em livro recente, João Ferreira do Amaral não poupa nas palavras com que responsabiliza os socialistas europeus (incluindo o PS português) por terem construído este "mundo maastrichtiano": "a culpa de o tratado ter sido aprovado cabe por inteiro aos partidos socialistas europeus", porque "não estiveram à altura da situação e aprovaram sem reservas o Tratado de Maastricht" [como agora, digo eu, aprovaram o Tratado Orçamental, que aperta ainda mais o colete de forças maastrichtiano]. "Este desvio para a direita por parte do socialismo europeu (...) - continua o Professor do ISEG - foi dos maiores erros que os socialistas poderiam ter cometido. O Tratado de Maastricht atacava o modelo social europeu e não dava margem para os partidos socialistas ou social-democratas prosseguirem políticas informadas pelos valores que tradicionalmente defendiam". 8

Os arquitetos da 'Europa' sempre souberam que as $l i$ berdades fundamentais de que falo atrás, junto com as regras comuns em matéria de concorrência, implicavam o abatimento das soberanias nacionais. ${ }^{9}$ A consciência disto mesmo torna

${ }^{8}$ Ver J. Ferreira do Amaral, Porque devemos sair do euro, cit., 99/100.

9 Cfr. F. Denord, ob. cit. 
hoje inequívoco que o desenho da CEE significou, deste ponto de vista, uma primeira vitória do liberalismo alemão sobre o intervencionismo francês, construído no após-guerra (forte setor empresarial do estado, planificação pública da economia e sistema público de segurança social). O liberalismo consagrado no Tratado fundador de 1957 não era ainda o neoliberalismo (à moda de Hayek e de Friedman). Era uma espécie de liberalismo do possível. Mas o projeto 'Europa' “apresentou-se desde o primeiro dia como uma máquina para liberalizar". ${ }^{10}$

2. A partir do Tratado de Roma, o processo de integração europeia passou a decorrer sem a participação democrática dos cidadãos e dos povos da Europa nos processos de discussão e de decisão: a Europa dos negócios foi sendo construída em segredo (como convém aos negócios), “à porta fechada", "ignorando sempre a população"."11

Por isso, o chamado défice democrático vem sendo denunciado como vício estrutural (uma espécie de 'pecado original') do processo de construção da 'Europa': “a história da construção europeia é, como sabemos, também a história do seu défice democrático". ${ }^{12}$ Construída, nos seus pontos essenciais, em função dos interesses do Big Business, contra os interesses dos povos europeus, esta 'Europa' é tudo menos um espaço solidário, tudo menos uma entidade que respeite a vontade dos cidadãos, a dignidade dos povos da Europa e a igualdade entre os estados-membros soberanos. ${ }^{13}$

A história desta Europa do capital mostra, com efeito, que ela assentou sempre numa atitude de reserva mental (es-

\footnotetext{
${ }^{10}$ Cfr. B. Cassen, "Ressurreição..., cit.

11 Cfr. J. Habermas, Um Ensaio..., cit., 66 e 167.

12 Cfr. A. Lechevalier/G. Wasserman, ob. cit., 55.

13 Para mais desenvolvimentos, ver o meu livro A Constituição Europeia..., cit.
} 
camoteando aos povos da Europa o verdadeiro significado da cada passo dado), numa política dos 'pequenos passos', numa política do facto consumado (há quem fale de método Monnet), na "mentira política institucionalizada, na hipocrisia, no ilusionismo e na abdicação generalizada da vontade". ${ }^{14}$ Nunca (ou muito raramente) foi dada a palavra ao povo, com o argumento de que o povo não percebe o que está em causa e não tem capacidade para perspetivar o futuro, insinuando estes 'déspotas pseudo-esclarecidos' que, se certas decisões (as mais importantes para a vida dos povos) ficassem dependentes da vontade popular, a História nunca avançaria.

Pura ilusão ou lamentável ignorância. Esquecem que o motor da História não são as façanhas 'iluminadas' de alguns 'eleitos'. O motor da História é a luta de classes (di-lo o Manifesto Comunista: "a história da humanidade até aos nossos dias é a história da luta de classes"). Esquecem que "quem construiu Tebas das sete portas" (socorro-me do famoso poema de Brecht) não foram os reis de que falam os livros, mas "aqueles que arrastaram os blocos de pedra". Esquecem que quem faz a História, citando agora Miguel Torga, é o povo "que nunca traiu, o que dá esperança, o das revoluções populares, o que trabalha dia e noite sem esmorecer, o que acaba por ter sempre a última palavra nos acontecimentos, o do arado e do remo, o que não cabe nas crónicas".

Conhecido o resultado do referendo sobre a chamada Constituição Europeia, o Presidente Jacques Chirac teve o bom senso de afirmar: "os cidadãos dizem não à Europa porque recusam a Europa como ela é". ${ }^{15}$ O respeito pela vontade dos povos imporia que se arrepiasse caminho e se começasse a construir uma Europa diferente da que tinha sido construída até então. Em vez disso, os dirigentes europeus, defenso-

14 Cfr. J. Généreux, ob. cit., 14.

${ }^{15}$ Ver Le Monde Diplomatique (ed. port.), julho/2005. 
res do "pensamento único euro-beato" (Jacques Généreux), continuaram afanosamente a sua 'cruzada', dando corpo a uma 'Europa' que os seus cidadãos não querem.

A aprovação do Tratado de Lisboa (dezembro/2007) foi mais um passo a confirmar, escandalosamente, o défice democrático de todo o processo de construção europeia. A imposição deste tratado é a confissão solene de que os seus construtores querem impor "a Europa como ela é", ainda que contra a vontade dos povos europeus. Como todos os dirigentes europeus proclamaram, este novo Tratado só deixou de se chamar 'constituição', mantendo tudo o que era a essência da 'falecida' Constituição Europeia, tanto no que se refere à estrutura dos poderes políticos como no que tange às questões económicas, financeiras e sociais. Por isso o fizeram aprovar longe da 'populaça', no ambiente 'amigo' e 'confortável' dos parlamentos nacionais - que já tinham aprovado, por larguíssima maioria, a 'constituição europeia' que os povos da França e da Holanda recusaram em referendo -, fartinhos de saber que "os cidadãos (...) recusam a Europa como ela é”, a Europa tal como constava daquela 'Constituição'.

Mas a crise atual na Europa (crise do euro, crise da 'Europa') veio tornar evidente que esta crise do capitalismo (e crise da Europa capitalista) é também uma crise da democracia. Autores vários convergem nesta análise. Tomemos Ulrich Beck.

Segundo este destacado sociólogo alemão, "os governantes [governos e parlamentos] votam a favor da austeridade, as populações votam contra”.

Os governos adotam um "socialismo de estado para os ricos e os bancos" e aplicam as receitas do "neoliberalismo para a classe média e os pobres".

"Os governos impõem "um sistema gerador de tanta desigualdade e injustiça, que imputa, escandalosamente, aos grupos mais fracos os custos resultantes de um sistema financeiro que ficou descontrolado". Mas "a Europa [os povos da 
Europa] e a sua juventude estão unidos na raiva por causa de uma política que salva bancos com quantias de dinheiro inimagináveis, mas desperdiça o futuro das gerações jovens".

A situação atual na Europa - conclui Beck - carateriza-se pela "assimetria entre poder e legitimidade. Um grande poder e pouca legitimidade do lado do capital e dos estados [os estados que configuram a ditadura do grande capital financeiro. AN], um pequeno poder e uma elevada legitimidade do lado daqueles que protestam". ${ }^{16}$

É um diagnóstico certeiro este: o estado [o estado capitalista] é o estado do capital. E é também um diagnóstico preocupante, porque, se o poder do estado (do estado do capital) carece de legitimidade, está em causa a democracia, ficando a nu a ditadura que permite ao capital sem legitimidade submeter os que, apesar de terem elevada legitimidade, têm um pequeno poder. Esta é, a meu ver, a situação em que vivemos. A crise do capitalismo veio pôr em evidência a natureza de classe do estado: o estado capitalista é hoje a ditadura do grande capital financeiro.

Acresce que o referido défice democrático vem-se agravando perigosamente desde o início da crise. A UE e as instituições comunitárias desapareceram de cena. Apesar da situação excepcional que se vive na Europa e do sofrimento dos seus povos, ninguém dá pela existência do Parlamento Europeu, que continua muito longe de ser o órgão representativo dos povos da União Europeia. A Comissão Europeia perdeu a autonomia e o poder de iniciativa. E é claro que nem os povos, nem os parlamentos nacionais são ouvidos quando se trata de decisões importantes.

O normal funcionamento dos órgãos colegiais da UE deu lugar ao que Habermas chama de "intergovernamentalismo dos chefes do euro-clube, que atuam nos bastidores". ${ }^{17}$

16 Cfr. Ulrich BECK, ob. cit., 20/21, 27 e 110.

17 Cfr. ob. cit., 136. 
Com efeito, os 'donos' da Europa resolvem tudo (ou não resolvem nada) à margem das instituições comunitárias (e, sobretudo, dos povos da Europa), no âmbito das relações intergovernamentais, sob a batuta da Alemanha. A igualdade entre os estados-membros, apesar de consagrada nos Tratados, é completamente ignorada, porque tudo é decidido em função dos interesses 'imperiais' e dos calendários eleitorais da Alemanha.

3. Com a vitória da contra-revolução monetarista, em meados da década de 1970, o vírus neoliberal foi sendo inoculado em doses fatais nos sucessivos tratados estruturantes da 'Europa', desde o Ato Único Europeu (1986) ao Tratado de Maastricht (1991), à 'endeusada' Constituição Europeia (assinada pelos Chefes de Estado e de Governo em outubro/2004, e morta depois, de "morte matada", pelos votos de franceses e holandeses), ao chamado Tratado de Lisboa (assinado em dezembro/2007) e ao mais recente Tratado Orçamental (março/2012).

Tudo isto foi possível porque os partidos socialistas europeus escolheram este caminho.

Durante anos, mesmo depois da constituição de alguns partidos comunistas em países da Europa ocidental, os partidos da Internacional Socialista recusaram por várias vezes, nomeadamente na França e na Alemanha, participar em governos da burguesia.

Entretanto, os tempos mudaram, e, como bem sabia o nosso Camões, mudam-se os tempos, mudam-se as vontades... Os socialistas cansaram-se de lutar, fora do aparelho do estado, pelos interesses dos trabalhadores e pela construção do socialismo. Seduzidos pelos encantos do poder, decidiram que era tempo de 'assumir as suas responsabilidades', de 'fazer política a sério', política 'ao mais alto nível'.

Um momento marcante desta 'evolução' foi sem dúvida o Congresso do Partido Social Democrata Alemão (SPD), 
realizado em Bad Godesberg, em 1959, que aprovou o novo programa do partido, no qual não figura qualquer referência a nacionalizações e se proclama que a propriedade privada merece a proteção da sociedade, desde que não impeça a realização da justiça social. ${ }^{18}$

Para quem entenda que o socialismo não pode deixar de incluir, no seu núcleo essencial, a eliminação dos rendimentos não provenientes do trabalho (o que pressupõe a apropriação social dos principais meios de produção), esta opção dos partidos socialistas e sociais-democratas europeus “apenas significa - como sublinhava, há anos, Teixeira Ribeiro ${ }^{19}$ - que tais partidos desistiram de implantar um sistema económico socialista". Na verdade, como o mesmo professor enfatiza, "o socialismo de economia capitalista", "o socialismo dos partidos socialistas (também chamados, em vários países, partidos sociais-democratas e partidos trabalhistas) não se diferencia substancialmente do capitalismo dos partidos capitalistas, uma vez que uns e outros se propõem alcançar em economia capitalista os mesmos objetivos: desenvolvimento económico e justiça social". ${ }^{20}$

Os socialistas e sociais-democratas europeus desfizeram-se da concepção incómoda do estado enquanto estado de classe, resolveram assumir as suas responsabilidades (responsabilidades de estado...) como "gestores leais do capitalismo" e instalaram-se comodamente nesta nova postura, confortados pela sua 'fé' nas virtudes da "concorrência livre e não falseada" e da "economia social de mercado" (ou "economia de

18 Há quem - dentro do campo social-democrata - recue alguns anos, defendendo que "o SPD deixou de ter ambições genuinamente revolucionárias o mais tardar em 1914, se é que de facto alguma vez as teve" (T. JUDT, PÓS-GUERRA, cit., 316).

19 Cfr. J. J.Teixeira Ribeiro, Sobre o Socialismo, cit., 57.

${ }^{20}$ Cfr. últ. ob. cit., 5. 
mercado regulada”), 'aliviados' pela 'crença' de que não há alternativa (Thatcher dixit) ao mercado e ao capitalismo.

A preocupação fundamental dos partidos socialistas e sociais-democratas passou então a ser a de ganhar 'respeitabilidade'. E, talvez convencidos de que, nas condições da época, o respeito pelo deus mercado era uma condição de 'respeitabilidade' política para poderem 'fazer política a sério', proclamaram, com 'grande sentido de estado', a sua 'vocação governamental', a sua disponibilidade e a sua capacidade para 'assumir as suas responsabilidades' de assegurar a gestão leal do capitalismo, sem pôr em causa o próprio sistema.

Nos anos 50 e 60 do século XX os socialistas e sociais-democratas europeus consideravam-se gravemente ofendidos e reagiam violentamente quando, à sua esquerda, comunistas e outros os acusavam de gestores leais do capitalis$m o .{ }^{21}$ Hoje, os equívocos de há meio século desapareceram: a social-democracia europeia não quer mais do que gerir lealmente o capitalismo. A ofensa, agora, é classificá-los como neoliberais, epíteto que eles rejeitam, apesar de ser notória a sua submissão ao neoliberalismo 'codificado' no consenso de Washington (aceitando a 'morte' de Keynes e do consenso keynesiano) e de ser notória a inspiração neoliberal de muitas das políticas que praticam quando têm responsabilidades de governo.

Conscientes do passo que deram, os socialistas europeus procuram passar a ideia de que continuam a ser socialistas, proclamando que são defensores do capitalismo na esfera da

21 Em Portugal, já depois de promulgada a Constituição de 1976, era frequente ouvir-se os seus dirigentes afirmar que, para eles, a social-democracia não era um fim em si mesmo, mas apenas um meio para chegar ao socialismo. Nas paredes e muros viam-se inscrições como estas: "PPD - Pela Democracia e pelo Socialismo". E o PPD (hoje PPD/PSD) não era (nem é) membro da Internacional Socialista. 
produção, mas são socialistas no que toca à distribuição do rendimento.

Para além da contradição nos termos (como pode ser socialista quem defende o capitalismo como modo de produção?), creio que esta doutrina social-democrata representa uma equação teórica e política tão difícil de resolver como a da quadratura do círculo. Com efeito, sabemos, desde os fisiocratas, que as estruturas de distribuição do rendimento e da riqueza não podem considerar-se separadas das estruturas e das relações sociais da produção. Por outras palavras: a estrutura de classes da sociedade e as relações de produção que lhe são inerentes são os fatores determinantes da distribuição da riqueza e do rendimento. A lógica da distribuição não pode ser antagónica da lógica inerente às relações de produção capitalistas. Como é óbvio, não se pode defender o capitalismo na esfera da produção e o socialismo na esfera da distribuição.

Prosseguindo um processo iniciado em finais do século XIX, o movimento social-democrata abandonou também, em meados do século passado, a tese de que o estado é sempre, nas sociedades de classes, um estado de classe, deixando para trás não só Marx, mas os grandes clássicos do século XVIII. Basta recordar os fisiocratas, para quem o estado era o estado dos proprietários. E recordar Adam Smith: o estado foi instituído logo que surgiram (e porque surgiram) "propriedades valiosas e vastas"; foi "instituído com vista à segurança da propriedade", com vista "à defesa dos ricos em prejuízo dos pobres"; foi instituído para garantir aquele "grau de autoridade e subordinação" sem o qual não é possível manter o status quo.

Como salienta um dos seus teóricos em Portugal, a "esquerda democrática" "mudou radicalmente de atitude face ao estado", ao longo do século XX: abandonou a "posição libertária de querer destruí-lo [ao estado capitalista], como 
dominação e fator de dominação burguesa" e proclamou uma mudança na "arquitetura institucional do estado", transformando-o em um "espaço de integração social e intervenção política para as organizações vinculadas ao movimento operário". No novo programa do socialismo reformista o estado (o estado capitalista, porque é dele que estamos a falar) passou a ser considerado como "comunidade política nacional", como "espaço de pertença de toda a coletividade", como "expressão da comunidade política nacional", como "representação política de toda a sociedade". ${ }^{22}$

Segundo este modo de ver, o estado seria algo parecido com um clube onde todos os cidadãos poderiam entrar, se para isso tivessem os votos suficientes dos cidadãos-eleitores. Sem querer analisar aqui a questão do condicionamento das votações pela ideologia dominante, cuja produção é rigorosamente controlada pelo núcleo duro das classes dominantes ${ }^{23}$, lembrarei apenas o que se passa na "grande democracia americana": há décadas que vêm sendo eleitos para a Presidência dos EUA os candidatos que conseguem reunir mais fundos para a campanha eleitoral, sendo público que esses fundos provêm, em larguíssima medida, do Big Business. ${ }^{24}$

22 As transcrições são de Augusto Santos Silva, ob. cit., 22, 32-34, 38.

23 No entanto, como é sabido, foi a consciência disto mesmo que, a certa altura, levou a burguesia dominante a deixar de ver no sufrágio universal uma ameaça de revolução permanente, passando a considerá-lo um instrumento de integração, de anestesia e de prevenção da contestação revolucionária. Alguns, à direita, chegam a defender o voto obrigatório (o voto pela arreata).

${ }^{24}$ Os dados divulgados relativamente às eleições realizadas nos EUA em novembro/2012 fazem destas eleições as mais caras da história: seis mil milhões de dólares, a maior parte provenientes de empresas e de "grupos de cidadãos" abrigados em Comités de Ação Política (Super $P A C$ 's). Agências especializadas estimam que 91 pessoas terão adiantado $60,5 \%$ destas verbas, sendo $25 \%$ delas de origem incerta. As eleições 
americanas são um negócio escuro, sem o mínimo de transparência. Cfr. Avante, 8.11.2012.

As mesmas agências calculam que a contribuição destas Super PAC's aumentou 400\% desde 2008, por efeito de uma decisão do Supremo Tribunal Federal dos EUA (janeiro/2010) que veio impedir a limitação das verbas angariadas através deste expediente. Invocando a liberdade de expressão, o STF veio autorizar as empresas e os lobbistas a aumentar sem restrições as suas contribuições financeiras para apoiar as campanhas eleitorais dos 'seus' candidatos (nas últimas eleições presidenciais, calcula-se que $80 \%$ dos 'donativos' foram feitos por 200 'doadores' muito ricos). Tudo em nome da "liberdade de expressão"! Pois bem. Reagindo a esta "completa legitimação da corrupção ilimitada", um grupo de cidadãos pôs a circular uma petição solicitando aos dirigentes de todos os estados americanos que emendem a Constituição dos EUA, "a fim de declarar expressamente que as multinacionais não são o povo, que elas não têm os mesmos direitos que o povo e que o dinheiro não constitui uma forma de liberdade de expressão". E a verdade é que, mesmo num país como os EUA, em fevereiro/2012, o texto já tinha obtido a aprovação de centenas de conselhos municipais (incluindo os de Los Angeles e Nova Iorque) e do Senado do Novo México. Informações colhidas em Le Monde Diplomatique, ed. port., abril/2012 e em J. Stiglitz, O Preço..., cit., 16, 20, 42, 44, 111, 191ss, 203-214, 416.

Este 'negócio eleitoral' (o financiamento dos partidos e das campanhas eleitorias) é o caldo de cultura onde nasce e se desenvolve a grande corrupção, que se vem confirmando como uma doença sistémica das sociedades capitalistas. A corrupção por esta via é potenciada nos países de regime presidencialista e naqueles cujos sistemas eleitorais assentam nos círculos que elegem um só deputado ou que permitem que, de entre os candidatos do mesmo partido, sejam eleitos os mais votados (porque, nestes casos, não são apenas os partidos que lutam uns contra os outros, são também os candidatos de cada partido a lutar uns contra os outros).

Não admira, por isso, que o sistema político dos EUA assente cada vez mais, como sublinha Joseph Stiglitz, no princípio "um dólar, um voto", passando à história o princípio democrático "uma pessoa, um voto". E, se é certo que "os mercados são modelados pela política”, porque "as políticas determinam as regras do jogo económico", não é menos certo que, nos países capitalistas, "o campo do jogo está inclinado para os 1\% do topo", porque "as regras do jogo político também são moldadas por esses 1\%”. O Prémio Nobel da Economia de 2001 conhe- 


\section{É óbvio que nenhum candidato ou nenhum partido que se apresente como representante dos interesses dos tra- balhadores consegue entrar neste estado-para-todos, porque é}

ce bem o sistema por dentro (ele foi economista-chefe do Banco Mundial e Presidente do Conselho de Assessores Económicos do Presidente Clinton), e não tem dúvidas em afirmar que "os mercados financeiros conseguem o que querem. Podem existir eleições livres, mas, dado o modo como são apresentadas aos eleitores, não existe uma verdadeira escolha nas questões que realmente interessam, as questões da economia".

Sem utilizar as categorias e a linguagem do marxismo, o último livro de J. Stiglitz deixa muito claro que o estado capitalista é hoje a ditadura do grande capital financeiro, uma ditadura de rendistas, que recorrem sistematicamente a práticas que classifica de "depravação moral” (é o que venho designando por capitalismo do crime sistémico). O 'sistema' recorre, aliás, a expedientes vários para afastar os pobres do sufrágio eleitoral. Nos últimos anos, as eleições presidenciais nos EUA não têm mobilizado mais do que $57 \%$ dos eleitores, e a afluência às urnas nas eleições para o Congresso não vai além de $37,5 \%$, sendo de salientar que só $20 \%$ dos jovens exercem o direito de voto. É uma falsa democracia, que não tem a confiança dos cidadãos eleitores, uma 'democracia' em que os 'representantes do povo’ são pagos pelo grande capital (que financia os custos obscenos das campanhas eleitorais - nas últimas eleições realizadas nos EUA, Democratas e Republicanos receberam do $1 \%$ mais rico a parte de leão dos milhares de milhões de dólares que gastaram na campanha), são eleitos pelos ricos e usam os seus poderes para moldar o sistema económico em benefício dos muito ricos, dos que vivem de rendas (rendas monopolistas, rendas da corrupção, rendas da fraude fiscal e de outras práticas criminosas, como a lavagem de dinheiro sujo, para além das rendas legais, oferecidas e protegidas pela legislação aprovada 'democraticamente' no Congresso). Para garantir estas votações 'democráticas', só os grandes do sistema financeiro mantêm ao seu serviço, em permanência, um lobbista por cada dois membros do Congresso, sabendo-se que, em momentos especiais, quando estão em causa leis importantes, chegam a mobilizar um exército de lobbistas cinco vezes superior aos membros do Congresso. Nesta guerra de classes, a violência não tem limites: esta ditadura não tem nada que ver com a democracia real.Ver, em especial, o cap. 2 (Rent-seeking e a formação de uma sociedade desigual) e o cap. 4 (Democracia em perigo) do livro de Joseph Stiglitz. 
o dinheiro que comanda e garante a eleição do Presidente e a eleição dos Representantes e dos Senadores. E todos sabemos que não há almoços grátis... O direito a participar no estado transformou-se num 'bem' que tem de se 'comprar' no mercado, e este 'mercado', como todos os outros, é controlado pelo grande capital. Como em todos os mercados, também neste 'mercado dos votos' a soberania do cidadão não passa de pura fantasia. ${ }^{25}$

Esta teoria do estado como "representação política de toda a sociedade", se não é a negação da existência de classes sociais, é, pelo menos, a defesa da colaboração de classes no seio de um estado que se assume como a "representação política de toda a sociedade". Assim como "a sociedade" substitui as classes, também o estado se apresenta como uma entidade (uma espécie de 'árbitro') acima das classes e dos interesses de classe. Foi esta visão da sociedade e do estado que abriu caminho ao 'compromisso' da concertação social entre parceiros sociais, com o estado, neutro, acima das classes (substituídas pelos parceiros sociais) a arbitrar a concertação, em busca do bem comum (a bem da nação...).

Na minha perspetiva, esta concepção da sociedade e do estado é uma das razões que facilitou o envenenamento da social-democracia europeia pelo neoliberalismo (cuja 'filosofia' alimentou todo o processo de construção europeia), tornando-a incapaz de fazer a crítica deste capitalismo da era da globalização neoliberal, sob a invocação de que não há alter-

25 Esta questão é, aliás, tão antiga como as eleições nas sociedades capitalistas. Por volta de 1832, um candidato ao Parlamento britânico calculava ter de gastar, numa única eleição, entre dez mil e vinte mil libras (uma fortuna!). E numa publicação da época escrevia-se: "Não há no reino meia dúzia de localidades em que um homem honesto, de competência e de caráter reconhecidos possa esperar vencer outro que esteja preparado para despender uma fortuna para o conseguir" (informação colhida em Morton/TATe, ob. cit., 80/81). 
nativa, 'argumento' irracional, ofensivo da nossa inteligência e da nossa liberdade, que tem alimentado a cultura do medo difundida nos grandes meios de comunicação social pelos defensores da inevitabilidade das políticas (políticas do capitalismo de casino e do crime sistémico) que conduziram à crise, pelos defensores das políticas de austeridade, absurdas e suicidas, que estão a agravar a crise, pelos defensores da inevitabilidade da globalização neoliberal e da inevitabilidade do fim do estado social.

Não posso partilhar esta visão do estado, sobretudo um tempo, como aquele que vivemos, em que a atuação do estado capitalista como estado de classe se afirma, todos os dias, aos olhos de toda a gente que não fecha os olhos à realidade. A predominância do grande capital financeiro traduz-se no sacrifício não só dos direitos que os trabalhadores e as suas organizações foram conquistando ao longo de séculos de lutas, mas também dos interesses de grandes camadas da pequena e média burguesia ligada às atividades produtivas.

E não posso esquecer que o estado capitalista já foi estado liberal (negando, durante longo tempo, a liberdade de organização dos trabalhadores em sindicatos e o sufrágio universal, ou suspendendo-o quando lhe convinha), foi estado fascista, foi estado social, do mesmo modo que agora é estado regulador ou estado garantidor, asfixiando e esvaziando o estado social, sacrificado à garantia das rendas (verdadeiras rendas feudais) do grande capital financeiro, único beneficiário deste recentíssimo capitalismo do crime sistémico, capitalismo sem risco e sem falências.

4. A ideologia neoliberal parece apontar para a redução do estado a uma espécie de estado mínimo. Mas o neoliberalismo não pode confundir-se com o regresso ao laisser-faire e aos 'mercados livres', que dispensam a 'intervenção' do estado na economia. 
Enquanto ideologia que visa reverter em sentido favorável ao grande capital financeiro a correlação de forças entre o capital e o trabalho, o neoliberalismo, ao contrário do que por vezes se quer fazer crer, não é uma ideologia libertária, que dispensa o estado. Nas sociedades de classes em que vivemos, o capitalismo pressupõe sempre a existência do estado capitalista. E o neoliberalismo e o projeto político por ele veiculado exige, como todos podemos observar nos tempos que correm, um forte estado de classe, capaz de prosseguir objetivos ambiciosos.

Num livro de 1994, Andrew Gamble mostrou isto mesmo, com base na análise da experiência do thatcherismo: "a Nova Direita acredita que para salvar a sociedade livre e a economia livre é necessário restaurar a autoridade do estado. (...) A doutrina-chave da Nova Direita e do projeto político que ela inspirou é a economia livre e o estado forte", capaz de "restaurar a autoridade a todos os níveis da sociedade" e dar combate aos inimigos externos ("enemies without") e aos inimigos internos ("enemies within”). ${ }^{26}$

Foram as instituições do poder político (o poder político de classe, a ditadura do grande capital financeiro: os estados nacionais e as organizações internacionais dominadas pelo capital financeiro e pelos seus estados) que construíram, pedra a pedra, o império do capitalismo neoliberal (o capitalismo de casino, o capitalismo sem risco e sem falências, o capitalismo do crime sistémico), assente nos seguintes pilares: liberdade absoluta de circulação de capitais à escala mundial (a 'mãe' de todas as liberdades do capital); desregulação de todos os mercados (em especial os mercados financeiros, entregues ao "dinheiro organizado" comandado pelos especuladores, os 'padrinhos' do crime sistémico, a sida da economia mundial); imposição do dogma da independência dos bancos centrais, que se traduziu na 'privatização'

${ }^{26}$ Ver A. Gamble, The Free Economy..., cit. 35 e 63-68 (todo o capítulo 2). 
dos estados nacionais, dependentes dos "mercados" (como as famílias ou as empresas) para o seu próprio financiamento (para o financiamento das políticas públicas); privatização do setor público empresarial, incluindo os serviços públicos (até a água!) e as empresas estratégicas que são o verdadeiro suporte da soberania nacional; aplicação de sistemas fiscais que favorecem os ricos e sufocam os pobres.

Só um estado forte poderia ter criado as condições que permitiram dispensar o compromisso dos tempos do estado social keynesiano, substituindo-o pela violência do estado neoliberal (estado regulador e estado garantidor), que se vem abatendo sobre os trabalhadores, com o objetivo de transferir para o capital os ganhos da produtividade, violência que se tem traduzido: no desmantelamento do estado social e no 'confisco' dos direitos económicos, sociais e culturais dos trabalhadores (que muitas constituições consagram como direitos fundamentais dos trabalhadores); na desregulamentação das relações laborais; na 'guerra' contra os sindicatos ${ }^{27}$; no esvaziamento da contratação coletiva (que mostrou ser, como a OIT evidenciou, um instrumento de redistribuição do rendimento em sentido favorável aos trabalhadores mais eficaz do que as políticas de redistribuição de inspiração keynesiana). ${ }^{28}$

${ }^{27}$ A política anti-sindical foi iniciada, no Reino Unido, no início da década de 1960, pelo governo trabalhista de Harold Wilson, tendo prosseguido com o governo conservador de Edward Heath e depois com os governos trabalhistas de Harold Wilson e de James Callaghan, dez anos antes da era Thatcher, que lhe acrescentou o verniz e a violência neoliberais. (Cfr. I. MészÁros, O Século XX, cit., 95). Mas esta guerra contra os

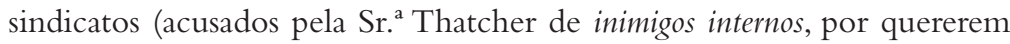
"destruir o estado") ganhou novo fôlego no final da década de 1970 (por alturas da 2. ${ }^{a}$ crise do petróleo), sendo os seus episódios mais dramáticos a destruição do sindicato dos controladores aéreos pela Administração Reagan (1981) e a vitória do Governo Thatcher sobre o lendário sindicato dos mineiros britânico (1984).

28 Também neste plano cai a máscara do compromisso e da ambiguidade que lhe é inerente. O Direito do Trabalho, muitas vezes apresentado 
como Direito dos Trabalhadores (porque inspirado no princípio do favor laboratoris, na proteção da parte mais fraca na relação contratual entre capitalistas e trabalhadores) ou até como "direito contra a exploração", assume cada vez mais a sua verdadeira face de Direito dos Empresários. A verdade é que ele sempre "prometeu o que, por óbvio, não poderia (nem queria) cumprir", porque, nas sociedades de classes, nas quais, "mesmo diante da proteção pelo direito, o poder está realmente nas mãos do capital", a sua função sempre foi a de "reproduzir (função de reprodução), de ocultar a exploração do trabalho não pago (função de ocultação) e de mascarar a insuportável desigualdade decorrente de uma relação de poder/sujeição" (Ver Aldacy CoutinHo, ob. cit., 167-180).

O Direito do Trabalho sempre foi, com efeito, um direito criado pelo estado capitalista e este não é um estado acima das classes, mas um estado de classe, cuja função é a de garantir as condições de funcionamento do modo de produção capitalista, que não pode subsistir, como sublinha a Autora atrás referida, "sem divisão entre proprietários e não proprietários, sem exploração do trabalho alheio, sem tomada da mais-valia, sem instaurar uma relação de poder/dominação/disciplina-sujeição/obediência”. Esta é também a função do estado e do Direito do Trabalho nas sociedades capitalistas. Já Adam Smith pusera em realce (Riqueza das Nações, II, 321/322) que, com o aparecimento da desigualdade de fortuna, "foi introduzido no seio dos homens um grau de autoridade e subordinação anteriormente impossível de existir", e, com este, "o governo civil indispensável à manutenção e consolidação dessa autoridade e subordinação", constituindo os ricos (...) "uma espécie de aristocracia que tem todo o interesse em defender a propriedade e em apoiar a autoridade do seu soberano a fim de este poder defender a sua própria propriedade e apoiar a sua autoridade".

Adam Smith revela já uma clara compreensão da natureza do salário nas relações capitalistas de produção e do enquadramento jurídico do 'contrato de trabalho', quando ensina que "os salários correntes do trabalho dependem, por toda a parte, de contrato habitualmente celebrado entre duas partes, cujos interesses não são de modo algum idênticos".

Mas o pai fundador do liberalismo vai mais longe na desmitificação do 'contratualismo', quando defende que o 'contrato de trabalho' não é um contrato como os outros, porque as duas partes que intervêm neste 'contrato' não estão nele em posição de igualdade, pois os trabalhadores não são livres de contratar ou não contratar, uma vez que "vivem dos salários", por não terem nada de seu além da "sua força e habilidade de mãos", o que significa que são economicamente (não juridicamente) 
Em livro recente, Wolfgang Streek analisa criticamente o processo em curso de esvaziamento da democracia como "uma imunização do mercado a correções democráticas". $\mathrm{Na}$ sua ótica, esta imunização pode ser levada a cabo "através da abolição da democracia segundo o modelo chileno dos anos 1970" [opção que entende não estar disponível atualmente], ou então "através de uma reeducação neoliberal dos cidadãos" [promovida pelo que designa "relações públicas capitalistas", as grandes centrais de produção e difusão da ideologia neoliberal].

obrigados a trabalhar: "Um proprietário, um rendeiro, um dono de uma fábrica, ou um comerciante - escreve Smith - poderiam normalmente subsistir um ou dois anos sem empregar um único trabalhador, com base no pecúlio previamente acumulado. Muitos trabalhadores não conseguiriam subsistir uma semana, poucos subsistiriam um mês, e praticamente nenhum sobreviveria um ano sem emprego. A longo prazo, o operário pode ser tão necessário ao patrão como o patrão lhe é necessário a ele, mas a necessidade não é tão imediata".

Nestas condições, observa o filósofo e economista escocês, "não é dificil prever qual das partes, em circunstâncias normais, levará sempre a melhor nesta disputa [a disputa entre os operários que "pretendem obter o máximo possível" e os patrões que "procuram pagar-lhes o mínimo possível"] e obrigará a outra a aceitar os seus próprios termos" (Cfr. Riqueza das Nações, I, 176-178).

Mais tarde, foi a vez de Marx esclarecer (Salário, Preço e Lucro) que, no sistema do trabalho assalariado, "mesmo o trabalho não pago parece ser trabalho pago", sendo a natureza da relação laboral "totalmente dissimulada pela intervenção do contrato e pelo pagamento efetuado" pelo empregador: é "esta falsa aparência que distingue o trabalho assalariado das outras formas históricas do trabalho". No contexto da nova ordem jurídica burguesa, o contrato de trabalho constitui, pois, um expediente que permite esconder a mais-valia (o trabalho não pago, que, nas condições do feudalismo, era tão facilmente identificado) e a exploração inerente ao modo de produção capitalista assente no trabalho assalariado, dando a entender que o salário é o pagamento correspondente ao valor do trabalho (ao valor criado pelo trabalhador assalariado). 
E logo explicita quais os caminhos que estão a ser percorridos para conseguir "a eliminação da tensão entre capitalismo e democracia, assim como a consagração de um primado duradouro do mercado sobre a política" [os itálicos são meus. AN]: «'reformas' das instituições político-económicas, através da transição para uma política económica baseada num conjunto de regras, para bancos centrais independentes e para uma política orçamental imune aos resultados eleitorais; através da transferência das decisões político-económicas para autoridades reguladoras e para grupos de 'peritos', assim como dos travões ao endividamento consagrados nas constituições, aos quais os estados e as suas políticas se devem vincular juridicamente durante décadas, se não para sempre".

O "primado duradouro do mercado sobre a política" passa ainda por outros caminhos: "os estados do capitalismo avançado devem ser reestruturados de forma a merecerem duradouramente a confiança dos detentores e dos gestores do capital, garantindo, de forma credível, através de programas políticos consagrados institucionalmente, que não irão intervir na 'economia' - ou, caso intervenham, que só irão fazê-lo para impor e defender a justiça de mercado na forma de uma remuneração adequada dos investimentos de capitais. Para tal - conclui o autor -, é necessário neutralizar a democracia, entendida no sentido da democracia social do capitalismo democrático do período pós-guerra, assim como levar por diante e concluir a liberalização no sentido da liberalização hayekiana, isto é, como imunização do capitalismo contra intervenções da democracia de massas".

Tem razão Wolgang Streeck quando recorda que "já ficou várias vezes demonstrado que o neoliberalismo necessita de um estado forte que consiga travar as exigências sociais e, em especial, sindicais de interferência no livre jogo das forças do mercado. (...) O neoliberalismo não é compatível com um estado democrático, se entendermos por democracia um 
regime que intervém, em nome dos seus cidadãos e através do poder público, na distribuição dos bens económicos resultantes do funcionamento do mercado". ${ }^{29}$

É uma longa transcrição, que me pareceu pertinente registar aqui, porque vejo nela a síntese de pontos de vista que venho defendendo há anos em outros escritos.

A reflexão de Wolfgang Streeck ajuda-nos a perceber o que está em causa quando as vozes 'dominantes' falam de reformas estruturais, de regras de ouro, da independência dos bancos centrais, da reforma do estado, de finanças sãs, da necessária reforma do estado social, do papel insubstituível das agências reguladoras independentes, dos beneficios da concertação social, da flexibilização do mercado de trabalho, da necessidade de 'libertar' a ação política do controlo do Tribunal Constitucional.

E alerta-nos também para outro ponto: estas soluções 'brandas' (apesar de 'musculadas' e até violentas) só serão prosseguidas se "o modelo chileno dos anos 1970" não ficar disponível para o grande capital financeiro. Se as condições o permitirem (ou o impuserem, por não ser possível continuar o aprofundamento da exploração dos trabalhadores através dos referidos métodos 'reformistas' do "capitalismo democrático do pós-guerra”), o estado capitalista pode vestir-se e armar-se de novo como estado fascista, sem as máscaras que atualmente utiliza.

5. Desfeita, no início da década de 70 do século XX, a miragem do capitalismo sem crises saído da 'revolução keynesiana', o triunfo da "contra-revolução monetarista" e dos dogmas neoliberais significou, em certos aspetos, o regresso ao século XIX. E o estado capitalista cumpriu o seu papel nas condições históricas das últimas três ou quatro décadas.

Após o desmoronamento da União Soviética e da comunidade socialista, os neoliberais de todos os matizes

${ }^{29}$ Cfr. W. Streeck, ob. cit., 59-66 e 91-105. 
convenceram-se, mais uma vez, de que o capitalismo tinha garantida a eternidade, podendo permitir todas as liberdades ao capital e esvaziar todos os direitos dos trabalhadores. Foi o reino do pensamento único e do deus-mercado. Foi a assunção (sem disfarce) do capitalismo como a civilização das desigualdades. Foi o regabofe do capitalismo de casino, arrastando consigo a praga do crime sistémico e os perigos inerentes ao fascismo amigável (Bertram Gross) e ao fascismo de mercado (Paul Samuelson).

Teoricamente, pode falar-se - com acerto - de substituição da política pelo mercado, ou de morte da política, tal como a entendemos. Mas pode dizer-se também que, em certo sentido, esta é uma outra forma de fazer política, porque, tal como o estado, o mercado é uma instituição política.

É esta a lição da História. Por isso se diz que o marginalismo se apresenta como uma perspetiva a-histórica, que dificilmente pode apreender e compreender a realidade social. Foi esta perpetiva que levou os marginalistas a centrar o objeto de estudo da ciência económica na análise do comportamento do homo oeconomicus, um homem inventado, que se pressupõe obedecer sempre aos mesmos princípios de racionalidade, independentemente da sua inserção na história e da sua inserção social, e que atua através de atos de escolha efetuados de acordo com a mesma lógica operativa, informados por um critério universal e intemporal de racionalidade económica, quer se trate de Robinson na sua ilha, de um produtor ou de um comprador, de um trabalhador assalariado ou do seu empregador capitalista, de uma pequena mercearia de bairro pobre ou de um poderoso conglomerado transnacional.

Trata-se de apresentar o princípio de racionalidade (o cálculo económico) como "um dado invariante da natureza humana, como um facto quotidiano e banal da experiência, que 
remete para um a priori não histórico ou trans-histórico". ${ }^{30}$ Mas - insisto - esta visão da sociedade e da economia ignora o que a história nos ensina: longe de ser um dado invariante da natureza humana, aquele princípio é o produto de um longo processo de desenvolvimento histórico das relações de produção, que culminou com o advento do capitalismo como modo de produção autónomo. O que quer dizer que o mercado não é um mecanismo natural de regulação automática da economia: surgiu em determinadas condições históricas, quando, com a desagregação da sociedade feudal (e do modo de produção feudal), as empresas substituíram as famílias como unidades de produção por excelência e o móbil da produção deixou de ser o que era próprio da economia doméstica anterior (a satisfação das necessidades das pessoas ou das famílias) e passou a ser o da maximização do lucro.

Nas épocas anteriores à civilização capitalista, "no centro de todo o esforço e preocupação estava o homem, medida de todas as coisas" (Werner Sombart). Nesta fase da 'economia natural' são múltiplos os fins da atividade económica, que se desenvolve segundo critérios costumeiros, tradicionais.

Com o desenvolvimento da produção de mercadorias para vender no mercado (que Marx sintetizou na fórmula D-M-D'), a atividade produtiva (distinta da atividade para a economia doméstica) passa a prosseguir um objetivo homogéneo, quantificável e mensurável, o ganho monetário. Sendo uma grandeza monetária, este ganho é comparável com os custos de produção (D pode comparar-se com D'). Nasce, historicamente, a categoria do lucro capitalista. O homem natural foi substituído (como diria Sombart) pelo homem capitalista, que "busca o lucro racional e sistematicamente" (Max Weber). E, sobretudo, surgiu a empresa capitalista como

${ }^{30}$ Cfr. M. Godelier, ob. cit. 
realidade separada da economia doméstica do seu proprietário, o que aconteceu, fundamentalmente, com o desenvolvimento das sociedades comerciais e, acima de todas, as sociedades anónimas.

Só então se realizaram as condições indispensáveis para a aplicação plena do princípio da racionalidade económica, que corresponde a um certo estádio de desenvolvimento das relações de produção. Para a empresa capitalista, a maximização do lucro é o único objetivo a prosseguir e a adoção dos princípios do cálculo económico é uma exigência vital para evitar o perigo último da concorrência entre as empresas (a falência) e para conseguir aquele objetivo. Como Marx observou, o princípio da racionalidade económica surge como "uma força inerente ao capital e como um método próprio e caraterístico do modo de produção capitalista".

A esta luz, o mercado é, como o estado, uma instituição social, um produto da história, uma criação histórica da humanidade (correspondente a determinadas circunstâncias económicas, sociais, políticas e ideológicas), que veio servir (e serve) os interesses de uns (mas não os interesses de todos), uma instituição política destinada a regular e a manter determinadas estruturas de poder que asseguram a prevalência dos interesses de certos grupos sociais sobre os interesses de outros grupos sociais. É neste sentido que David Miliband defende que, "longe de serem 'naturais', os mercados são políticos". ${ }^{31}$ Quer dizer: o mercado e o estado são ambos instituições sociais, sendo que o estado capitalista e o mercado surgiram em determinadas condições históricas, de tal modo ligados que um pressupõe o outro e cada um vai moldando o outro.

31 Cfr. D. Miliband, ob. cit.. Num artigo de 1996, que intitula "Markets as Politics", Neil Fligstein (ob. cit.) mostra a estreita ligação entre estado e mercado nas sociedades capitalistas, evidenciando o papel essencial do estado na construção das instituições do mercado enquanto "construções sociais". 
Do ponto de vista jurídico, poderemos dizer, com Eros Grau, que "o mercado é uma instituição jurídica constituída pelo direito positivo, o direito posto pelo Estado moderno" [o Estado burguês, o Estado capitalista, o Estado que surgiu na Europa "quase concomitantemente com o mercado capitalista e o cálculo económico"].

Para além de constituir o mercado, o Estado garante a liberdade económica e regulamenta [regula] o mercado. Esta função de regulação é, desde os primeiros tempos do capitalismo, a função essencial do direito burguês, enquanto instrumento de "dominação da sociedade civil pelo mercado", "domesticando' os determinismos económicos e garantindo a fluidez da circulação de mercadorias, nomeadamente através do direito dos contratos, que visa assegurar um elevado grau de certeza quanto ao seu cumprimento, grau de certeza indispensável ao cálculo económico.

E se a "plena auto-regulação do mercado é inconcebível”, a sua regulação pelo Estado (pelo direito positivo) faz do mercado "um signo que conota um projeto político, um princípio de organização social”.

$\mathrm{Na}$ síntese lapidar de Eros Grau, "ambos, estado e mercado, são espaços ocupados pelo poder social, entendido o poder político como uma forma sua. Mercado e Estado não apenas coexistem, são interdependentes, construindo-se e reformando-se no processo da sua interação". ${ }^{32}$

32 Cfr. E. Grau, "O Estado..., cit., 25-29. Entendido o mercado nestes termos, ele é dificilmente compatível com uma verdadeira democracia. Os defensores das virtudes do mercado sustentam, porém, que, dando a todos iguais possibilidades de participar na orientação da vida económica, o mercado é a base de um autêntico governo democrático da economia, indo alguns ao extremo de afirmar que "a economia de livre empresa é a outra face da democracia": "nesta grande e contínua eleição geral da economia livre, ninguém, nem mesmo o mais pobre, é privado do seu direito de voto: estamos todos a votar a todo o momento" (Enoch Powel). 
Tanto basta para ficar claro que a defesa do mercado como mecanismo de regulação automática da economia, por oposição à presença do estado na economia e à regulação da economia pelo estado, não representa apenas um ponto de vista técnico sobre um problema técnico.

Em boa verdade, a defesa do mercado é a defesa do modelo (da concepção filosófica) liberal da economia e da sociedade, que assenta no mercado enquanto mecanismo pretensamente capaz de uma arbitragem 'neutral' dos conflitos de interesses, uma instituição que garante a distribuição 'natural' dos rendimentos entre o capital e o trabalho, uma instituição que, segundo Hayek, "não pode ser justa nem injusta, porque os resultados não são planeados nem previstos e dependem de uma multidão de circunstâncias que não são conhecidas, na sua totalidade, por quem quer que seja". ${ }^{33}$

Esta 'leitura' do significado da 'votação' efetuada no mercado não resiste, no entanto, ao argumento segundo o qual ela 'esquece' o facto essencial de que no mercado se efetua "uma eleição em que alguns eleitores podem votar mais do que uma vez", porque, no mercado livre, o peso (a influência) do voto de cada consumidor depende do que cada um gasta no mercado, o que, por sua vez, depende da riqueza e do rendimento de cada um (Mark Blaug).

E se não houver uma 'justificação moral' para as diferenças de rendimento e para a diferença de natureza do rendimento do trabalho e do rendimento do capital, é inevitável a conclusão de que a 'votação' do mercado está viciada à partida e conduz a resultados injustos, que refletem e ajudam a perpetuar as estruturas (de poder) que geram e mantêm as diferenças de rendimentos. Esta conclusão será ainda mais evidente quando se toma em consideração a riqueza herdada por alguns e o rendimento que dela resulta para os seus titulares pelo simples facto de o serem.

${ }^{33}$ Cfr. F. HAYeк, "The Use..., cit. Uma vez instalada como classe dominante, a burguesia passou a considerar as relações de produção capitalistas como algo de definitivo, inalterável e indiscutível (o capitalismo é o fim da história) e a economia política burguesa voltou as costas à orientação da Economia Política dos clássicos ingleses - que fazia do estudo das relações de produção o objeto principal da sua análise - e ignorou 
deliberadamente a Economia Política marxista, que faz das relações de produção o elemento essencial de cada modo de produção.

Morto o interesse pelo estudo das relações sociais de produção, a atenção da Economia Política burguesa passou a concentrar-se na problemática da formação dos preços no mercado (problemática a que se reduz, a partir de Say, toda a teoria da distribuição do rendimento). A este respeito, é elucidativa a noção de Economia Pura (por oposição à Economia Política clássica) defendida por Walras: “a Economia Pura é, na sua essência, a teoria da determinação dos preços nas condições de um hipotético regime de concorrência livre e perfeita". [sublinhado meu.AN]

Tanto em Ricardo como em Marx, a distribuição do rendimento aparece num 'momento' anterior ao da troca. Os fatores determinantes da distribuição do rendimento baseiam-se nas condições da produção (no poder relativo das várias classes sociais) e a teoria da distribuição tem como pano de fundo as relações sociais de produção (verificadas no contexto de uma sociedade com uma determinada estrutura de classes), por se entender desde os fisiocratas - que o modo de produção (o processo social de produção) do que Engels chamou os "meios materiais de subsistência da sociedade humana" condiciona a distribuição e o destino do produto líquido.

Nesta ótica, a atribuição de lucros - quer se trate dos lucros normais (da concorrência perfeita), quer se trate dos lucros de monopólio - não é uma troca, porque não há nenhum fluxo no circuito real que justifique o fluxo dos lucros no circuito monetário.

Quer dizer: o fluxo da força de trabalho é o único fluxo real que alimenta a atividade produtiva e origina o produto social líquido (cujo valor pode analisar-se em termos de trabalho). E como nem toda a receita resultante da venda do produto total vai ser distribuída em salários, isto significa que também o pagamento de salários não é uma troca (não é uma troca de equivalentes; é, quando muito, uma troca desigual). Em suma: o problema da distribuição do rendimento não pode explicar-se no âmbito das relações de troca; só pode entender-se no quadro definido pelas relações sociais de produção, tendo em conta as relações de poder, sempre presentes nas sociedades de classes.

Diferentemente, para a economia marginalista dominante, a problemática da distribuição esgota-se, na teoria marginalista, na esfera da troca: ela reduz-se à questão da formação dos preços de mercado dos 'serviços produtivos' fornecidos pelos titulares dos fatores de produção, e esta é apenas uma parte do processo mais vasto de formação dos preços em mercados de concorrência. Tal como escrevera Edgworth: "A distribuição é a espé- 
Hayek entende que só faria sentido falar de justiça ou injustiça acerca da distribuição dos benefícios e dos ónus operada pelos mecanismos do mercado se essa distribuição fosse o resultado da ação deliberada de alguma pessoa ou grupo de pessoas, o que não é o caso (pressupondo sempre, é claro, que os mercados são mercados de concorrência perfeita, apesar de todos sabermos que tais mercados nunca existiram e nunca hão-de existir).

O filósofo austríaco fala da "miragem da justiça social"34 e defende que a expressão justiça social deveria ser abolida da linguagem dos economistas (e de todas as pessoas de bem, por certo...): “a expressão 'justiça social' não é, como a maioria das pessoas provavelmente sente - escreve ele -, uma expressão inocente de boa vontade para com os menos afortunados, (...) tendo-se transformado numa insinuação desonesta de que se deve concordar com as exigências de alguns interesses específicos que não oferecem para tanto qualquer razão autêntica". ${ }^{35}$

cie de troca pela qual o produto é dividido entre as partes que contribuíram para a sua produção". E como as trocas são sempre trocas de equivalentes, fica afastada a hipótese de um qualquer excedente por 'justificar', fica excluída qualquer forma de exploração.

Como se vê, os marginalistas tiveram de assumir que a produção é uma troca e que a ciência económica (que eles reduzem a uma ciência das relações de troca) se aplica àquela "troca que chamamos produção" (na expressão de Walras). E a solução encontrada para a problemática da distribuição do rendimento foi condensada na chamada teoria da produtividade marginal (que 'fecha' a teia ideológica do marginalismo): funcionando a economia de acordo com as regras da concorrência perfeita, cada proprietário de qualquer um dos fatores de produção utilizados receberá uma parte do rendimento global exatamente proporcional à sua contribuição para o produto social, o qual se esgotará na soma dos salários, rendas e juros, sem possibilidade de subsistir qualquer excedente.

${ }^{34}$ Ver The Mirage of Social Justice, cit.

35 Apud D. Green, ob. cit., 127. Robert Nozick e outros desenvolvem a tese de que não há fundamento moral para as políticas de redistri- 
A defesa do mercado significa, por outro lado, a defesa da concepção liberal do estado, entendendo este como instância separada da economia e da sociedade civil e considerando a não-intervenção do estado na economia como um corolário da natureza do estado enquanto pura instância política.

Ora esta é uma concepção que - desvalorizando a lição dos fisiocratas, de Locke e de Adam Smith - deliberadamente ignora a 'compreensão' da natureza de classe do estado (para o dizermos em linguagem marxista), revelando-se incapaz de compreender que a não-intervenção do estado na economia é apenas - como os diversos tipos de 'intervenção' - uma das formas de o estado capitalista cumprir a sua missão essencial de garantir as condições gerais indispensáveis ao funcionamento do modo de produção capitalista e à manutenção das estruturas sociais que o viabilizam.

Vistas assim as coisas, a defesa do mercado veicula uma concepção acerca da ordem social que se considera desejável e consagra uma atitude de defesa da ordem social que tudo confia ao mercado. Tal como a crítica do mercado e do seu pretenso caráter natural (por parte de keynesianos, radicais ou marxistas) significa o reconhecimento da necessidade de introduzir mudanças na ordem social estabelecida (para salvar o capitalismo) ou mesmo o propósito de substituir a ordem económico-social capitalista (que tem no mercado um dos pilares essenciais) por outra ordem social, em rotura com o capitalismo.

buição do rendimento e da riqueza. Alguns vão ao ponto de defender a ilegitimidade dos impostos, porque atingem os direitos individuais, propondo mesmo a privatização de todas as funções do estado, incluindo a polícia, os tribunais e as funções de defesa. Como é sabido, Hayek defendeu a desnacionalização da moeda: garantida a liberdade de emissão, o mercado encarregar-se-ia de escolher a(s) melhor(es) moeda(s) que se apresentassem a concorrer umas com as outras. Cfr. A. GAMBLE, ob. cit., 60/61. 
6. Em outro plano, não posso estar mais de acordo com Frédéric Lordon quando ele afirma que a construção europeia é uma "gigantesca operação de subtração política (...), de subtração de soberania popular", que "é tão somente o outro nome da própria democracia". Daí a crítica à "esquerda de direita", que fica sempre irritada quando ouve falar de soberania, por não entender que "a rejeição da soberania é mesmo a negação da democracia na Europa". ${ }^{36}$ Esta negação das soberanias nacionais, como se se tratasse de um farrapo velho, é uma atitude tão fora do mundo como a patética proclamação de Dominique Strauss-Kahn (ex-ministro todo-poderoso de Mitterrand e candidato falhado do PS às eleições presidenciais francesas): "Fizemos a Europa, agora é preciso fazer os europeus". ${ }^{37}$

É importante sublinhar, porém, que esta questão da importância das soberanias nacionais no quadro europeu foi diagnosticada na França, logo depois do referendo (29.5.2005) que 'chumbou' a 'constituição europeia'. No dia 1.6.2005, Hubert Védrine, ex-ministro socialista dos negócios estrangeiros e partidário do SIM, escreveu em Le Monde: "o que envenenou tudo foi a obstinação no sentido de se ridicularizar qualquer sentimento patriótico normal, de caricaturar quaisquer preocupações com o alargamento da União, mesmo legítimas e não xenófobas, de tornar suspeito qualquer desejo, perfeitamente normal, de as pessoas pretenderem conservar, no quadro da globalização, uma certa soberania sobre os seus destinos e a sua identidade, de varrer com desprezo qualquer crítica. Foi tudo isso, juntamente com a insegurança social, com a insegurança identitária, com o sentimento de desapossamento democrático", foi tudo isso que justificou o NÃO dos franceses. ${ }^{38}$

\footnotetext{
${ }^{36}$ Cfr. F. Lordon, "Sair do euro..., cit., 12.

37 Apud J.-P. Chevènement, ob. cit., 54 e 183.

38 Le Monde, 1.6.2005.
} 
Pouco depois, escrevia Pierre Nora (também partidário do SIM): "Estamos a pagar pela ridicularização sistemática de qualquer manifestação de apego à nação. De forma consciente ou não, passou-se o tempo a ridicularizar e a negligenciar um inconsciente coletivo muito forte, sacrificando-o às miragens de uma construção europeia, a uma Europa com falta de definição e de limites, mas que nem por isso deixava de ser posta no altar de um 'horizonte inultrapassável' e até de um 'sonho"." 39

Os fanáticos construtores de uma europa-fantasma-sem-cidadãos têm de compreender que os povos, as nações e os estados não se abatem por decreto ou por decisões de puro voluntarismo político, com recurso ao velho método do 'rolo compressor'. E os povos sabem que os estados nacionais soberanos constituem a matriz da liberdade e da cidadania e são a única entidade política que, nas condições atuais, pode opor-se às forças do capital.

Mas os reis construtores desta Tebas-Europa julgam que podem 'construir' a 'Europa' não apenas contra os cidadãos europeus, mas também sem cidadãos (fazem-se depois, talvez made in China, que ficam mais baratos...). O Tratado de Maastricht, ao criar a União Europeia, veio redistribuir os poderes no seio da UE em claro prejuízo dos países mais pequenos e mais fracos. O Tratado de Lisboa acentuou escandalosamente o desequilíbrio de poderes entre os estados-membros da UE, apesar de continuar a proclamar, hipocritamente, a igualdade entre eles. O Tratado Orçamental (2012) vem reduzir os países mais débeis a um estatuto de tipo colonial, 'governados' por executivos eurocratas, deixando claro que todo o poder que conta está entregue à Alemanha.

Parece incontestável que a Europa é constituída por povos diferentes, todos ciosos da sua independência (que celebram, frequentemente, como feriado nacional mais impor-

39 Le Monde, 4.6.2005. 
tante, o dia de uma qualquer vitória sobre o país vizinho...), que respeitam e levam a sério a soberania nacional e que já se aperceberam de que essa história da soberania partilhada é uma patranha para enganar tolos. À luz desta realidade, tenho para mim que, sem estados nacionais soberanos e iguais, a 'Europa' nunca passará de um exótico cemitério de mortos-vivos (ou de vivos-mortos). Por isso entendo que é preciso 'inventar' urgentemente uma outra Europa, porque esta Europa neoliberal enredou-se numa teia que lhe tolhe os movimentos e a própria respiração, fazendo dela uma entidade petrificada, incapaz de evoluir e de caminhar ao encontro dos seus povos.

7. Já disse atrás que o Tratado de Maastricht marca um ponto de viragem no processo de integração europeia, acentuando a nota federalista. Analisarei aqui tão só os aspetos relacionados com a criação da União Económica e Monetária (UEM): a entrada em funções do Banco Central Europeu (BCE); a entrada em circulação do euro como moeda única de vários países da UE; a aprovação e entrada em vigor do Pacto de Estabilidade e Crescimento (PEC).

Partilho a opinião daqueles que entendem terem sido essencialmente razões de natureza política as que justificaram o 'salto' que levou à institucionalização da UEM. A França não esqueceu que Paris foi bombardeada três vezes pelas tropas alemãs entre 1870 e 1940 (desta vez o país foi ocupado). Por isso, tentou, até ao fim, evitar a 'reunificação' da Alemanha. Mas Helmut Kohl ganhou o braço de ferro, 'ajudado' por Gorbatchev com a cumplicidade dos EUA. Regressada a Grande Alemanha (com a integração da RDA na RFA), renasceram os 'medos' da França, que tratou de amarrar mais a Alemanha ao barco comum europeu, aprofundando a sua inserção no tecido da Europa comunitária. A UEM surgiu, aos olhos da França, como o instrumento (político) que visava 
'controlar' melhor a 'ameaça alemã', tentando evitar o regresso aos tempos do Deutschland Über Alles.

Talvez esta solução - que esqueceu os argumentos de ordem técnica que desaconselhavam a criação da união monetária europeia - tenha ajudado a resolver problemas de relação (e de desconfiança) política entre a França e a Alemanha. Mas ela veio reforçar o papel da Alemanha como potência hegemónica, que conseguiu impor aos países da zona euro as suas concepções em matéria de política monetária e financeira (os critérios nominais do PEC, o estatuto do deutsche euro e o estatuto de independência e as competências do BCE) e conseguiu que elas ficassem consagradas nos Tratados estruturantes da UE como normas ou regras de aplicação mecânica, 'matando' a cidadania, a política e a democracia, que implicam a liberdade para tomar decisões e a responsabilidade de prestar contas por elas.

Muitos reconhecem hoje que terá sido precipitada a decisão de criar a união monetária europeia sem que estivessem reunidos os requisitos mínimos de uma zona monetária ótima: países ou regiões com níveis idênticos de desenvolvimento e de produtividade; forte integração no interior da zona monetária, quer no que se refere às transações de bens e serviços quer no que toca à mobilidade da mão-de-obra; uma estrutura política que permita um certo grau de federalização da fiscalidade e um orçamento com capacidade redistributiva (as despesas federais representam, nos EUA, 60\% da despesa pública global). ${ }^{40}$

40 Em Portugal, o erro político foi denunciado, desde o início, pelo PCP e também por autores como Sérgio Ribeiro (ob. cit.) e eu próprio (ver, por exemplo, "Nota..., cit., "A institucionalização..., cit. e A Constituição Europeia..., cit.).

Também João Ferreira do Amaral foi sempre contrário à moeda única, embora aceitando as vantagens de uma moeda comum (uma espécie de unidade de conta), a par das moedas nacionais dos países da UE. Em livro 
Compreende-se que uma zona monetária - sobretudo se pretender, como é o caso da UEM, que a sua moeda se imponha mundialmente como moeda de referência - não pode suportar no seu seio défices públicos diferenciados e significativos. Por isso é que os países que a integram devem apresentar um nível muito aproximado de desenvolvimento económico e social, para que todos possam cumprir as mesmas regras de gestão financeira. Mas este requisito falta na UEM, desde o início. Todos sabiam, por isso, que a união monetária europeia era um projeto de difícil sustentação, nomeadamente por integrar países com economias muito heterogéneas no que toca ao seu grau de desenvolvimento, aos níveis de remuneração e de vida, aos hábitos de consumo e à mobilidade, dentro do espaço europeu, dos seus trabalhadores e dos seus povos. Assim sendo, o bom senso recomendava que se desse prioridade a políticas que ajudassem a ultrapassar as disfunções originárias se tal projeto, trabalhando em conjunto, solidariamente e em cooperação, para atingir, no âmbito da

recente, o autor, para além de mostrar que a UEM nunca satisfez os requisitos de uma zona monetária ótima (os definidos por Robert Mundell no famoso artigo na American Economic Review, 1961), acrescenta ainda uma outra razão. Considerando que a CEE/UE é "uma organização meramente artificial, quase sem identidade", constituída por "países que têm a sua identidade própria, organizados em estados com muitos séculos de História", defende que, "numa situação destas, os interesses das entidades-estados não podem ser preteridos face aos interesses do todo, porque os cidadãos nacionais não aceitam a subalternidade do seu estado em relação aos interesses dos restantes". Daí a sua conclusão: "nunca o espaço europeu poderá constituir uma zona monetária ótima”. Cfr. J. F. AmArAL, Porque devemos sair do euro, cit., 71. Os adeptos do estado federal europeu não deviam esquecer estas reflexões.

Se o apoio de um Prémio Nobel ajuda, posso invocar Paul KRUGMAn ("Quando..., cit.), que considera a UEM uma fantasia e acusa as autoridades europeias de incapacidade para lidar com os problemas decorrentes da crise atual, incapacidade que traduz "falta de coragem para enfrentar o fracasso de uma fantasia”. 
UE e, em particular, no âmbito da zona euro, níveis uniformes de desenvolvimento económico e social.

Ora, é notório que as políticas adotadas até ao presente têm sido sempre em sentido contrário àquelas que este diagnóstico aconselhava. Dadas as condições históricas e os termos em que foi criada (nomeadamente o seu compromisso com os cânones mais fundamentalistas do neoliberalismo), a UEM veio destruir os sistemas de defesa dos países mais débeis da Eurozona em situações de crise (nomeadamente, a possibilidade de se financiarem através da emissão de moeda, de recorrerem à desvalorização da moeda para ocorrer a dificuldades conjunturais das suas balanças de pagamentos, de manejarem soberanamente as taxas de juro, de adotarem políticas inflacionistas, de regularem os movimentos de capitais).

Como é sabido, a consolidação do mercado interno, a construção da UEM e a densificação da União Europeia têm-se traduzido, para os estados-membros, na perda de soberania (em europês, fala-se de soberania partilhada) em vários domínios (política monetária e cambial, política financeira, agricultura e pescas, política de concorrência, etc.). E esta perda tem sido agravada pela alienação do setor empresarial do estado, que priva os estados nacionais de receitas não provenientes de impostos e de qualquer possibilidade de atuação direta enquanto empresários com presença relevante em setores estratégicos, com fortes efeitos de irradiação em outras áreas da economia.

Importa ter presente, porém, que, apesar das perdas de soberania atrás referidas, a UE não é um estado federal (embora goze, agora, de personalidade jurídica): o Parlamento Europeu não é a sede do poder político da União, e mesmo depois do Tratado de Lisboa, continua a ser um nada político; a Comissão Europeia não é um governo federal; um orçamento que mobiliza cerca de 1\% do PIB comunitário está longe de um orçamento federal digno desse nome. 
Isto significa que as competências perdidas pelos estados-membros não são transferidas para as instituições da União: nenhuma das instituições comunitárias tem a competência para (ou a responsabilidade de) definir políticas anti-cíclicas, nem existem no orçamento da UE os recursos necessários para as financiar. E como as instituições da União não são órgãos de soberania não dispõem da chamada competência das competências, i.é, não podem atribuir a si próprias novas competências.

Durante a preparação da UEM, chegou a ser proposto um esquema baseado na transferência de verbas do orçamento comunitário para ajudar (sobretudo) os pequenos países afetados por choques externos (v.g. uma baixa significativa das exportações) a desencadear políticas destinadas a ultrapassar a crise. Esta solução não foi adotada, tendo-se sacrificado a economia real e a solidariedade comunitária aos equilíbrios financeiros.

Nestes termos, amputada a sua soberania monetária e cambial e fortemente limitada a sua autonomia em matéria de política orçamental, os pequenos países do euro ficaram confinados à intervenção em matéria de salários e de emprego para enfrentar os choques externos (a chamada desvalorização interna, para substituir a desvalorização da moeda). É a política exigida para salvaguardar as taxas de lucro (combustível do processo de acumulação do capital) e para garantir ao capital financeiro a apropriação dos ganhos de produtividade.

É a política dos estados-membros da UE (imposta ou estimulada pelas instâncias comunitárias e pelas troikas), centrada, justamente, na redução dos custos unitários da força de trabalho, no aumento do horário de trabalho, na redução dos salários reais, na diminuição dos descontos patronais para a segurança social e na redução dos direitos sociais dos trabalhadores, i.é, no reforço da exploração dos trabalhadores. O estado capitalista, apesar das máscaras a que recorre para es- 
conder a sua natureza, não consegue, hoje, disfarçar a sua natureza de estado de classe, de ditadura do grande capital financeiro.

A presente crise veio confirmar o que já se sabia: em caso de crise grave, a UE não tem meios para se defender, não tem órgãos com competência política e com meios financeiros para definir políticas comunitárias que possam ser mobilizadas para ajudar os países mais fracos a ultrapassá-la. Por outro lado, falta a esta 'Europa' a cultura da solidariedade, sem a qual não se pode falar de um espaço político integrado.

E a chamada (inventada) crise das dívidas soberanas veio acelerar as consequências decorrentes da filosofia inspiradora da UEM. ${ }^{41}$ No quadro da crise, as medidas adotadas para a enfrentar têm obedecido à matriz ideológica neoliberal da UE e da UEM, indo todas no sentido de acrescentar mais crise à crise, mais recessão à recessão, mais desemprego ao desemprego, mais défice ao défice, mais dívida à dívida. Para quem entende que soluções deste tipo não resolvem problema nenhum e afundarão a Europa num círculo vicioso (recessão, mais desemprego, mais défice, mais dívida, mais recessão, mais desemprego, mais pobreza, mais desigualdade), num regresso ao 'inferno perdido' dos tempos da revolução

${ }^{41}$ Mark Blyth, ob. cit., 21-28 e 37, mostra que a chamada crise da dívida soberana "é uma crise transmutada e bem camuflada da banca", é "uma crise bancária habilmente e sobretudo politicamente transformada numa crise do setor público". Ela é, em boa verdade, uma invenção para mascarar a crise bancária que obrigou os estados a endividar-se para salvar os bancos e que pode suscitar, sobretudo na Europa, um problema sem solução ao nível de cada estado nacional (e sem solução também ao nível da UE, tal como ela existe depois de Maastricht). Basta recordar que só os três maiores bancos franceses têm ativos de valor sensivelmente igual a 2,5 vezes o PIB da França (nos EUA, o valor total dos ativos de todo o sistema financeiro corresponde a cerca de 120\% do PIB americano). Estes bancos não podem ser resgatados por um qualquer país e dificilmente podem ser resgatados pela União Europeia. 
industrial, só resta concluir que a Europa precisa de curar-se da dependência das 'drogas' do receituário neoliberal e de libertar-se da tirania do deutsche euro, o que exige uma reforma substancial das traves-mestras da Europa neoliberal, a começar pelas que decorrem do Tratado de Maastricht.

A permanência e a evolução da crise vieram revelar a verdadeira face da Europa neoliberal (a Europa do capital): um grande mercado interno, com uma economia incapaz de crescer, um espaço sem um mínimo de solidariedade e de coesão social, sem o mínimo sentimento de pertença, um espaço em que alguns estados se assumiram como 'donos da bola' e têm imposto as 'regras do jogo', humilhando os trabalhadores europeus e tratando com laivos de superioridade rácica os 'povos do sul' e os seus estados soberanos.

$\mathrm{Na}$ cimeira de 7/8 de maio/2010 a Alemanha persistiu em considerar a situação da Grécia como um caso isolado, explicável pela irresponsabilidade, pela preguiça e por outros vícios do povo grego, que se habituou a viver bem sem trabalhar. Perante as notícias, Jürgen Habermas comentou: "A prioridade das preocupações nacionais [alemãs] nunca se manifestou com tanta clareza como na resistência robusta de uma Chanceler que bloqueou durante semanas a ajuda europeia à Grécia e o mecanismo de emergência para salvar o euro". E 'acusou' Merkel de não ser capaz de ultrapassar "a consideração oportunista dos joguinhos da política interna", cedendo ao "medo das armas de destruição maciça da imprensa tablóide" (esquecendo "a força destrutiva das armas de destruição maciça dos mercados financeiros") e "bloqueando uma ação conjunta da União que teria apoiado atempadamente a Grécia contra a especulação que visava a bancarrota do estado". Com razão, Habermas confessa: "apercebi-me, pela primeira vez, da possibilidade real de um fracasso do projeto europeu". ${ }^{42}$

${ }^{42}$ Cfr. J. Habermas, ob. cit., 135-140 e 153/154. 
Mas esta crise, a sua permanência e a sua evolução, abriu também, como é notório, uma crise da 'Europa', da "Europa como ela é" (Jacques Chirac), uma crise deste 'monumento' ao neoliberalismo fundamentalista em que os cidadãos e os povos da Europa não se revêem.

8. Embora a UE não seja um estado federal, o BCE foi concebido como uma instância supranacional, um verdadeiro banco central federal. Os bancos centrais nacionais dos países do euro (meras repartições periféricas do $\mathrm{BCE}$ ) têm um protagonismo inferior ao dos bancos centrais dos estados federados da União americana, sendo obrigados a cumprir as deliberações e orientações do BCE.

Os estados da zona euro perderam a capacidade de se financiar através da emissão de moeda. Ao menos para os estados mais fracos, é, verdadeiramente, a privatização do estado, colocando os estados nacionais na mesma situação de qualquer particular: quando precisam de dinheiro, vão aos "mercados" e estes é que decidem se concedem crédito ou não (e em que condições), decidindo, em último termo, o que convém ou não convém ao país, apesar de não terem nenhum mandato democrático para o exercício dessa função de gestores da res publica.

O BCE reivindica para si próprio "um núcleo central de soberania." 43 Seja ou não 'soberano' o BCE, a verdade é que o facto de não existir um estado europeu com o qual o BCE seja obrigado a concertar a sua atuação reforça consideravelmente a 'independência' deste banco central, que é o banco central mais fiel aos cânones monetaristas radicais, o banco central mais 'independente' que se conhece, desde a 'revelação' do dogma neoliberal da independência dos bancos centrais.

43 É o que se afirma no Boletim Mensal do BCE (outubro/2000, 55): "o Eurosistema foi dotado de um núcleo central de soberania". 
A sua independência traduz-se no facto de ele estar impedido de solicitar ou de receber instruções das instituições comunitárias ou dos governos dos estados-membros. Segundo o entendimento a que se chegou no Conselho de Helsínquia (dezembro/1999), as relações do BCE com outras instâncias (comunitárias ou nacionais) competentes no domínio das atribuições do Banco mantêm-se ao nível de um diálogo não vinculativo, do qual não pode decorrer qualquer compromisso do BCE no sentido de vir a coordenar as suas decisões de política monetária com as decisões de qualquer outra instituição sobre as demais áreas da política económica e social.

O objetivo primordial do BCE, responsável pela política monetária única dos países que adotaram o euro como moeda, é, segundo os seus Estatutos, o da estabilidade dos preços, a ele devendo ser sacrificados todos os outros objetivos de política económica, nomeadamente o crescimento económico, a luta contra o desemprego e a promoção do pleno emprego, a redistribuição do rendimento, o desenvolvimento regional equilibrado. É, pois, um banco central que não foi dotado dos meios que lhe permitam atuar no combate às crises cíclicas.

Muito diferente é a situação nos EUA (como no Japão, no RU, na China e em outros países), onde o banco central é uma agência governamental entre outras, independent within the Government, obrigado a trabalhar no sentido de adequar a sua ação não só ao objetivo da estabilidade dos preços como aos objetivos do crescimento económico e da promoção do emprego, cuja definição e concretização cabe aos órgãos do poder político.

Acresce que os países referidos no parágrafo anterior (e muitos outros) podem financiar as políticas públicas recorrendo à via monetária (i.é, à emissão de moeda). Ao invés, a UE e os estados-membros estão impedidos de beneficiar de qualquer tipo de crédito concedido pelo BCE, ao qual é 
igualmente vedado comprar diretamente (no mercado primário) títulos de dívida emitidos pela União ou pelos estados membros, bem como garantir, por qualquer meio, obrigações ou dívidas da União ou dos estados-membros.

Naqueles países, quando, movidos por estratégias especulativas, por pânico ou por outras razões, os 'investidores' decidem vender em larga escala títulos de dívida pública de que são titulares, o respetivo banco central, no cumprimento das suas funções, intervém no mercado a comprar esses títulos, para evitar o aumento das taxas de juro. Ao invés, segundo os seus Estatutos, o BCE não tem nada que ver com estes problemas e, em bom rigor, só poderia comprar títulos de dívida pública no mercado secundário se tal intervenção fosse justificada pela necessidade de salvaguardar a estabilidade dos preços. Os estados-membros da zona euro (nomeadamente os mais débeis) ficam sozinhos a enfrentar os ataques dos especuladores (a "sida da economia mundial", como lhes chamou Jacques Chirac em 1995), dos "mercados", dos grandes bancos internacionais e das instituições financeiras por eles geridas (fundos de investimento, fundos de pensões, etc.).

A esta luz, percebemos o que à primeira vista parece injustificável. Em julho/2008, já com a crise na rua, o BCE fez de contas que não via nada ou que nada tinha que ver com a crise, porque o seu 'negócio' é outro. Receoso de um imaginário perigo inflacionista, decidiu aumentar a taxa de juro de referência para $4,25 \%$.

A dimensão da crise forçou o BCE a comprar, no mercado secundário, 16,5 mil milhões de euros de títulos de dívida soberana e de dívida privada (20.5.2010). Só que este acrisolado 'patriotismo europeu' foi estimulado não por influência da UE ou de estados-membros da União, mas por sugestão de cerca de meia centena de instituições bancárias que, no início desse mês de maio, tinham escrito ao Conse- 
lho de Governadores do BCE (com conhecimento de alguns governos de estados-membros da UE), pedindo que o Banco comprasse títulos de dívida dos estados em dificuldade, porque o mercado interbancário não estava a desempenhar este papel (os bancos desconfiavam e continuam a desconfiar uns dos outros). Como os bancos constituem uma família muito unida (como se viu na 'história' da supervisão do Banco de Portugal relativamente ao BPN), o independente BCE acedeu a fazer um 'jeitinho', intervindo no mercado secundário, ainda que 'contornando' os seus intocáveis estatutos. O que as instâncias políticas nacionais e as instituições da União não conseguem (porque os estatutos do BCE não o permitem!) é conseguido por intervenção dos bancos privados. São "os mercados" que mandam nesta 'Europa', não os cidadãos, os estados nacionais ou as instâncias comunitárias.

Começou assim o processo de transferência de alguns ativos que poderiam cheirar a lixo tóxico da banca privada para a esfera pública. E este tem sido o papel do BCE, verdadeiro 'pai' protetor da banca privada, para a qual tem transferido milhões e milhões de euros a taxas de juro próximas de zero, verdadeiras doações que oferecem aos bancos a liquidez necessária para continuarem a praticar o seu 'jogo' preferido, a especulação, agora com a dívida soberana dos 'países do sul', aos quais emprestam dinheiro a taxas de juro que já ultrapassaram os $20 \%$.

A crise continuou a arrastar-se, com graves prejuízos para os povos da Europa. Mas a verdade é que o BCE só veio a público dizer que tudo faria para salvar o euro quando o incêndio que deixou lavrar durante demasiado tempo chegou às barbas da Itália e da França (setembro/2012). Metendo os Estatutos na gaveta, o BCE assumiu então a posição de prestamista de última instância no âmbito do Eurosistema, anunciando a sua disponibilidade para comprar títulos de dívida pública no mercado secundário, sem limites, se tal for 
necessário pôr cobro a movimentos especulativos contra o euro. Avisou, no entanto, que só podem beneficiar desta sua atuação os países com acesso direto ao mercado financeiro (o que não é, de momento, o caso de Portugal) e deixou claro que este 'beneficio' só será concedido após a aceitação de determinadas condições (= programas de austeridade) definidos pelo próprio BCE.

A verdade é que esta atitude foi o bastante para que "os mercados" moderassem as suas exigências em matéria de taxas de juro. E foi este clima que permitiu ao governo português encenar o 'número' do regresso aos mercados (janeiro/2013), embora a taxa de juro exigida pelos "mercados", para um empréstimos a 5 anos, tenha ficado em 4,89\%, uma taxa superior à que pagamos à troika (agora, segundo o governo, cerca de 3,8\%), superior à que pagávamos pelos empréstimos que então se amortizaram, uma taxa que é incomportável para uma economia que não cresce, praticamente, desde a entrada do euro em circulação e que, por este caminho, não se sabe quando retomará o crescimento sustentado e a que taxas.

Amparado nos Estatutos (que constam dos Tratados!), o BCE tem usado a sua 'soberania' para atuar como instrumento da financeirização da Europa e guardião dos interesses do capital financeiro especulador. Quando os bancos ficaram sem fundos (gastos, criminosamente, em operações especulativas nos 'jogos de casino’ em que se especializaram), o BCE não apoiou financeiramente as operações de salvamento levadas a cabo pelos estados nacionais, que foram obrigados a endividar-se junto dos "mercados" (os mesmos bancos especuladores cujas 'dívidas de jogo' foram pagas com o dinheiro dos contribuintes) e que não hesitaram em 'confiscar' os direitos e os rendimentos dos seus cidadãos (imolados no altar das políticas de austeridade, impostas pelo BCE, vestindo a própria farda ou inserido no exército da troika). 
Mas o mesmo BCE vem financiando, com dinheiros públicos, a atividade especulativa dos bancos privados, que continuam a fazer a única que sabem fazer: especular, agora com a dívida pública dos estados que se endividaram para os salvar da falência. Tem razão Mark Blyth quando defende que "a austeridade não é apenas o preço da salvação dos bancos. É o preço que os bancos querem que alguém pague". ${ }^{44}$ A pretexto da crise que provocaram através de práticas criminosas pelas quais ninguém foi responsabilizado, os bancos têm recebido do erário público muitos milhares de milhões de euros (e dólares), que vêm utilizando para financiar o crime sistémico.

Há quem defenda que "a Europa poderá ter que deixar cair o euro para se salvar a si própria". ${ }^{45}$ Mesmo que assim não seja, eu creio que quem quiser salvar o euro (e a 'Europa' que o criou) tem de entender que é imperioso rever, de alto a baixo, este estatuto esquizofrénico do BCE. O BCE tem de abandonar o esplêndido isolamento da sua independência anti-democrática e deve assumir-se como um verdadeiro banco central, com capacidade para emitir moeda destinada a financiar diretamente os investimentos da União e dos estados-membros, para adequar a taxa de câmbio do euro às necessidades conjunturais, para adquirir títulos de dívida pública no mercado primário e para ajudar os países da UE a promover uma estratégia de desenvolvimento sustentado e a prosseguir políticas públicas de combate às crises.

Não é tolerável este domínio do capital financeiro sobre a política e sobre a economia. Mesmo aqueles que, na senda de Keynes, apenas pretendem salvar o capitalismo, em moldes que permitam a sua coexistência com as regras do jogo democrático, têm de levar a sério as propostas keynesianas no

${ }^{44}$ Cfr. Austeridade..., cit., 24.

45 É o caso de Joseph Stiglitz, Expresso, 9.3.2013. 
sentido da defesa da necessidade de uma certa coordenação pelo estado da poupança da comunidade e dos fluxos do investimento por ela alimentados. Por estas razões defendeu Keynes a necessidade de "uma ampla expansão das funções tradicionais do estado", a necessidade de "uma ação inteligentemente coordenada" para assegurar a utilização mais correta da poupança nacional, a necessidade da "existência de órgãos centrais de direção", a necessidade de "medidas indispensáveis de socialização" e de uma certa socialização do investimento ("a somewhat comprehensive socialization of investment").

Perante o beco sem saída cada vez mais evidente a que conduzem as estruturas neoliberais da própria UE e as políticas neoliberais em curso, sinto-me confortado por ver que um número crescente de autores se vem pronunciando no sentido de que a saída da crise generalizada do capitalismo exige medidas de fundo, que passam pelo abandono do princípio da liberdade de circulação do capital, pela destruição dos paraísos fiscais, pela socialização do setor bancário e segurador, pelo fim da independência absoluta dos bancos centrais, pela revogação do princípio da banca universal (regulação estrita da atividade financeira), pelo reforço da progressividade do sistema fiscal, pela tributação das transações financeiras, pelo combate à fraude e à evasão fiscais, pela "eutanásia dos rendistas" (como pretendia Keynes), pelo reforço do estado social, pela melhoria dos rendimentos do trabalho, pela defesa dos direitos dos trabalhadores.

Para tanto, é necessário que as instâncias políticas democraticamente legitimadas não sejam substituídas pelos "mercados"; é necessário impedir que o mercado substitua a política; é necessário libertar a política dos dogmas neoliberais, que tudo subordinam ao mercado. Tal como os estados nacionais, a União Europeia não pode ser dominada pelos bancos. Tem que ser ela a dominar os bancos, a começar pelo BCE. "Os estados não podem permitir-se perder o combate 
que os opõe aos mercados financeiros: a sobrevivência de um sistema mais ou menos civilizado depende disso". ${ }^{46}$

9. O euro foi uma das 'maravilhas' que veio no pacote da UEM. Hoje sabemos que ele arrastou consigo alguns 'danos colaterais', em especial o BCE (com a sua independência e as suas competências de inspiração monetarista) e o PEC (“estúpido" e "medieval”, na catalogação do então Presidente da Comissão Europeia Romano Prodi, ou "Pacto de Estabilidade e Estagnação”, na designação de J. Ferreira do Amaral). Tudo isto e, mais recentemente, o chamado Pacto Orçamental, com a sua regra de ouro (e outras 'regras' igualmente perigosas, embora de metais menos nobres) só pode entender-se no quadro de uma estratégia destinada a consolidar o controlo do capital financeiro (os chamados "mercados") sobre a economia real e sobre as políticas económicas da UE e dos seus estados-membros (política monetária, política cambial, política orçamental).

Impostas pela Alemanha a sua estrutura e as suas regras, só a Alemanha tem ganho com este deutsche-euro. Uma vitória que pode vir a tornar-se uma vitória de Pirro. Porque a verdade é que, com a chegada do euro, a economia europeia entrou num período de crescimento rastejante, com quebra do PIB em alguns países, durante uma parte dos anos posteriores a 2000. Entre 2008 e 2011, doze países da UE (entre os quais o RU, a Itália e a Espanha) registaram um crescimento negativo. Mesmo a economia alemã não foi além de um crescimento do PIB de 0,7\% em 2012, sendo quase certo que a França não escapará à recessão (a França não cumpriu as metas acordadas para o défice das contas públicas em 2012 e já anunciou que não irá cumpri-las também em 2013). No final de 2012 a eurozona, no seu conjunto, estava em reces-

${ }^{46}$ Cfr. James Galbraith, ob. cit. 
são técnica, com uma taxa de crescimento negativa $(-0,1 \%)$ nos últimos três trimestres.

As novas 'regras do jogo' que vieram com o euro favoreceram as posições e reforçaram as vantagens dos países mais fortes da Eurozona (em especial a Alemanha), impedindo ao mesmo tempo o crescimento económico e o desenvolvimento social dos países mais débeis, entre os quais Portugal.

Manda a verdade que se diga não serem surpresa, para alguns, as consequências negativas da adesão ao euro por parte de países como Portugal.

Logo em 1997, durante o período de discussão do projeto de criação da UEM (BCE e euro-moeda-única), Sérgio Ribeiro fazia o seguinte diagnóstico: "Num contexto mundial diferente em que o modo de produção capitalista ocupa o espaço planetário, o capital financeiro prevalece sobre o capital aplicado produtivamente e, ao mesmo tempo, a predominância do multinacionalismo privado passa à transnacionalidade, através da substituição de estratégias plurinacionais adaptadas aos países de implantação por uma estratégia transnacional, desprezando soberanias nacionais e impondo políticas. A moeda única 'europeia' é peça decisiva dessa estratégia transnacional privada. Mas só o poderá ver claramente quem tiver uma perspetiva de classe. Porque há classes...". E, referindo-se às eventuais vantagens atribuídas ao euro-moeda-única, concluía, premonitoriamente: "o que se afirma, hoje, que será 'resolvido' pelo euro e adjacentes, amanhã se comprovará que foi agravado. Será o momento oportuno para uma nova ilusão e para procurar calar quem quiser lembrar o que, hoje, foi de(a)nunciado". ${ }^{47}$

Nesse mesmo ano de 1997, Carlos Carvalhas, então Secretário-Geral do PCP, fez esta previsão, ao intervir na Assembleia da República no quadro de uma interpelação deste

${ }^{47}$ Cfr. ob. cit., Ficha B3 e Ficha D9. 
partido sobre a moeda única, durante a qual anunciou a sua posição contrária à adesão de Portugal ao euro: “A moeda única é um projeto ao serviço de um diretório de grandes potências e de consolidação do poder das grandes transnacionais (...), por uma nova divisão internacional do trabalho e pela partilha dos mercados mundiais. A moeda única é um projeto político que conduzirá a choques e a pressões a favor da construção de uma Europa federal, ao congelamento dos salários, à liquidação dos direitos, ao desmantelamento da segurança social e à desresponsabilização crescente das funções sociais do estado".

Em maio de 1998, os deputados do PCP ao Parlamento Europeu justificaram o voto contra aquele projeto alegando que ele serviria para "impor estratégias que concentram riqueza, agravam desemprego, agudizam assimetrias e desigualdades, criam maior e nova pobreza e exclusão social, diminuem a soberania nacional e aumentam défices democráticos", arrastando consigo, ao mesmo tempo, uma "evidente polarização do poder na instituição [o BCE] que condicionará todas as políticas dos estados-membros". ${ }^{48}$

${ }^{48}$ Muito diferente foi a declaração dos deputados do PS ao Parlamento Europeu, justificando o seu voto favorável à criação da UEM e à adesão de Portugal à eurozona. O voto refere o "orgulho" de participar "neste momento, verdadeiramente crucial da história da Europa, que assim dá sinais de não querer envelhecer e declinar". A desgraça é que a Europa do euro envelheceu muito desde então e continua a declinar, envenenada pelas drogas neoliberais de que não consegue libertar-se e que estão a conduzi-la à ruína.

Quanto a Portugal, os deputados do PS anunciavam um futuro risonho (um futuro rosa): "Portugal desmentiu (...) todas as teorias académicas e ideias adquiridas: o crescimento económico do país acelerou, o nível de vida dos portugueses melhorou e a capacidade de exportar aumentou". Tudo previsões que a realidade não confirma. E os portugueses estão hoje a pagar a conta, acusados de viver acima das suas posses... 
10. No contexto europeu, a Alemanha foi, sem dúvida, o país que mais beneficiou com o euro (praticamente, o único), aproveitando ainda da baixa do preço do petróleo em euros, graças à desvalorização do dólar face ao euro. Estas vantagens ajudarão a compreender que a balança dos pagamentos correntes da Alemanha (negativa em 1991, ano da reunificação) começasse a registar saldos positivos logo em 2002, dois anos após a entrada em circulação do euro (entre 1995 e 2007 , o saldo passou de $-1,7 \%$ para $+7,5 \%$ do PIB). Mas o 'êxito' da Alemanha tem um reverso: o crescimento acentuado do défice da balança de pagamentos correntes de vários países da zona euro, entre os quais Portugal (de um saldo de $+2,7 \%$ do PIB em 1995 passou para um saldo de -10,1\% do PIB em 2007). Faz todo o sentido falar de deutsche euro...

Mas há mais. Num espaço de livre comércio como a UE, no quadro do mercado interno único, acontece o absurdo, o contrário do que deveria ser a cooperação entre os estados integrantes de um mercado único (sobretudo quando vários desses estados têm a mesma moeda). A Alemanha, que tem a economia mais forte a operar neste mercado, desencadeou, com base na Agenda 2010, uma política destinada a provocar a baixa dos salários e o incremento da precariedade do emprego, reduzindo significativamente o poder de compra da grande maioria dos alemães, para ganhar vantagem competitiva perante os seus parceiros também no domínio dos custos da força de trabalho. ${ }^{49}$ Apesar de concebida e executada por um governo social-democrata, trata-se de uma política im-

49 O 'êxito' foi tal que, em 2008, 28\% dos trabalhadores alemães trabalhavam nestes setores de baixos salários criados pela política do governo do SPD (cfr. T. Van TreEck, ob.cit., 10). E em 2011, segundo as informações disponíveis, cerca de 5 milhões de trabalhadores alemães ganhavam até 400 euros mensais (em trabalhos precários, muitas vezes a tempo parcial, grande parte deles 'oferecidos' às mulheres, para conciliar o trabalho doméstico com o trabalho profissional...), sendo que 11,5 
perialista de cariz mercantilista, apostada em conseguir o saldo positivo das suas contas à custa dos défices dos seus parceiros

milhões de alemães viviam abaixo do limiar da pobreza (dados colhidos em El País, 4.1.2011 e em Avante,13.1.2011).

Nestas condições, compreende-se que a esperança de vida da grande maioria dos alemães (as pessoas com rendimentos inferiores a três quartos do rendimento médio) tenha diminuído de 77,5 anos em 2001 para 75,5 anos em 2010; nos estados da antiga República Democrática da Alemanha, esta baixa foi ainda mais acentuada: de 77,9 anos para 74,1 anos (dados oficiais anunciados no Parlamento alemão, segundo os jornais de 15.12.2011). Salta à vista que esta estratégia social-democrata de Schröder, de cunho marcadamente neo-mercantilista, não serviu os interesses dos trabalhadores alemães (por isso há quem lhe chame camarada dos patrões).

Em geral, os especialistas consideram a evolução da esperança média de vida um índice mais adequado do nível de vida e do bem-estar das populações do que os índices que se baseiam nas estatísticas do PIB ou do rendimento. É importante, por isso mesmo, termos uma ideia do que passa num país como os EUA, onde a ideologia neoliberal é quase uma 'religião oficial do estado'. Socorro-me de informações colhidas em J. Stiglitz, O Preço..., cit., 12/13 e 73-77. A esperança média de vida dos mais pobres (sobretudo as mulheres) tem vindo a decrescer nos últimos anos, ocupando os EUA o último lugar entre os países desenvolvidos. Sabendo que a esperança de vidas dos mais pobres é 10\% inferior à dos 1\% do topo, os EUA ocupavam, em 2009, o 40. ${ }^{\circ}$ lugar, atrás de Cuba (que estava à frente dos EUA também no que se refere à taxa de mortalidade infantil, outro índice relevante do nível de bem-estar e de justiça social). São dados que ganham sentido à luz das condições de vida miseráveis de milhões de americanos. Em 2011, dados oficiais indicam que um em cada sete americanos dependem de ajudas do estado para satisfazer as suas necessidades básicas. E mostram que o número de famílias a viver em situação de pobreza extrema (dois dólares diários ou menos por pessoa) duplicou entre 1996 e 2011, cifrando-se neste último ano em 1,5 milhões de famílias, sendo que $1 / 4$ das crianças americanas vivem em situação de pobreza. Só a violência de uma sociedade tão desigual e tão desumana como esta permite compreender que os EUA tenham a taxa de encarceramento mais elevada do mundo: um em cada cem americanos adultos estão na cadeia (2,3 milhões de pessoas, recrutadas entre os menos instruídos, os mais pobres, as minorias étnicas, os desempregados). 
comerciais e empenhada em transferir para os restantes países da zona euro os custos da reunificação e da recuperação da economia alemã.

O deutsche euro foi um instrumento poderoso ao serviço desta política, que contraria em absoluto a filosofia orientadora da integração europeia, põe em causa a coesão social no seio da sociedade alemã e no seio da UE e ameaça a estabilidade da frágil UEM, fortemente afetada pelas suas consequências. Com base nela, a Alemanha 'exportou' os seus défices externos para os países mais fracos que com ela partilham a mesma moeda. E esta 'exportação' foi a mola impulsionadora da dívida externa (dívida pública e dívida privada) de vários países da zona do euro, em especial os 'países do sul'. ${ }^{50}$

Por outro lado, essa política conduz a uma contribuição da Alemanha para a procura europeia global muito inferior ao seu peso na economia da zona euro, provocando défices comerciais cada vez maiores dos parceiros europeus da Alemanha, obrigados a endividar-se para pagar os bens que a Alemanha precisa de exportar. $\mathrm{O}$ respeito pelos Tratados estruturantes da UE e pelas 'regras do jogo' no seio de um espaço com a mesma moeda deveria levar a Alemanha a adotar medidas capazes de aumentar o rendimento disponível dos alemães, de modo a que o aumento da procura interna na Alemanha ofereça mercados aos demais países da Europa, que estão a 'financiar' os excedentes da Alemanha. Só assim os 'parceiros' da Alemanha na zona euro poderiam pagar, sem se endividarem, os bens que a Alemanha lhes vende (e preci-

${ }^{50}$ No que diz respeito a Portugal, o montante da dívida externa era ainda, em 2000, inferior a 50\% do PIB. A partir desta data, em resultado da adesão ao euro, a dívida externa portuguesa começou a subir, em termos de percentagem do PIB: em 2007 situava-se ainda abaixo de 70\% do PIB, mas em 2008 a nossa dívida externa, medida em percentagem do PIB (71,6\%), era a mais elevada da zona euro. 
sa de vender, porque uma percentagem elevada das exportações alemãs destina-se ao mercado comunitário).

A verdade, porém, é que a Alemanha faz gala de não cumprir os Tratados, nada fazendo para anular (ou reduzir) os excedentes da sua balança comercial e das contas públicas (7\% do PIB). Ao contrário: vem reforçando os seus saldos positivos à custa dos défices comerciais, dos défices orçamentais e da dívida externa (pública e privada) dos 'países do sul', aos quais prega sermões sobre a necessidade de cumprir, custe o que custar, as normas dos Tratados (as que convêm à Alemanha) e as exigências da troika. Têm razão, por isso mesmo, todos aqueles que entendem que "a mania da austeridade de Angela Merkel está a destruir a Europa". ${ }^{51}$

Apesar desta situação escandalosa, foi preciso esperar até meados de novembro/2013 para que o Presidente da Comissão Europeia viesse (finalmente!) anunciar que a Comissão iria abrir um procedimento para averiguar a situação de incumprimento dos Tratados por parte da Alemanha. Sintomaticamente, esta medida só foi anunciada (do anúncio à execução vai todo um mundo...) depois de a Administração americana ter vindo a público 'acusar' a Alemanha de estar a prejudicar a economia europeia e a economia mundial. Até então, apesar de ver a Europa a ser destruída a cada dia que passa, a Comissão Europeia esqueceu-se por completo do seu papel de garante do cumprimento dos Tratados. De todo o modo, o espetáculo do Presidente da Comissão Europeia (que as televisões transmitiram) a anunciar aquele procedimento foi verdadeiramente deprimente. Quem o ouviu e viu não pode deixar de concluir que o Presidente da Comissão Europeia subiu ao palco apenas para europeu ver (depois da intervenção pública dos EUA, seria escandaloso não fazer

51 Assim, o semanário inglês New Stateman, julho/2012 ( Apud J. A. FERNANDES, ob. cit.). 
o seu 'número'). Mas o que os europeus viram foi um 'capataz' embaraçado, receoso e comprometido, a dizer ao 'patrão' que aquilo não era para levar a sério, que a Europa precisava era de muitas 'alemanhas'. Parece óbvio que tudo se vai passar como a Alemanha quiser. Mas parece óbvio também que os povos europeus não precisam das 'alemanhas' que, de forma contumaz, não cumprem os tratados que impõem aos outros.

Em livro recente, J. Ferreira do Amaral sustenta, com bons argumentos, que "a moeda única criou um enviesamento recessivo para a Europa, aprofundou o fosso entre países mais competitivos e menos competitivos, criou um espaço economicamente instável, sem meios de corrigir desequilíbrios conjunturais, e retirou possibilidades de crescimento às regiões presentemente menos competitivas, mas que são justamente as de maior potencial de crescimento futuro". "O euro - conclui - poderá ter lançado a Europa num processo irreversível de decadência e de ressentimentos amargos". ${ }^{52}$

11. A presente crise da Europa da moeda única veio confirmar que as 'vantagens' do euro não passavam de miragem (ou de propaganda enganosa). A começar pela vantagem das vantagens: a de livrar os países da eurozona de ataques especulativos contra a moeda única. Esta vantagem era, afinal, inconsistente, como Sérgio Ribeiro antecipara em $1997 .{ }^{53}$

Repito o que digo atrás: a crise (uma crise anunciada) evidenciou uma grave deficiência da 'Europa do euro' para a qual venho chamando a atenção há anos: em caso de crise grave, a 'Europa' não tem qualquer resposta para ajudar os países mais débeis.

52 Ver J. Ferreira do Amaral, Porque devemos sair do euro, cit., 15, 72,92 e 93 ss.

53 Cfr. ob. cit., Ficha D2. 
No quadro da UEM, o euro é uma moeda sem estado. É a moeda de um espaço que não tem um parlamento nem um governo dotados de legitimidade e de competência para definir políticas e dotados de meios para as executar, um espaço que não tem uma política económica integrada nem um orçamento suficientemente forte para ter efeitos redistributivos, nem tem uma política fiscal minimamente harmonizada, nem assume uma dívida comunitária (uma 'dívida federal').

$\mathrm{Na}$ altura da adesão ao euro, vários países adotaram a moeda única com paridades que sobrevalorizaram muito as moedas nacionais substituídas pelo euro. Estes países (entre os quais Portugal) passaram a exportar em moeda forte, o que tornou mais caros os seus produtos nos mercados externos. ${ }^{54}$ Acresce que o desejo, por parte dos grandes países da Eurozona, de fazer do euro uma moeda forte, capaz de se afirmar como moeda de reserva alternativa ao dólar, conduziu a uma valorização ainda maior da moeda única. Nestes quase treze anos de existência, calcula-se que rondará os $34,5 \%$ a valorização do euro em relação ao dólar. ${ }^{55}$

Esta valorização poderá ter sido benéfica para os países mais fortes, que exportam (sem grande concorrência) bens de produção essenciais ao desenvolvimento da atividade produtiva de outros países e bens e serviços de tecnologia avançada e de elevado valor acrescentado. Mas afetou muito negativamente a capacidade de crescimento dos países mais débeis. Para países como Portugal, que exportam essencialmente produtos de baixa tecnologia e de fraco valor acrescentado, a valorização do euro significou, só por si, um

54 Por alturas da adesão ao euro (31.12.1999, a Espanha desvalorizou a peseta em 30\%; o Governo português, sempre fanfarrão, ficou-se pelos 12\% (um euro=200,482 escudos).

55 No momento do seu lançamento o euro cotou-se a 0,95 dólares, tendo atingido a cotação mais elevada em julho/2008: 1,58 dólares. Cfr. C. Lapavitsas e outros, Eurozone Crisis..., cit., 36. 
aumento de $34,5 \%$ do preço dos produtos portugueses. ${ }^{56}$ O desafio do euro a que se referiam os defensores da nossa entrada para o 'pelotão da frente' veio a traduzir-se, como hoje é claro, em resultados contrários aos que os 'bravos do pelotão' esperavam. “A adesão ao euro teve consequências contrárias àquelas que estiveram por detrás da nossa adesão à Europa. Com o euro e, mais ainda, com a crise do euro e, mais ainda, com as medidas para combater a crise do euro, aquilo que temos já é o sequestro da democracia e a condenação à pobreza durante gerações". ${ }^{57}$

Tomando o período entre 2001 e 2009, a economia portuguesa quase não cresceu (em média, 0,5/0,6\% ao ano, muito pouco, se compararmos com a taxa de $5 \%$ registada na década 1971-1980 ou com a taxa de 4\% no período entre 1986 e 2000); o investimento público diminuiu 3\% ao ano, tendo diminuído também a despesa pública agregada; o défice público quase triplicou; o endividamento do estado, das empresas e das famílias aumentou; a produção industrial diminuiu $(-1,8 \%$ ao ano); o défice da balança de pagamentos correntes aumentou (17 mil milhões de euros em 2009); a taxa de desemprego quase duplicou; o poder de compra da população diminuiu (cerca de $0,3 \%$ ao ano entre 2005 e 2009); a parte do rendimento do trabalho no rendimento nacional diminuiu acentuadamente. Pela primeira vez há muitos anos, o PIB baixou ininterruptamente em 2010, 2011 e 2012 (3,2\% neste último ano), e vai continuar a

56 E. Stockhammer (ob. cit., 17) chama a atenção para o facto de, desde a introdução do euro, se ter registado uma acentuada divergência das taxas de câmbio reais para os países da Eurozona. Relativamente a países como Portugal, Espanha, Irlanda e Grécia, o autor calcula que a Alemanha tenha beneficiado, desde 1999, de uma desvalorização, em termos reais, de $20 \%$.

57 Cfr. J. C. Rosas, ob.cit. 
diminuir em 2013, não se sabe até quando. O reino do euro não tem sido bom para Portugal. ${ }^{58}$

12. À luz do que fica dito, impõe-se fazer dois esclarecimentos.

Em primeiro lugar, o problema em equação em 2008 e que a crise veio agudizar não se apresenta, pois, para Portugal e para outros países (como a Espanha, a Grécia e a Irlanda), como um problema de dívida pública (um problema de dívida soberana) mas como um problema de dívida externa (pública e privada), que representava mais de $3 / 4$ da dívida pública.

Vários autores vêm sustentando, aliás, que o endividamento externo dos países da 'periferia' da Eurozona “é largamente devido ao comportamento do setor privado no quadro da UEM. Incapazes de concorrer com as economias do 'centro', os setores privados periféricos geraram enormes défices financeiros". ${ }^{59}$ A origem da dívida externa destes países está, pois, nos défices das respetivas balanças de pagamentos correntes. O resto é obra dos mecanismos bem oleados da especulação financeira profissional, da crise e das políticas de salvamento do sistema financeiro, que agravaram e prolongaram a crise e as suas consequências. Por isso é que a dívida externa aumentou mesmo nos países em que o défice das contas públicas diminuiu e não ultrapassou o limite de 3\% imposto pelo PEC (a Espanha e a Irlanda tinham saldos positivos). O que aconteceu em todos eles foi um aumento do défice privado muito superior ao do défice público (mesmo na Grécia e em Portugal, onde se registou um aumento deste último défice).

Em segundo lugar, a situação criada em Portugal e em outros países não pode explicar-se pelos vícios dos 'países do

${ }^{58}$ Ver P. Carvalho, “O Pacto..., cit., 161-169.

59 Cfr. C. Lapavitsas e outros, The Eurozone..., cit., 1 e 2. 
sul', cujos povos preguiçosos persistiram no 'pecado' de querer viver acima das suas posses. No início da crise, mais de $60 \%$ das famílias portuguesas não deviam nada aos bancos; a dívida das famílias era, em grande parte, dívida das famílias de rendimentos mais elevados; uma fatia importante desta dívida foi contraída para a compra de habitação própria, uma escolha racional, tendo em conta a quase inexistência do mercado de arrendamento, o nível elevado das rendas e as taxas de juro relativamente baixas. ${ }^{60}$ Acresce que o peso do crédito mal parado relativo às dívidas das famílias era bastante inferior ao do crédito mal parado resultante de dívidas das empresas.

Estudos desenvolvidos por Costas Lapavitsas e outros permitem sustentar a conclusão de que a proporção da dívida privada no conjunto da dívida externa aumentou acentuadamente, em Portugal e em outros países do euro, a partir da instauração da UEM e, em setembro/2010, a dívida externa privada (nomeadamente do sistema financeiro e das grandes empresas) representava, em Portugal, $85 \%$ da dívida externa total (87\% na Espanha e 58\% na Grécia) ${ }^{61}$

Importa saber, por outro lado, qual o destino dos empréstimos contraídos no estrangeiro pela banca e pelos grandes grupos económicos. Para investimento novo não foi, porque o investimento diminuiu, enquanto percentagem do PIB, ao longo do período que vai de 1995 a 2007. O que se passou em Portugal na sequência da adesão ao euro foi o aumento do peso das importações, que passou de 34\% do PIB em 1995 para 40\% do PIB em 2007. A adoção do euro trouxe-nos, em suma, "uma substituição da produção nacional por bens e serviços provenientes do exterior na despesa

${ }^{60}$ São dados oficiais, que podem ver-se no Inquérito à Situação Financeira das Famílias 2010 (Banco de Portugal e INE, maio/2012).

61 Cfr. C. Lapavitsas e outros, The Eurozone..., cit., 1 e 2. 
de consumo, de investimento e nas exportações portuguesas. Isto é, aprofundou-se a dependência externa da economia portuguesa", ${ }^{62}$

Com um estado fraco do ponto de vista financeiro e amputado dos meios que poderiam permitir-lhe uma intervenção estratégica na orientação do investimento, são os bancos que exercem essa função que deveria ser uma função de soberania: decidir sobre o consumo e o investimento e sobre o destino do investimento global. E, como é notório, a banca, os grandes grupos económicos e os governos de serviço (com a cumplicidade ativa das instituições da UE) utilizaram a poupança dos portugueses e o crédito que pediram no estrangeiro em atividades especulativas (no setor financeiro e nos negócios escuros das PPP, por trás dos quais está a banca) e aplicaram o resto nos setores 'protegidos' que lhes garantem mais lucros (verdadeiras rendas), com destaque para os setores de bens não-transacionáveis (imobiliário, distribuição, energia, infra-estruturas, obras públicas).

Graças a este 'esforço', os bancos portugueses ficaram sem liquidez para conceder crédito à economia, e perderam a capacidade de se financiar no mercado interbancário, passando o BCE a ser o seu único financiador (aceitando como garantia títulos da dívida pública portuguesa). Foi a banca privada que, em março/2011, invocando falta de liquidez, 'impôs' ao Governo a decisão de recorrer à 'ajuda' do 'grupo financeiro' FMI-UE-BCE. Agora, obrigam o povo português a pagar a conta, argumentando que todos temos de assumir que gastámos mal o dinheiro e que todos vivemos acima das posses (estado, empresas e famílias)!

13. Perante a crise do euro (e crise da 'Europa'), prevaleceu, até hoje, a tese de que ela se deve aos 'pecados' dos povos do

${ }^{62}$ Cfr. Relatório da IAC, cit., 11. 
sul e a tese de que tal 'doença' se cura pela penitência e pelo sacrificio purificador, que anda de par com essa outra tese da austeridade regeneradora. ${ }^{63}$ Como muitos entenderam que para se ser bem visto nesta 'Europa alemã' era necessário não ser (ou, pelo menos, não parecer) 'pecador', assistiu-se ao deprimente espetáculo de ver os governantes irlandeses a jurar que a Irlanda não era Portugal, os portugueses a jurar que Portugal não era a Grécia, os espanhóis a jurar que a Espanha não era Portugal, os italianos a jurar que a Itália não era a Espanha, os franceses a jurar que a França não era a Itália... A União Europeia transformou-se numa melodramática desunião europeia.

Esta 'leitura' da crise e as políticas adotadas para a enfrentar estão a destruir as economias europeias, estão a romper o tecido social dos estados europeus, estão a desperdiçar uma geração (os jovens desempregados, quatro em cada dez); podem acelerar o fracasso da "fantasia" da UEM e do euro (nomeadamente do euro enquanto moeda de referência nos pagamentos internacionais, capaz de pôr cobro ao monopólio do dólar) e podem mesmo pôr em causa a Europa de paz que se pretendeu construir com a criação da CECA (uma Europa desejosa de integrar, sem riscos, uma Alemanha europeia, uma Alemanha despida de projetos imperiais e solidária com os interesses de todo o Velho Continente).

Em 1953, falando em Hamburgo para estudantes universitários alemães, Thomas Mann exortava-os, precisamente, a construir uma Alemanha europeia e a rejeitar a ideia de uma Europa alemã. Este apelo foi recordado, recorrentemente, logo após a 'reunificação' da Alemanha. Hoje, não faltam razões para temer que este apelo se tenha esfumado. Em novembro de 2011, o secretário-geral do partido da Chanceler da Ale-

${ }^{63}$ Sobre as políticas de austeridade, ver A. J. Avelãs Nunes, “Apontamento..., cit. 
manha declarava num Congresso do seu partido que "agora na Europa fala-se alemão". Mais recentemente, o consagrado sociólogo alemão Ulrich Beck veio confirmar o que é visível por todos: "a crise do euro tem levado à emergência - até agora constante - da Europa alemã. (...) A Europa tornou-se alemã", mas "dizê-lo abertamente significa quebrar um tabu". ${ }^{64}$

Vistas as coisas de outro ângulo, a Alemanha, cada vez mais alemã, parece ter perdido "a consciência de uma herança histórico-moral comprometedora", "visão que marcou durante meio século a história do pós-guerra na Europa", ditando, por parte da Alemanha, uma atitude de "moderação diplomática e disponibilidade para adotar também as perspetivas dos outros". ${ }^{65}$ E a Europa alemã, 'governada' por esta Alemanha alemã, que esqueceu a "cultura de moderação" que adotara até há poucos anos e que coloca acima de tudo os interesses da Alemanha, "viola as condições fundamentais de uma sociedade europeia na qual valha a pena viver". Quem o afirma é Ulrich Beck.

O novo poder da Alemanha, nesta Europa à deriva, que parece perdida na história, está, com razão, a assustar muita gente. As preocupações a este respeito vêm de vários setores. Joschka Fisher, antigo ministro alemão dos Negócios Estrangeiros, parece ser uma das pessoas preocupadas: "A Alemanha destruiu-se - a si e à ordem europeia - duas vezes no século XX. (...) Seria ao mesmo tempo trágico e irónico que uma Alemanha restaurada $(. .$.$) trouxesse a ruína da ordem euro-$ peia pela terceira vez". ${ }^{66}$

Pessoalmente, perante as dificuldades por que passa o povo grego, impressiona-me muito o comportamento do governo alemão e da opinião pública alemã, que já acon-

\footnotetext{
${ }^{64}$ Cfr. U. BeCK, ob. cit., 11, 89 e 111.

65 Cfr. J. Habermas, ob. cit., 163-169.

${ }^{66}$ Apud J. A. Fernandes, Público, 11.8.2012.
} 
selharam os gregos a vender o Parténon e as ilhas do Mar Egeu. A Alemanha não pode esquecer que foi ela o devedor menos cumpridor da história do século XX, tratando-se, ainda por cima, de dívidas contraídas em associação com a prática de crimes gravíssimos contra os povos da Europa e de todo o mundo (crimes conta a humanidade). Não pode esquecer que mais de um milhão de gregos foram mortos em 1940 pelas tropas nazis, que causaram também ao povo grego enormes prejuízos materiais, sem contar com a pilhagem de obras de arte sem preço. Não pode esquecer que, oito anos apenas depois do fim da 2. ${ }^{a}$ Guerra Mundial, vários países (entre os quais a Grécia, a Espanha e a Irlanda) acordaram em perdoar dívidas à Alemanha. ${ }^{67}$

${ }^{67}$ O chamado Acordo de Londres (assinado em 27.2.1953) reflete o acordo estabelecido entre a devedora Alemanha (uma dívida avaliada em 32 biliões de marcos) e 26 países credores (os principais eram os EUA, o RU, a Holanda e a Suíça). Os EUA propuseram o perdão total da dívida

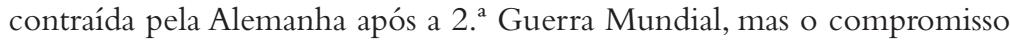
acabou por ser estabelecido nestes termos: a) perdão de $50 \%$ da dívida; b) redução considerável da taxa de juro; c) reescalonamento do pagamento dos restantes $50 \%$ para um prazo de trinta anos (algo mais para uma parcela desta dívida, de tal forma que a Alemanha só em 1990 pagou dívida contraída em 1920); d) o pagamento dos encargos da dívida seria feito apenas se houvesse saldo positivo da balança comercial da Alemanha, que não seria obrigada a recorrer a outros recursos (reservas de divisas ou dívida nova) se não registasse, em dado ano, aquele saldo positivo (para o conseguir, a Alemanha era mesmo autorizada a introduzir barreiras às importações); e) o pagamento efetivo dos encargos da dívida foi condicionado à capacidade de pagamento da Alemanha, não podendo o serviço da dívida absorver mais do que $50 \%$ do valor das exportações, e admitindo-se a suspensão dos pagamentos e a sua renegociação em caso de dificuldades económicas; $f$ ) os credores obrigavam-se a permitir à Alemanha garantir de forma duradoura o crescimento da sua economia e a sua capacidade de negociação; $\boldsymbol{g}$ ) o objetivo global do Acordo era o de permitir à Alemanha condições para prosseguir o crescimento económico sem sacrificar o consumo dos alemães. 
Os jornais gregos e alemães vêm falando de um relatório ainda secreto (mandado elaborar pelo Ministério das Finanças da Grécia) que estima os danos causados à Grécia em mais de 160 mil milhões de euros. Chegava para resolver os problemas financeiros da Grécia, que refletem, aliás, ganhos fartos do capital alemão. Sabendo que a Alemanha nunca pagou à Grécia um cêntimo que fosse para indemnizar o povo grego dos danos que lhe causou, o Ministro das Finanças alemão - que está sempre a dar lições aos 'povos do sul', exigindo-lhes que paguem as suas dividas e impondo-lhes pesados sacrificios - vem agora dizer que a questão das reparações de guerra é assunto do passado. É uma arrogância que ofende o mundo inteiro, semelhante à daqueles que negam o holocausto.

Este mesmo ministro conhece certamente muito bem a história do sistema bancário alemão, recheada de episódios de corrupção e de gestão danosa. Talvez porque teve em conta (também) esta informação, o ministro reconheceu, no final de 2011 que "a cupidez e a procura de lucros cada vez mais elevados nos mercados de capitais" têm "responsabilidade na crise bancária e económica, e depois na crise de países inteiros, com a qual estamos confrontados desde 2008". Talvez essa cupidez dos bancos alemães tenha tido alguma responsabilidade na crise bancária que também afetou a Alemanha, cujos contribuintes tiveram de pagar, entre 2008 e 2012, segundo dados da Comissão Europeia, 646 mil milhões de euros para salvar bancos alemães à beira da falência, o que faz da Alemanha o país que mais gastou, a seguir ao Reino Unido, para não deixar falir bancos irresponsáveis (ou criminosos), mas too big to fail. ${ }^{68}$

A História ensina que há muitas formas de resolver os mesmos problemas. E a Alemanha deveria estar entre os primeiros países a não esquecer as lições da História.

${ }^{68}$ Cfr. Les Échos, 16.12.2011, e Público, 25.8.2013. 
O ministro alemão deve saber que a cupidez é um 'pecado', mas tem sido um dos pregadores mais inflamados na difusão da tese de que a (inventada) crise da dívida soberana dos povos do sul é fruto, não do 'pecado' da cupidez da banca, mas dos 'pecados' dos povos do sul, povos preguiçosos que se habituaram a viver acima das suas posses. Por isso o ministro das finanças alemão entende que estes povos têm de ser 'castigados' com duras 'penitências', para expiarem os seus 'pecados', esquecendo aquilo que sabe muito bem: que o grosso da despesa que endividou os estados periféricos do sul da Europa (e mesmo países ricos como os EUA) representa o custo da salvação dos ativos dos muito ricos do topo e a banca arruinada pelos 'jogos de casino'. ${ }^{69}$

A "paixão europeia pela austeridade" de que fala Paul Krugman (ou a "fixação europeia na austeridade" a que se refere Mark Blyth) alimenta-se desta 'teologia' perversa. E também por aqui se explica que, quando se tratou de 'ajudar' os povos do sul em dificuldade, a Alemanha e a UE, comandada pela Alemanha, lhes tenham emprestado dinheiro a juros agiotas. Sabemos que o BCE tem ganho milhares de milhões de euros nos negócios com os títulos da dívida pública dos países do sul. Em 2012, o BCE aceitou devolver à Grécia mais de três mil milhões de euros que tinha ganho em operações sobre títulos da dívida pública grega. E a Alemanha aproveitou igualmente a crise resultante da cupidez dos bancos para ganhar dinheiro à custa dos povos do sul. Segundo os jornais, a Alemanha tinha ganho, até então, com os negócios sobre a dívida soberana dos povos do sul, 41 mil milhões de euros. ${ }^{70}$

Compreende-se agora a razão por que foi 'inventada' a crise das dívidas soberanas e confirma-se que quem está a pagar

${ }^{69}$ Cfr. M. Bцyтн, ob. cit., 35.

${ }^{70}$ Ver Expresso, 24.8.2013. É claro que tanto o BCE como a Alemanha ganharam também muito dinheiro com os negócios sobre títulos da dívida pública portuguesa. 
o preço desta crise não são os contribuintes alemães (que só pagaram para tapar os buracos do seu próprio sistema bancário), mas os 'colonizados' povos do sul. Malhas que o império tece... O ministro alemão sabe tudo isto (e muito mais) muito melhor do que eu. E talvez também saibam tudo isto os 'comentadores' que, no nosso País, vão todos os dias à TV dizer que temos de 'comer e calar', porque os contribuintes alemães podem perder a paciência e deixar de pagar os 'pecados' (ou os vícios) dos povos do sul. É um espetáculo pouco dignificante aquele a que vamos assistindo nestes tempos do capitalismo do crime sistémico organizado, nestes tempos em que o "dinheiro organizado" comanda e controla os grandes centros produtores e difusores da ideologia dominante, nomeadamente os poderosos meios de comunicação social de massas.

14. As políticas de austeridade regeneradora que têm sido impostas, desde 2008/2009, a pretexto de pôr cobro à crise do euro (disfarçada de crise das dívidas soberanas dos países do sul) têm agravado a situação criada pelo euro. $\mathrm{O}$ governo português previu que, entre janeiro/2011 e dezembro/2013, a austeridade atingisse 20 mil milhões de euros, metade através de cortes na despesa pública e metade pela via do aumento das receitas fiscais, para que, durante a aplicação do programa da troika, se anulasse o défice das contas públicas e se passasse para uma situação de excedente. Os dados disponíveis apontam para uma redução da despesa pública de 6,2 mil milhões de euros e uma redução da receita fiscal de 200 milhões de euros (apesar do "brutal aumento dos impostos": novos impostos, taxas mais elevadas, sobretaxas adicionais). E algumas das medidas extraordinárias tomadas, como a transferência para o estado dos fundos de pensões da banca, constituíram um novo e pesado encargo para a Segurança Social, que, entretanto, não recebeu o dinheiro daqueles fundos, desde sempre insuficientes para satisfazer os encargos respetivos. 
Como era de esperar, as receitas não acompanharam a subida das taxas dos impostos.

O corte dos salários e das pensões dos trabalhadores do estado provocou, diretamente, a quebra das receitas do IRS e, indiretamente, a diminuição do rendimento disponível das famílias, a baixa do consumo privado, e, portanto, a redução da receita do IVA (apesar do aumento brutal da respetiva taxa). Efeitos idênticos resultaram do aumento dos impostos. Por outro lado, a diminuição da procura interna provocou a baixa do PIB, com a consequente quebra do investimento, a falência de muitas empresas, o aumento do desemprego, o aumento das despesas sociais e a diminuição da receita dos descontos para a Segurança Social e para a CGA.

Foi um sacrificio enorme imposto a quem trabalha (os que sofreram os cortes na despesa pública e pagaram os impostos), para obter um resultado muito aquém do proclamado. A verdade é que, no triénio 2011-2013, consegue-se reduzir o défice das contas públicas de cerca de $9 \%$ do PIB para 5,5\% do PIB, mas à custa do aumento da dívida pública de $35 \%$ (cada euro da austeridade provocou um aumento de 8,5 euros na dívida pública) e da diminuição do PIB de 4,3\% (1,2 euros a menos no PIB por cada euro da austeridade). Melhorou um pouco a situação da balança de pagamentos correntes, graças ao aumento das exportações (mas o turismo beneficiou de circunstâncias ocorridas em mercados concorrentes particularmente favoráveis para nós, e o aumento da exportação de produtos refinados da GALP compensa e encobre a quebra das exportações em outros setores) e à diminuição das importações (que significa, em boa verdade, desinvestimento, que iremos pagar caro...).

Como pano de fundo, pagámos o preço da diminuição contínua do número de postos de trabalho (é cada vez mais reduzido o número de portugueses em atividade), do aumento significativo do desemprego (e do número de 
desempregados de longa duração e de idade mais avançada, que não recebem qualquer apoio do estado e já desistiram de se inscrever nos serviços do Instituto do Emprego, aliviando as estatísticas de desemprego) e da emigração forçada de centenas de milhares de portugueses (sobretudo jovens habilitados com cursos superiores, que não constam das estatísticas do desemprego porque emigraram), da redução dos salários (e consequente aumento do número dos pobres que trabalham) e das pensões, do empobrecimento de milhões de portugueses (apenas compensados pela alegria de verem aumentar, a cima da média europeia, o número dos e a fortuna dos multimilionários pátrios). ${ }^{71}$

71 Segundo os dados dos orçamentos do estado para 2011, 2012 e 2013, as despesas com prestações sociais terão diminuído cerca de 3.250 milhões de euros. Daqui resultou o congelamento das pensões (mesmo das mais baixas), a redução do montante do subsídio de desemprego e do período durante o qual ele é assegurado, a diminuição do número de desempregados que recebem apoio do estado, a diminuição do número de crianças que recebem abono da família (quase 600 mil a menos), a diminuição do número de beneficiários do complemento solidário de idoso, a redução do número de beneficiários do rendimento social de inserção. Isto num país em que, segundo dados do INE, cerca de 2 milhões de pessoas são consideradas pobres e mais de 4 milhões cairão na pobreza se faltarem as prestações sociais do estado. Num país em que, em 2010, a despesa per capita em prestações sociais era de 3515 euros (6.258 euros para a UE/27) e em que as prestações sociais correspondiam a $26,9 \%$ do PIB (29,4\% para a UE/27 e 30,4\% para a UE/17). O euro e as políticas de austeridade dele resultantes estão a afastar-nos da Europa, em vez de nos colocar no "pelotão da frente". Ver E. RosA, “As verdadeiras..., cit.

O Eurostat divulgou em 5.12.2013 estudos que indicam que a percentagem de pessoas em situações de pobreza aumentou nos 28 países da UE de 23,7\% da população em 2008 para 24,8\% em 2012 (no total, estamos a falar de 124,5 milhões de pessoas). Em Portugal esta percentagem está acima da média da UE, afetando 2,7 milhões de pessoas (mais, segundo o Prof. Alfredo Bruto da Costa, em declarações à Agência Lusa, desde logo porque o inquérito do Eurostat não abrange os idosos e outras pessoas que vivem em instituições). Mas a pobreza aumentou em 
No OE/2014, o governo insiste na mesma política, prevendo um programa de austeridade de 4,2 mil milhões de euros (3,2 mil milhões de cortes nos salários e nas pensões dos trabalhadores da administração pública e mil milhões de euros de aumento da receita). É mais um pesadíssimo sacrifício para se conseguir alcançar a meta imposta pela troika de um défice das contas públicas de 4\% em 2014, meta que ninguém acredita seja alcançada, nem o governo (que propôs à troika 4,5\%), desde logo porque se pressupõe que o PIB cresça, em 2014, pelo menos $0,8 \% .^{72}$

Ora, prescindindo de outras considerações teóricas e empíricas, basta invocar a experiência dos últimos três anos para justificar todas as dúvidas sobre estas previsões. O mais certo é que o PIB não cresça (se é que não baixa, ainda que as exportações continuem a aumentar) e que o défice público continue acima dos $4 \%$ do PIB. A dívida pública continuará a aumentar e o crédito mal parado da banca perante as famílias e (sobretudo) perante as empresas, que tem vindo a crescer, poderá atingir níveis suscetíveis de ameaçar a solvabilidade dos bancos portugueses. Os juros da dívida continuarão a absorver uma parte crescente do PIB, condenando os portugueses a uma espécie de escravidão por dívidas.

Mais grave ainda: Portugal sofre um processo de empobrecimento acelerado, que ameaça hipotecar o futuro. Somos um país mais pobre, mais 'velho' (a taxa de natalidade baixa; a emigração de jovens está a 'roubar-nos' uma geração), com menos saúde (a taxa de mortalidade pela tuberculose aumentou; a taxa de mortalidade infantil tem aumentado desde 2010), menos confiante e menos preparado (emigram os mais qualificados; o abandono escolar tem vindo a aumentar;

17 dos 28 estados-membros da UE, mesmo em países como a Espanha (aumentou de 24,5\% em 2008 para 28,2\% em 2012) e a Itália (aumento de $25,3 \%$ em 2008 para 29,9\% em 2012).

${ }^{72}$ Ver J. C. Caldas, ob cit. 
segundo dados da UE, 38\% dos jovens que queriam continuar a estudar não o podem fazer por razões económicas), um país que vem delapidando, nestes últimos três anos, o esforço feito no âmbito da investigação científica. Pela educação e pela saúde passa a igualdade de oportunidades, a possibilidade de aceder a postos de trabalho qualificado e bem pago, a capacidade para criar mais riqueza e para concorrer com os produtos estrangeiros. Pelo desenvolvimento da investigação científica e tecnológica passa a nossa capacidade de desenvolvimento autónomo, baseado em ganhos de produtividade.

15. Posta de lado na sequência da Grande Depressão, a tese da austeridade regeneradora renasceu há duas ou três décadas atrás e emergiu agora, com a força destruidora de um vulcão, depois da crise bancária que teve início nos EUA em 2007/2008 e que rapidamente contaminou toda a Europa. Entendida como "penitência" ("a dor virtuosa após a festa imoral"), a austeridade não é "uma dieta de dor que todos partilharemos. Poucos de nós são convidados para a festa, mas pedem-nos, a todos, que paguemos a conta". A austeridade - conclui Mark Blyth - "depende de os pobres pagarem os erros dos ricos".

Num livro importante em que estuda a história da "ideia perigosa" da austeridade e faz uma cuidada análise crítica das políticas de austeridade, Mark Blyth observa, porém, que "a austeridade é, em primeiro lugar e acima de tudo, um problema político de distribuição, e não um problema económico de contabilidade". ${ }^{73}$ E refere, a este propósito, estudos especializados feitos na Alemanha e nos EUA. No

73 Cfr. M. Bцyтh, ob. cit., 35. Neste livro o autor mostra quais os interesses que estas políticas visam proteger e mostra que há outras soluções (mesmo ficando apenas no plano da fiscalidade) para resolver os problemas do défice e da dívida. 
caso da Alemanha, conclui-se que um imposto cobrado uma única vez, a título excepcional, com uma taxa de $10 \%$ sobre a fortuna pessoal líquida dos que tivessem mais de 250 mil euros geraria uma receita correspondente a 9\% do PIB; se este imposto incidisse apenas sobre as fortunas superiores a 500 mil euros (2,3\% dos contribuintes), a receita equivaleria a $6,8 \%$ do PIB; se incidisse apenas sobre as fortunas superiores a um milhão de euros ( $0,6 \%$ dos contribuintes), o mesmo imposto geraria uma receita correspondente a $5,6 \%$ do PIB. ${ }^{74}$

74 Esta problemática da tributação excepcional dos muito ricos, sobretudo em situações de crise, foi várias vezes abordada, sobretudo nos EUA. No âmbito das medidas para o financiamento da participação americana na $1 .^{a}$ Guerra Mundial, o Congresso chegou a discutir a aplicação de uma taxa de imposto de 100\% sobre os rendimentos anuais superiores a cem mil dólares (o equivalente, hoje, a um valor entre 2 milhões e dois milhões e meio de dólares). O projeto não vingou, mas em 1918 os rendimentos superiores a um milhão de dólares passaram a ser tributados a uma taxa de 77\%. Em 1942, agora tendo em vista o financiamento do esforço de guerra resultante da participação dos EUA na 2. ${ }^{a}$ Guerra Mundial, Roosevelt propôs que, enquanto durasse a guerra, o rendimento máximo não deveria ultrapassar 25 mil dólares (entre 300 e 400 mil dólares atuais). O Congresso não foi tão longe, mas, em 1944, fixou em 94\% a taxa do imposto sobre os rendimentos anuais superiores ao equivalente a 3 milhões de dólares atuais.

No contexto da presente crise, alguns americanos muito ricos têm-se 'queixado' de que pagam poucos impostos. E alguns especialistas propõem que o rendimento médio da elite dos mais ricos $(1 \%$ dos americanos) não possa ser superior a 36 vezes o salário médio. Seria uma medida interessante, se tivermos presente que o rendimento dessa elite (grandes acionistas, gerentes do topo, advogados de negócios) é cerca de 300 vezes superior ao salário médio na América (cfr. The New York Times,18.12.2011). Mas a realidade é muito diferente: em 2009, os 400 americanos mais ricos pagavam uma taxa de imposto sobre o rendimento de 19,9\%, embora auferissem um rendimento de 97 mil dólares por hora. $\mathrm{E}$ os que constituem os $1 \%$ mais ricos pagavam uma taxa à roda de $20 \%$, bastante abaixo da taxa cobrada aos titulares de rendimentos moderados (cfr. J. Stiglitz, O Preço..., cit., 11 e 28). 
No caso dos EUA, as conclusões são ainda mais impressionantes. Porque a concentração do rendimento vem atingindo níveis escandalosos. ${ }^{75}$ Ainda nos EUA, calcula-se

Em Portugal, os bem-pensantes nem querem ouvir falar deste assunto. No entanto, seria interessante fazer as contas. Um imposto extraordinário de solidariedade, com uma taxa de 10\% (a contribuição extraordinária de solidariedade que incide sobre algumas pensões dos aposentados da CGA é superior a esta!), cobrado sobre os cem mil milhões de euros que somam as fortunas dos nossos multimilionários daria ao estado uma receita de dez mil milhões de euros. Era uma solução mais justa, mais forte em termos de combate ao défice das contas públicas e muito mais favorável para a economia. Poderíamos também falar daqueles que pagam impostos na Holanda e daqueles que 'fogem', patrioticamente, para os paraísos fiscais. Há alternativas a esta austeridade. Ninguém de boa fé o pode negar.

Ainda no plano da fiscalidade, poderíamos recordar o nunca concretizado imposto sobre as transações financeiras. Se o mundo não fosse governado pelo capital financeiro, não se verificaria o verdadeiro absurdo de pagarmos imposto (a uma taxa de 23\%) quando compramos uma sopa num restaurante ou quando compramos o pão de cada dia e não pagarem qualquer imposto as transações sobre os chamados 'produtos financeiros'. À escala da UE, mesmo a uma taxa de 0,05\%, o Relatório Podimata calcula uma receita anual de 200 mil milhões de euros, montante que seria ainda mais elevado se fossem igualmente tributadas as transações sobre produtos financeiros derivados. Sobre esta problemática, ver o meu livro A Crise..., cit., 182-187.

75 Atualmente, os 1\% dos mais ricos dos EUA (que viram a sua situação melhorar sempre nas últimas três décadas) chamam a si $25 \%$ do rendimento nacional, o que significa que os 400 mil americanos mais ricos têm mais ativos do que os 150 milhões da base. A parte do rendimento arrecadado pelo 0,1\% dos mais ricos passou de 4,2\% em 1945 para 12,3\% em 2007. Entre 2000 e 2007, os 1\% mais ricos apoderaram-se de $75 \%$ da riqueza criada (em 2007, esta 'aristocracia' detinha cerca de $2 / 5$ da riqueza nacional). É obra! Só um exemplo: os seis membros da família proprietária do império da Walt-Mart têm uma fortuna que equivale a toda a 'riqueza' (ou pobreza) detida pelos 30\% mais pobres entre os americanos. Nos últimos trinta anos, enquanto os salários médios estagnaram, os salários dos 1\% mais bem pagos aumentaram cerca de $150 \%$ e os dos 0,1\% do topo aumentaram mais de 300\%. Com a Administração Clinton começou a crescer a percentagem do rendimento adicional arre- 
que estejam abrigados em paraísos fiscais, sem pagar qualquer imposto, uns 32 mil biliões de dólares, o dobro do montante da dívida nacional dos EUA. É mais do que um escândalo. É um crime, o crime sistémico. É esta elite dos rendistas muito ricos (que enriquecem graças a políticas de exploração violenta da grande massa dos que vivem do rendimento do seu trabalho e que fogem criminosamente ao cumprimento dos seus deveres de cidadania, ajudados pela grande banca e pelo 'seu' estado) que insistentemente justifica a austeridade e a sua inevitabilidade como solução para os problemas resultantes do excesso de despesa (porque andámos, todos, a viver acima das nossas posses), esquecendo "o facto de essa 'despesa' ter sido o custo de salvar os seus ativos à custa do erário público".

Com efeito, na definição de Mark Blyth, a austeridade é "uma forma de deflação voluntária em que a economia se ajusta através da redução dos salários, preços e despesa pública para restabelecer a competitividade, que (supostamente) se consegue melhor cortando o orçamento do estado, as dívidas e os défices". Os seus defensores entendem que ela inspirará “confiança empresarial", e esta, como uma espécie de varinha mágica, promoverá o crescimento económico e resolverá todos os problemas. ${ }^{76}$

Em junho/2010, Jean-Claude Trichet, um verdadeiro 'papa' do neoliberalismo e então Presidente do BCE, dizia ao jornal La Repubblica: "No que diz respeito à economia, a ideia de que as medidas de austeridade podem

cadada pelos $1 \%$ mais ricos (chegou a $45 \%$ ); aumentou ainda mais com o governo de G. W. Bush (65\%), sendo que a 'crise' e as políticas de 'combate à crise' permitiram que, em 2010, os 1\% mais ricos arrecadassem 93\% do rendimento adicional criado nesse ano (só os $0,1 \%$ mais ricos arrecadaram 37\%), feito que teve como contrapartida a redução de cerca de $40 \%$ da riqueza da classe média. Os dados referidos nesta nota foram colhidos em M. Blyth, ob. cit., 33/34 e 356-358, J. Stiglitz, O Preço..., cit., 11 e 60-67 e W. STreeck, ob. cit., 93.

76 Cfr. M. Bцyтh, ob. cit., 16, 29 e 32. 
levar à estagnação é incorreta". Tinha razão: levaram à recessão, que é muito pior do que a estagnação. Que o digam a Grécia, a Irlanda, Portugal e outros países vítimas da 'guerra santa' contra eles desencadeada pelos Trichet-fiéis-da-austeridade-regeneradora.

Para espanto do mundo (ou talvez não), o FMI reconheceu há tempos que errou ao calcular o chamado multiplicador fiscal (ou multiplicador da austeridade), em especial no que se refere a Portugal. Pressupôs o FMI que cada euro de austeridade (cada euro a menos no défice orçamental) provocaria 50 cêntimos de recessão (de diminuição do PIB), tendo vindo a concluir que, afinal, cada euro de austeridade arrasta uma diminuição do produto entre 90 e 170 cêntimos.

Se se tratasse de um erro, estaríamos perante um caso de incompetência grosseira. Porque de muitos lados se ouviram vozes autorizadas a prever o que veio a acontecer. E porque é dos livros que, mesmo para os que acreditam na tese da austeridade expansionista (que os estudos empíricos não confirmam), políticas deste tipo devem ser evitadas numa situação de crise financeira e económica global e não devem ser aplicadas simultaneamente em vários países que são importantes parceiros comerciais uns dos outros (porque os efeitos recessivos verificados em um deles desencadeiam e reforçam efeitos recessivos nos demais). ${ }^{77}$

A Diretora-Geral do FMI farta-se de falar da "fadiga da austeridade", mas impõe-na, sem contemplações, em do-

77 Trata-se de transpor para esta situação o raciocínio que justifica o chamado paradoxo da poupança keynesiano: em um dado país, se todos pouparem ao mesmo tempo não haverá consumo que alimente a procura e estimule o investimento. Pois bem. Do mesmo modo, no âmbito de uma comunidade de estados como a UE, a aplicação de políticas de austeridade em vários países ao mesmo tempo, 'seca' o mercado interno (que absorve grande parte das exportações no seio da UE), provocando recessão e desemprego. 
ses letais, aos povos 'condenados' a executar 'programas de ajustamento'. Talvez a austeridade esteja 'fatigada', mas os 'austeritários' que mandam nas troikas obrigam-na a ir à luta, para martirizar os povos, com o pretexto de reduzir a dívida pública (que, por pura teimosia, persiste em aumentar na sequência das tais políticas de ajustamento). Já em meados de dezembro/2013, a mesma responsável afirmou publicamente que Portugal e a Grécia têm sofrido austeridade a mais e que ambos os países deveriam ter tido mais tempo para ajustar as contas públicas. São brincadeiras de mau gosto por parte de uma instituição que continua a impor-nos a mesma austeridade draconiana, destruindo a nossa economia e a empobrecendo o nosso povo. Tais afirmações servem para quê? Para nos humilhar? Não é possível respeitar quem reconhece os erros e diz às suas vítimas da sua incompetência e da sua prepotência: estais a sofrer as consequências dos meus erros, mas eu quero que continueis a sofrer, porque me apetece. É pura malvadez.

O mais grave é que este comportamento parece corresponder a uma estratégia estudada por parte dos responsáveis do FMI. Na verdade, o FMI defendeu com unhas e dentes, em meados dos anos 1990, as políticas de austeridade que impôs a alguns países asiáticos, exigindo-lhes que conseguissem rapidamente um orçamento equilibrado, apesar de se saber, como salienta Joseph Stiglitz, que, "durante sessenta anos, nenhum economista respeitável admitiu que uma economia que se encaminha para uma recessão deve ter um orçamento equilibrado". Em 1998 viria a público reconhecer que a receita aplicada a esses países tinha sido demasiado austera. Agora, faz o mesmo discurso, mas continua a impor as mesmas políticas de austeridade, não querendo aprender nada com a crise asiática dos anos 1990, que deixou muito claro este resultado: "os países que recusaram as restrições impostas pelo FMI cresceram mais rapidamente, com mais igualdade e 
mais redução da pobreza do que aqueles que obedeceram às suas ordens" e cumpriram os programas de austeridade. ${ }^{78}$

16. Alguns esforçam-se por fazer crer que as políticas de austeridade não têm responsáveis: elas são, pura e simplesmente, inevitáveis, porque é inevitável reduzir (ou anular) o défice das contas públicas e diminuir a dívida pública. O Comissário Europeu Olli Rehn tem invocado uma justificação 'científica' (a melhor maneira de caucionar a 'pureza' das suas intenções e a correção das suas políticas), invocando uma teoria 'descoberta' por dois professores de Harvard (Carmen Reinhardt e Kenneth Rogoff), segundo a qual um país com uma dívida superior a $90 \%$ do PIB está condenado a sofrer uma redução do crescimento económico. ${ }^{79}$

Está hoje provado que esta 'teoria' não tem qualquer base sólida que a sustente (é a desgraça de muitas teorias quando são confrontadas com a realidade...). Mas ela continua a inspirar todos os Olli Rehn deste mundo. A austeridade não cessa de aumentar e, com ela, não têm diminuído (antes pelo contrário) nem a dívida nem o défice públicos, mas têm aumentado a recessão e o desemprego.

A vida tem mostrado, porém, que, além de injusta, a austeridade não funciona. As políticas de austeridade estão a falhar, não só em Portugal, mas em toda a Europa. E, no entanto, os mais altos responsáveis continuam a falar delas como se fossem não só inevitáveis mas também saudáveis para a economia.

Reconhecido o erro, que razão pode justificar que tanto o FMI como as instâncias europeias que integram a troika persistam nas políticas que consideram erradas? O mínimo

78 Cfr. J. Stiglitz, El Malestar..., cit., 141 e 308.

79 Carmen Reinhardt e Kenneth Rogoff, Growth in a Time of Debt, working paper 15.639, National Bureau of Economic Research, Cambridge (Mass), janeiro/2010. 
que se pode exigir a quem comete um erro e o reconhece é que cesse imediatamente a conduta errada e indemnize os que sofreram as consequências do seu erro.

Descontada a incompetência, fica de pé a atitude deliberada e fria de 'castigar' os povos do sul da Europa com sacrificios enormes, para salvar o euro de uma crise que deveria ter sido combatida com o contributo de todos os países da Eurozona, na proporção da sua riqueza e das vantagens que extraem do sistema da moeda única.

Mark Blyth não exagera quando sublinha que os custos da "arrogância epistemológica" e da "insistência ideológica" que caraterizam as políticas de austeridade "têm sido, e continuam a ser, horrendos". ${ }^{80}$ E Joseph Stiglitz mostra que, por toda a Europa, os países que adotaram políticas de austeridade, por sua iniciativa ou por imposição dos "mercados" (que fazem a 'guerra' por interpostas troikas), "entraram em recessões mais profundas, e, à medida que estas se aprofundavam, as melhorias esperadas no plano fiscal foram dececionantes". Confirma-se o que já se sabia: "praticamente não há exemplos de países que tenham recuperado de uma crise através da austeridade". 81

Sabendo tudo isto, como se compreende que os responsáveis das troikas (que Paul Krugman chamou, muito recentemente, "insolentes e delirantes") continuem fiéis à sua "paixão" de "prosseguir uma austeridade sem limites"? Esta "paixão pela austeridade" só pode justificar-se por razões ideológicas: destruir o estado social, difundir a cultura

${ }^{80}$ Cfr. M. BLyth, ob. cit., 22 e 29.

81 Cfr. J. Stiglitz, O Preço..., cit., 23. Nos EUA, políticas do mesmo tipo conduziram a que, cinco anos passados sobre a eclosão da crise, em 2008, um em cada seis americanos que querem ter um emprego a tempo inteiro não conseguem arranjá-lo; cerca de 8 milhões de famílias perderam as suas casas e 4 milhões foram despejadas (cfr. J. Stiglitz, últ. ob. cit., 59). 
do medo e alterar a favor do capital a estrutura das relações laborais, anulando a contratação coletiva, enfraquecendo os sindicatos, precarizando o emprego, facilitando e embaratecendo os despedimentos, reduzindo os salários e os direitos dos trabalhadores, aumentando o horário de trabalho, reforçando, em suma, a exploração dos trabalhadores.

17. Durante o período de debate público que antecedeu o referendo sobre o projeto da chamada Constituição Europeia, alguns antigos dirigentes do Partido Socialista francês (que, contra o seu partido, fizeram campanha pelo NÃO à dita 'constituição') vieram dizer verdades que não se ouviam antes, vindas de dentro do campo social-democrata.

Jean-Pierre Chevènement, várias vezes ministro de governos socialistas, caraterizou a 'esquerda' representada pelo PSF como "uma mescla de 'realismo económico', de anticomunismo renovado e de espírito social cristão", considerando-a a "convergência de fundo da esquerda social-liberal com a direita liberal em matéria de política económica e social". 82

Georges Sarre veio defender que "a Europa se transformou no joker de uma esquerda sem projeto nem reflexão", uma "esquerda que não tem outro projeto para além da construção europeia, a Europa", uma esquerda que, para ser credível e não assustar os mercados, defende e pratica "uma política ainda mais à direita do que a direita". ${ }^{83}$ E Jacques Généreux não hesitou em escrever que se ela [a tal 'constituição europeia'] fosse aprovada, "só as políticas de direita e conformes à lógica liberal seriam constitucionais". ${ }^{84}$

Em outubro de 2011 escreveu o porta-voz do Partido Socialista francês (Benoît Hamon, atual ministro do governo

${ }^{82}$ Citado por S. Halimi, “A esquerda governamental..., cit., 8/9.

83 Cfr. G. Sarre, ob. cit., 165-169.

${ }^{84}$ Cfr. Libération, 9.10.2003. 
Hollande): "Uma parte da esquerda europeia [a social-democracia europeia], à semelhança da direita, deixou de pôr em causa que é preciso sacrificar o estado-providência para restabelecer o equilíbrio orçamental e agradar aos mercados. (...) Fomos em vários lugares do mundo um obstáculo ao progresso". Feito o diagnóstico, acrescenta este dirigente socialista: "Não me resigno a isso".

Também em Portugal algumas vozes vindas do campo socialista sublinham que o ‘blairismo' não passa de uma “tentativa de conciliar o inconciliável e de justificar o injustificável" e reconhecem que os partidos socialistas e sociais-democratas europeus "perderam a alma e a coerência ideológica", não passando hoje de uma "variante social-democrata do neoliberalismo". Alguns admitem mesmo que a tendência dominante nos partidos que integram a Internacional Socialista é "a tendência neoliberal (...), que se traduz, basicamente, na aceitação do fundamentalismo do mercado". ${ }^{85}$

85 Este é o diagnóstico de Alfredo Barroso, ob. cit. Já em 2013, o economista e deputado eleito pelo PS na Assembleia da República João Galamba escreveu um artigo que confirma haver entre os socialistas e sociais-democratas portugueses alguns que não fogem aos problemas, não recusam enfrentá-los e analisá-los, colocando-se assim no caminho da compreensão da vida e da descoberta de soluções alternativas para as dificuldades que temos de enfrentar (porque a ideia de que não há alternativa é uma ideia que devia envergonhar os seus defensores). Vale a pena transcrever o último parágrafo desse artigo: "A moeda única, para funcionar, teria de ser uma federação, semelhante aos Estados Unidos da América. Isto é, teria de ter um verdadeiro orçamento federal, financiado por recursos próprios; teria de criar títulos de dívida europeia, para garantir estabilidade financeira; teria de institucionalizar mecanismos de transferências orçamentais, para garantir o mínimo de coesão territorial. E tudo isto já, e não daqui a uns anos. Como esta revolução institucional é simultaneamente impossível (não existem condições políticas para pôr em prática esse projeto) e necessária (sem essas reformas o euro não é sustentável), é difícil criticar o statu quo sem concluir que o problema reside, afinal, na existência da própria moeda única. Consequentemente, o único 
Perpassa por aqui a ideia de que é urgente arejar esta Europa construída "à porta fechada", deixando entrar por ela adentro a vontade dos povos da Europa, escorraçando os guardiões do templo neoliberal. Mas a tendência dominante da social-democracia europeia continua a comportar-se como uma verdadeira "esquerda choramingas", 86 a "esquerda" que lamenta, com uma lágrima ao canto do olho, o desem-

caminho desejável consiste em tentar desmantelar, de forma coordenada, a união monetária, sem pôr em causa o próprio projeto europeu. Não sei se esse projeto será possível, mas tenho a certeza de que será necessário, porque a alternativa é um desmantelamento desordenado e caótico, com consequências sociais, económicas e políticas devastadoras" (Cfr. J. Galamba, “Game Over”, cit.). Se bem interpreto o Autor, ele pressupõe que é necessário deitar fora o Tratado de Maastricht, o estatuto esquizofrénico do BCE, o PEC, o Pacto Orçamental e a regra de ouro. Pela minha parte, acrescentaria que o "próprio projeto europeu" precisaria também de ser passado a limpo.

${ }^{86}$ A expressão "esquerda choramingas" é de Frédéric LoRdon (“A desglobalização..., cit.), para caraterizar uma 'esquerda' que, segundo o autor, não está interessada em pôr em causa o que diz ser uma consequência inevitável da 'globalização': "a concorrência falseada entre economias com standards salariais abissalmente diferentes; a ameaça permanente de deslocalização; o constrangimento acionista que exige rentabilidades financeiras sem limites, de tal forma que a sua combinação opera uma compressão constante dos rendimentos salariais; o desenvolvimento do endividamento crónico das famílias que isso origina; a liberdade absoluta do sistema financeiro para desenvolver as suas operações especulativas desestabilizadoras, neste caso a partir de dívidas contraídas pelas famílias (como no caso dos subprime); o sequestro dos poderes públicos, instados a socorrer instituições financeiras enfraquecidas pelas crises recorrentes; o pagamento do custo macroeconómico destas crises pelos desempregados e ainda o seu custo para as finanças públicas pago pelos contribuintes, pelos utilizadores de serviços, pelos funcionários públicos e pelos pensionistas; a subtração aos cidadãos de qualquer forma de controlo da política económica, agora regulada unicamente pelas exigências dos credores internacionais, seja qual for o preço a pagar pelos corpos sociais; a transferência da gestão da política monetária para uma instituição independente, fora de qualquer controlo político". 
prego, a precariedade, as desigualdades e a exclusão social, mas que se recusa a identificar as suas causas estruturais, para não ter de as combater, levando tudo à conta da globalização incontornável (talvez a "globalização feliz" de que tanto se falou há uns anos atrás...), para a qual não há alternativa..., sendo mesmo apontada como "reacionária" qualquer ideia de desglobalização, i. é, de desmantelamento do império do grande capital financeiro. ${ }^{87}$

${ }^{87}$ Assim Pascal Lamy, em Le Monde, 1.7.2011. Todos recordaremos o discurso do candidato François Hollande, centrado na defesa do estado social e na guerra ao sistema financeiro. Pois bem. Ao anunciar, em 15.1.2014, o chamado Pacto de Responsabilidade, o Presidente François Hollande confirmou a sua fidelidade àquela que é já uma tradição de família da social-democracia europeia: fazer exatamente o contrário do que se promete aos eleitores. Certamente em nome da ideia de que "os custos indiretos do trabalho" (os descontos para a segurança social) "são um dos principais entraves ao crescimento do emprego" - ideia cara ao pensamento neoliberal e inspiradora do Pacto de Responsabilidade - Hollande e o seu Governo comprometem-se a eliminar, até 2017, a contribuição patronal que financia as prestações sociais em benefício das famílias (correspondente a $5,4 \%$ do salário). Conforme anunciou o Presidente francês em conferência de imprensa (ver os jornais) esta "redução dos custos do trabalho" destina-se a "simplificar e facilitar a vida das empresas", estimando-se que ela vai render ao capital cerca de 35 mil milhões de euros, retirados do financiamento do sistema público de segurança social. A justificação é a que resulta de todos os catecismos neoliberais: é preciso "facilitar a vida das empresas", para que elas possam criar mais postos de trabalho ("só conseguiremos reduzir o desemprego se as empresas criarem empregos”, proclamou o Presidente La Palisse). Em vez de, em termos keynesianos, redistribuir a riqueza para fortalecer a procura efetiva e estimular a atividade produtiva (e a criação de emprego), Hollande prefere a receita neoliberal: aumentar os lucros, na esperança de que daqui resulte o aumento do investimento e a criação de emprego novo. Esquece-se que o aumento dos lucros só se traduz em aumento do investimento se os potenciais investidores esperarem ver aumentar os seus lucros, o que só acontecerá se houver uma procura global capaz de adquirir, a um preço compensador, os bens que são produzidos para ser vendidos. Se a procura não for suficiente para absorver toda a oferta, estamos 
É uma visão filha do entendimento da globalização como uma consequência necessária, mecânica, fatal do desenvolvimento científico e tecnológico. ${ }^{88}$ Mas esta é uma 'leitura' amiga do grande capital financeiro, que é o grande impulsionador (e o único aproveitador) da política de globalização neoliberal e o autor e difusor desta visão ideológica (distorcida) sobre a natureza e o significado da globalização. Carregando nas tintas para sublinhar bem a minha ideia, direi que 'acreditar' na autenticidade deste retrato da globalização é o mesmo que acreditar que o lançamento das bombas atómicas sobre Hiroshima e Nagasaqui foi uma consequência inevitável do desenvolvimento científico na área da Física Nuclear e que a utilização maciça de armas químicas contra o povo vietnamita durante a Guerra do Vietnam foi uma consequência incontornável do desenvolvimento científico na área da química.

Estes crimes de guerra (verdadeiros crimes contra a humanidade) foram decisões políticas tomadas no quadro da política imperialista dos EUA. O lançamento das bombas atómicas

perante uma situação de sobreacumulação (de sobre-investimento), que gera sobreprodução (i.é, que gera crises de sobreprodução, crises de realização da mais-valia, crises que destroem o capital excedente, reduzem a produção e aumentam o desemprego). Antecipando a crítica de que o seu Pacto de Responsabilidade vai reduzir os meios de financiamento da segurança social, Hollande invoca um argumento digno de Rajoy, Passos Coelho, Cameron ou Merkel: vou fazer uma reforma do estado, simplificando a política tributária, reduzindo a despesa pública, lutando contra a fraude na segurança social (entre nós houve quem privilegiasse a fraude dos beneficiários do rendimento social de inserção...), o que permitirá poupar $53 \mathrm{mil} \mathrm{mi-}$ lhões de euros. Está-se mesmo a adivinhar quem vai fazer o sacrifício desta poupança: os trabalhadores e aposentados do costume. Como as troikas estão mal vistas, é preciso acabar com as troikas. O socialista-austeritário Hollande faz o papel da troika.

88 Já fiz a crítica desta visão ideológica da globalização em trabalhos anteriores: "Neoliberalismo, globalização..., cit; Neoliberalismo e Direitos Humanos, cit.; O estado capitalista..., cit; A Crise..., cit., 20ss e 266ss. 
foi o primeiro ato da Guerra Fria e visou intimidar a URSS e utilizar o monopólio da arma nuclear para impor os EUA como potência hegemónica à escala mundial. Em ambos os casos, o objetivo proclamado foi o de livrar o "mundo livre" da 'ameaça comunista'. ${ }^{89}$

Foram projetos falhados, porque em novembro/1949 a URSS ensaiou com êxito a primeira bomba atómica, e em 1957, com o lançamento do satélite artificial Sputnik, colocou-se na vanguarda da exploração do espaço e do conhecimento científico em vários domínios. À escala mundial, desenvolveu-se uma poderosa comunidade de países socialistas, cujo auxílio foi decisivo na luta dos povos contra o colonialismo e o imperialismo. A humilhante derrota infligida pela guerrilha vietnamita às todo-poderosas forças armadas americanas obrigou os EUA a aceitar a paz (1974). Foi o fim dos impérios coloniais, que teve o seu estertor com o 25 de Abril (a derrota do colonial-fascismo em Portugal), a vitória dos movimentos de libertação das antigas colónias portuguesas, o reconhecimento internacional da independência

${ }^{89}$ Os poderosos interesses daquilo que Eisenhower viria a designar por complexo militar-industrial impuseram a política militarista, apesar da oposição dos membros mais destacados da comunidade científica americana e mundial, com destaque para Albert Einstein, que em 1946 se pronunciava deste modo: 'É apavorante perceber que o veneno do militarismo ameaça trazer mudanças indesejáveis à atitude política dos Estados Unidos. (...) O que estamos vendo não é uma expressão de sentimentos do povo norte-americano; pelo contrário, reflete a vontade de uma poderosa minoria que usa a sua força económica para controlar os órgãos da vida política. Se o governo se mantiver nesse curso catastrófico, nós, cientistas, devemos recusar a submissão às suas exigências imorais, ainda que apoiadas por aparato legal. Existe uma lei não escrita, a da nossa consciência, que é muito mais impositiva que qualquer outra que venha a ser inventada em Washington. E, naturalmente, existem armas definitivas à nossa disposição: a não cooperação e a greve". É claro que, para Einstein, o desenvolvimento científico não é a causa da política imperialista, nem esta é uma consequência fatal daquele. Como poderia ser? 
dos novos países africanos e a derrota do apartheid na África do Sul.

A verdade, porém, é que a Guerra Fria forçou a corrida aos armamentos e colocou o mundo numa situação de equilíbrio pelo terror, que forçou a coexistência pacífica entre as duas grandes superpotências. E a militarização das economias traduziu-se em enorme desperdício de recursos desviados para o 'negócio' da morte, em vez de servirem a vida e o bem-estar da humanidade (recursos financeiros, conhecimento científico, mão-de-obra qualificada, recursos materiais).

$\mathrm{Na}$ minha ótica, a política de globalização neoliberal é isto mesmo: uma política ao serviço do objetivo do grande capital financeiro de 'governar o mundo' (de dominar o mundo), uma política inspirada nos princípios da contra-revolução monetarista (Hayek, Milton Friedman...) e nos dogmas da ideologia neoliberal, uma política que tem procurado submeter os trabalhadores à ditadura do capital financeiro.

Numa linguagem moderada (quase envergonhada por remar contra a corrente), Joseph Stiglitz vai dizendo a sua verdade de descontente com a globalização. ${ }^{90} \mathrm{E}$ defende que a "globalização assimétrica" que aí temos corresponde aos interesses das grandes empresas que vivem de rendas (rent-seeking), que "condicionaram a máquina política", conseguindo que os estados "definissem as regras da globalização de forma a aumentar o seu poder negocial com os trabalhadores" e a reduzir os impostos pagos por elas. Tudo a partir da consagração do princípio da liberdade absoluta de circulação de capitais. "Imaginemos, por um momento - escreve ele -, como seria o mundo caso houvesse livre mobilidade da força de trabalho, mas nenhuma mobilidade do capital". E a sua resposta é esta: "Os países competiriam para atrair trabalha-

${ }^{90}$ Ver El Malestar..., cit. 
dores. Prometeriam boas escolas e um bom ambiente, assim como impostos altos sobre o capital". ${ }^{91}$

Mas a "globalização assimétrica" foi desenhada ao contrário: o mundo em que vivemos favorece o grande capital financeiro, porque este mundo e as políticas que o puseram e o mantêm de pé foram moldados pelo poder político ao seu serviço. "A globalização, tal como tem sido defendida, parece frequentemente substituir as antigas ditaduras das elites nacionais por novas ditaduras das finanças internacionais". Por isso ele propõe uma "globalização de rosto mais humano", assente em "políticas para um crescimento sustentado, equitativo e democrático", porque "esta é a razão do desenvolvimento", porque, a seu ver, "o desenvolvimento consiste em transformar as sociedades, melhorar as vidas dos pobres, permitir que todos tenham oportunidade de progredir e de aceder à saúde e à educação". ${ }^{92}$

Também esta política de globalização neoliberal tem recorrido a "armas de destruição maciça" (Warren Buffet), nomeadamente os chamados produtos financeiros derivados, que têm alimentado a especulação (especulação sobre esses 'produtos', especulação sobre matérias-primas, sobre combustíveis, sobre alimentos, especulação, enfim, sobre a vida de milhões de pessoas) e toda a espécie de práticas criminosas (venho falando do capitalismo do crime sistémico), através das quais o grande capital financeiro vem condenando povos inteiros ao empobrecimento acelerado, cortando os direitos e os rendimentos dos trabalhadores, condenando ao desemprego

${ }^{91}$ Cfr. O Preço..., cit., 127.

92 Cfr. El Malestar..., cit, 308 e 313, onde escreve a seguir: "O desenvolvimento não consiste em ajudar uns poucos indivíduos a enriquecer ou em criar um punhado de indústrias protegidas que só beneficiam a elite do país; não consiste em trazer Prada e Benetton, Ralph Lauren ou Louis Vuitton para os ricos das cidades, abandonando à sua miséria os pobres dos campos". 
e à precariedade quase metade dos jovens, aumentando o número dos pobres que trabalham, agravando a exclusão social. É uma 'guerra' (uma guerra civil, uma guerra de classes à escala mundial) que produz em cada ano, neste tempo em que os ganhos da produtividade permitem a criação de riqueza a níveis até há pouco insuspeitados, tantas vítimas da fome ou de doenças causadas pela fome quantos os mortos da $2 .{ }^{a}$ Guerra Mundial.

Esta é a verdadeira natureza da globalização. O desenvolvimento científico e tecnológico, como a história tem demonstrado, é o caminho da libertação do homem, não é o caminho da escravidão. $O$ desenvolvimento científico e tecnológico não pode ser 'culpado' da globalização, porque esta não é uma consequência inevitável dele. A "esquerda de direita" que não quer compreender o que significa a globalização corre o risco de "quem nunca quer questionar nada": "o risco de nunca entender nada". ${ }^{93}$

Acredito que os responsáveis por esta 'guerra' estão igualmente condenados à derrota. Já em 23.9.2000 The Economist escrevia em editorial: "Os que protestam contra a globalização têm razão quando dizem que a questão moral, política e económica mais urgente do nosso tempo é a pobreza do Terceiro Mundo. E têm razão quando dizem que a onda de globalização, por muito potentes que sejam os seus motores, pode ser travada. É o facto de ambas as coisas serem verdadeiras que torna os que protestam contra a globalização tão terrivelmente perigosos". Num momento de lucidez, um dos faróis do neoliberalismo veio dizer o que nós já sabíamos: os motores da globalização neoliberal podem ser parados ou mesmo postos a andar em marcha atrás; a inevitabilidade da globalização neoliberal é um mito; a tese de que não há alternativa é um embuste.

93 Cfr. F. Lordon, "Sair do euro, mas como?”, cit., 12. 
É importante que alguém com a autoridade académica de Stiglitz venha dizer que a tese de que não há alternativa é apenas o fruto da sementeira feita pelo grande capital: "os $1 \%$ trabalharam muito para convencer os restantes de que um mundo alternativo não é possível, de que fazer alguma coisa que os $1 \%$ não desejam irá inevitavelmente prejudicar os 99\%". Contra este mito, vem defender que "podemos ter realmente uma economia mais dinâmica e eficiente $e$ uma sociedade mais justa". ${ }^{94}$ Numa perspetiva reformista, propõe um "contrato social para o século XXI", uma "agenda de reforma económica", capaz de promover a mesmo tempo " a eficiência económica, a equidade, a produção e as oportunidades".

Com este objetivo, advoga, entre outras medidas, uma reforma do sistema financeiro que crie um sistema de regulação diferente do que foi introduzido nos EUA depois de 2008, que denuncia por ser "idêntico ao queijo suíço - cheio de buracos, de excepções e de isenções que não podem ser justificados por nenhum conjunto de princípios". Uma regulação que impeça os bancos de recorrer a práticas abusivas e a operações arriscadas de pura especulação, chegando mesmo a propor o encerramento dos bancos off-shore e dos seus parceiros on-shore e a regulação dos fluxos de capital transfronteiriços, sobretudo dos movimentos de capitais a longo prazo e especulativos. Defende também "uma agenda de crescimento baseada no investimento público". Por entender que o crescimento resultante do mero jogo das forças do mercado não beneficia todos automaticamente $\mathrm{e}$ necessariamente, como pensavam os clássicos (Adam Smith e Ricardo) e como persistem em defender os economistas fiéis do trickle-down effect. Por entender que os países com maiores êxitos neste domínio têm sido aqueles que "tomaram nas

94 Cfr. O Preço..., cit., 377. 
mãos o seu próprio destino e reconheceram o papel que o estado pode desempenhar no sentido do desenvolvimento, sem confiar na tese de um mercado auto-regulado que resolve todos os problemas". E por entender que a experiência mostra que os investimentos públicos estão, historicamente, associados aos períodos de aumentos mais elevados de produtividade. ${ }^{95}$

18. Só a atitude da "esquerda choramingas" (ou "esquerda de direita"), que "nunca quer questionar nada", permite compreender a facilidade com que, em março/2012, foi aprovado (como sempre, "à porta fechada", a pretexto da crise) o chamado Tratado Orçamental.

Este Tratado ignora todas as críticas feitas às deficiências estruturais da UEM (que a presente crise tornou visíveis a olho nu), persistindo em negar o que Paul Krugman considera "o fracasso de uma fantasia". ${ }^{96}$ Só esta atitude de "negação' explica que se insista no erro de impor as mesmas regras (saídas da cabeça de tecnocratas iluminados e muito sensíveis aos interesses do grande capital financeiro) a países com situações e com histórias completamente diferentes, ignorando que a política não pode reduzir-se à aplicação mecânica de regras iguais para todos.

Os seus mentores continuam a pensar que a crise do euro (a crise da 'Europa') não tem nada que ver com a crise do capitalismo que teve início em 2007/2008, imputando as culpas da 'crise' aos povos do sul, acusados de viver acima das suas posses. Só assim se compreende que toda a sua lógica assente na condenação dos 'pecadores' por 'pecados' que não cometeram, impondo-lhes programas de austeridade perpétuos que destroem as suas economias, põem em causa as regras

${ }^{95}$ Ver O Preço..., cit., 26, 211 e 357ss e El Malestar..., cit., 309.

96 Cfr. P. Krugman, "Quando..., cit. 
do estado de direito democrático e minam as bases da sua soberania.

Um dos dogmas do monetarismo neoliberal é o da morte da política económica (a morte da política, sem mais). Porque as leis naturais do mercado (a reinventada mão invisível) resolvem tudo sem erro possível, para além do justo e do injusto, e porque os agentes económicos privados dispõem da mesma informação do estado, o que lhes permite antecipar as medidas de política económica e os seus efeitos e agir como agentes económicos racionais, adotando comportamentos que anulam os efeitos das políticas públicas, tornando-as neutras em relação à economia, e por isso desnecessárias (é a teoria das expectativas racionais, a fina flor do monetarismo)..$^{97}$

Em conformidade com estes pontos de vista, o Pacto e as suas 'regras' impedem os estados em situação de recessão económica e de desemprego generalizado de adotar políticas ativas anti-cíclicas, apoiadas em investimentos públicos que promovam o investimento privado e a criação de riqueza e de emprego e em políticas sociais que estabilizem a procura interna das famílias e evitem, deste modo, a falência de muitas pequenas e médias empresas e o consequente aumento do desemprego. A razão está do lado do Primeiro-Ministro britânico quando afirmou que este tratado traduz o propósito de tornar ilegal o keynesianismo.

Creio, porém, que é necessário ir mais longe. Porque o que está em causa, verdadeiramente, é a ilegalização da democracia, num Tratado que transforma em normas jurídicas (que 'constitucionaliza') pontos de vista doutrinários em matéria de política económica. Com efeito, a regra de ouro das finanças sãs (que, até há poucos anos, todos os manuais ridicularizavam...), à semelhança de outras constantes dos Tratados

97 Sobre a teoria das expectativas racionais, ou o meu estudo O keynesianismo..., cit., 125 ss e 437 ss. 
estruturantes da UE (a regra da independência dos bancos centrais, os requisitos do PEC, etc.), são meras sínteses das opções políticas do grande capital financeiro, as opções que têm servido de base à política de globalização neoliberal, transformadas, como que por magia, em normas jurídicas, de nível 'constitucional'.

$\mathrm{Na}$ minha leitura, estas regras (normas-travão) são as regras do jogo impostas à economia real e aos cidadãos pelo setor dominante da classe dominante do capitalismo de casino e visam garantir que os eleitos para cargos políticos (nos parlamentos ou nos governos) não tenham a veleidade de pretender honrar o mandato popular que receberam dos seus eleitores, prosseguindo políticas que não respeitem as regras do jogo. A mensagem que se quer fazer passar para os cidadãos da 'Europa' é clara: podem eleger partidos de direita ou partidos de esquerda, mas aqueles que forem eleitos ficam impedidos de respeitar aquele mandato, amarrados que estão por estas regras decorrentes do figurino neoliberal. ${ }^{98}$

Um dos ministros do governo de François Hollande (Benoît Hamon) confessou, numa entrevista, a sua "impres-

98 A famosa Regra de Friedman é a ilustre antepassada de todas as regras de ouro consagradas nos Tratados da UE. Ela traduz a tese segundo a qual os países deveriam ser privados da capacidade de emitir moeda discricionariamente, segundo a análise política feita pelos órgãos competentes do poder político democrático, para prosseguir objetivos políticos definidos por estes mesmos órgãos. Esta capacidade de decisão política (discretion) deveria ser substituída por uma regra (desejavelmente de natureza constitucional), nos termos da qual o banco emissor só deveria emitir moeda nova em medida igual à da taxa de crescimento do produto, acrescida de uma margem de $2 \% / 3 \%$. Nunca ninguém levou a sério esta proposta de Milton Friedman. Em vida, ele teve o azar de ver as suas teorias submetidas à prova da realidade, e muitos autores concluíram que as suas teorias estavam erradas (alguns acusaram-no mesmo de viciar dados estatísticos). Depois de morto, talvez o professor de Chicago comente: a vingança serve-se fria... 
são de que uma política de esquerda ou de direita apenas doseia de forma diferente os mesmos ingredientes". É o preço a pagar por quem assumiu, com 'grande sentido de estado', a responsabilidade da gestão leal do capitalismo. Lembra a 'história' que se conta de Henry Ford dirigindo-se aos compradores dos seus automóveis: podem escolher qualquer cor, desde que seja a preta. ${ }^{99}$

Ignorando que a raiz dos problemas está, como se torna cada vez mais claro, na natureza e na estrutura desta Europa do capital, este Pacto Orçamental continua a obra dos tratados anteriores que conduziram à UE, prosseguindo o processo de substituição da política (e da prestação de contas que lhe é inerente em democracia) pela aplicação mecânica e cega de regras (verdadeiros dogmas indiscutíveis, como é próprio dos dogmas) plasmadas neste e nos demais Tratados estruturantes da UE, todos praticamente petrificados, imutáveis, aspirando à eternidade.

O processo de integração europeia tem sido, na leitura de Habermas, um processo de "expropriação das entidades soberanas democráticas por poderes executivos”. Os órgãos do poder político eleitos pelo voto democraticamente expresso dos cidadãos já hoje são pouco mais do que marionetas comandadas a partir de Bruxelas ou de Frankfurt (ou a partir de Berlim, via Bruxelas e Frankfurt): não podem decidir sobre a emissão de moeda; não podem desvalorizar a moeda; dependem dos "mercados" para se financiar (como uma qualquer pessoa ou empresa - uma verdadeira 'privatização’ dos estados-membros da zona euro); não podem fixar e controlar as taxas de juro; não podem optar por um determinado nível de inflação que possa ajudar o crescimento eco-

${ }^{99}$ Ver jornais de 9.4.2013. Afinal, agora no Governo, Benoît Hamon parece resignar-se a caucionar políticas que em 2011 considerava um obstáculo ao progresso (cfr. supra, p. 80), políticas que sacrificam o estado-providência para restabelecer o equilíbrio orçamental e agradar aos mercados... 
nómico; não podem decidir sobre o nível da despesa pública, sobre o montante do défice das contas públicas ou sobre a dimensão da dívida pública.

Este Tratado Orçamental dá mais um passo no sentido da acentuada diminuição da já reduzida democraticidade de funcionamento da UE. O 'governo' dos países mais fracos passa para as mãos de órgãos executivos constituídos por burocratas que escapam ao controlo democrático.

Como Habermas sublinha, este Tratado impõe "um modelo político que tem a marca alemã", um modelo nos termos do qual "os chefes de governo comprometeram-se a implementar nos seus respetivos países um catálogo de medidas a nível da política financeira, económica, social e salarial que, na realidade, seriam da competência dos Parlamentos nacionais (ou dos parceiros sociais)".

Por outro lado - continuo a acompanhar Habermas -, "o direito da Comissão a analisar atempadamente, portanto antes das decisões dos Parlamentos, os orçamentos dos estados-membros" "afeta competências fundamentais dos estados-membros e dos seus Parlamentos", o que traduz "a arrogância de criar um precedente eficaz". Para os cidadãos dos estados-membros (especialmente os mais fracos), fica a suspeita de "os seus governos nacionais serem apenas atores no palco europeu" e de os parlamentos nacionais "se limitarem a aprovar obedientemente (...) as decisões prévias tomadas noutro lugar".

Ainda segundo este Tratado, os países (os mais fracos, claro) ficam sujeitos, em caso de incumprimento das suas 'regras', a sanções automáticas, aplicadas pela 'eurocracia', sem necessidade de qualquer votação (atualmente, as sanções têm que ser aplicadas por voto da maioria qualificada do Conselho Europeu que represente pelo menos 2/3 dos estados-membros e $62 \%$ da população da UE). E ficam ainda sujeitos a 'penas' aplicadas diretamente pelo TJUE, passando por 
cima do poder judiciário de cada um dos países (que continuam a declarar-se países soberanos).

Com Habermas, entendo que estas são soluções que não podem deixar de "corroer qualquer credibilidade democrática". ${ }^{100}$ Creio não me enganar ao afirmar que, se vier a ser aplicado, este Tratado Orçamental será uma 'lei de funil', porque ninguém acredita que a Alemanha (ou a França, e mesmo a Itália, a Espanha e até a Polónia) submeta as suas políticas económicas a debate prévio e à coordenação com as de outros países, no quadro das instituições comunitárias, passando por cima dos parlamentos nacionais. E ninguém concebe que a Alemanha (e outros países da UE) sofram algum dia as consequências do referido mecanismo automático de correção. O Tribunal Constitucional alemão não vai deixar, certamente, que seja a Comissão Europeia a decidir sobre o orçamento da Alemanha: esta matéria é da competência do Parlamento alemão. De todo o modo, não é crível que os países mais fortes (os atrás referidos) aceitem submeter-se a esta indignidade. Os visados são, é claro, os 'bárbaros do sul'.

Mais uma vez por portas travessas, este Pacto visa, fundamentalmente, consagrar ('constitucionalizar') o neoliberalismo e as políticas de austeridade para todo o sempre, tornando o crescimento impossível para muitos países. Ora, sem desenvolvimento económico faltarão as receitas indispensáveis para o investimento no futuro (os investimentos estratégicos na educação, na saúde, na investigação científica, na segurança social, nos transportes públicos, na habitação social e em todos os serviços públicos associados à qualidade de vida e ao desenvolvimento sustentado). Estes direitos (constitucionalmente consagrados) transformar-se-iam em um luxo inacessível aos povos 'colonizados'. Países como Portugal (e

100 Cfr. J. Habermas, ob. cit., 165/166. 
os 'países do sul') sofreriam um brutal retrocesso civilizacional, vendo inviabilizada a sua capacidade de desenvolvimento autónomo. E sem desenvolvimento não há democracia e a paz fica ameaçada.

Como tudo o que de relevante vem acontecendo na UE desde Maastricht, este Pacto é "um modelo político de marca alemã", um produto imposto não por uma "Alemanha cooperante", mas pela Grande Alemanha, liberta da "consciência de uma herança histórico-moral comprometedora" que, após a derrota militar, política e ética da Alemanha nazi, ditou uma atitude de "moderação diplomática e disponibilidade para adotar também as perspetivas dos outros", mas por uma Alemanha ciosa de afirmar "uma clara pretensão de liderança" numa "Europa marcada pelos alemães". ${ }^{101}$

Agravando o adquirido anterior, ele perfila-se como um verdadeiro pacto colonial imposto pelos 'arianos' do norte aos 'bárbaros' do sul, incapazes de autogoverno, visão que, embora traduza uma certa realidade, não pode esconder a verdadeira essência do que está a passar-se: uma imposição do capital financeiro e dos estados e outras instâncias do poder político ao seu serviço - a ditadura do grande capital financeiro - à grande massa dos que, em todo o mundo, vivem do seu trabalho.

Trata-se de um pacto através do qual as elites políticas das 'metrópoles' e das 'colónias', continuando a “enterrar a cabeça na areia" (Habermas), se conluiam para impedir a participação dos cidadãos europeus no governo da 'cidade' e nas decisões sobre o seu destino, impondo aos povos dos países mais fracos, sem os consultar, a sua própria colonização e o seu próprio subdesenvolvimento. Creio ser correto considerá-lo nulo, porque não é razoável admitir que os povos, em nome dos quais se 'contrata', aceitassem ser colocados em situação 'colonial', condenados ao subdesenvolvimento e à pobreza.

101 Cfr. J. Habermas, ob. cit., 73 e 163-169. 
Está-se a construir um novo Leviathan, argumentando que os homens e os povos (ou alguns povos do 'sul') são incapazes de autogoverno. Daí a necessidade do Leviathan, para pôr ordem na casa, moderar os que gostam de viver acima das suas posses, governar o presente e garantir o futuro. Ao fim e ao cabo, é sempre o Leviathan 'justificado' com a invocação de que o homem é o lobo do homem. Com efeito, nas sociedades que assentam na existência de classes antagónicas e em que, no domínio das relações económicas, "o trabalhador [que só tem de seu a "sua força e habilidade de mãos"] é uma pessoa e o proprietário do capital, que o emprega, é outra pessoa", o Leviathan é sempre necessário para que a classe dominante (a classe exploradora) possa impor à(s) outra(s) classe(s) "os seus próprios termos" (continuando a citar Adam Smith), condição indispensável para preservar o seu estatuto de classe dominante. ${ }^{102}$

Ora o Leviathan dos nossos tempos (a ditadura do grande capital financeiro, enquadrada pela ideologia neoliberal) coloca acima de tudo as liberdades do capital (as "leis do mercado"). As 'regras' impostas pelo novo Leviathan equivalem, pois, à substituição da política pelo mercado, à negação da política (e da liberdade de decisão que ela pressupõe, com a correspetiva responsabilidade), à negação da cidadania e à morte da democracia. É este o papel do Pacto Orçamental.

19. Entre outras medidas, o Pacto Orçamental impõe um limite máximo de $0,5 \%$ do PIB para o défice das contas públicas, acrescentando a esta exigência a obrigação de os estados com dificuldades financeiras reduzirem a dívida a uma taxa média anual de $1 / 20$. Segundo os cálculos da Unidade Técnica de Apoio Orçamental, a meta de reduzir a dívida pública para valores próximos de $60 \%$ do PIB em vinte anos

102 Cfr. Riqueza das Nações, I, 176. 
só poderá ser alcançada se o PIB crescer a uma taxa de 4\% ao ano e as contas públicas apresentarem um saldo primário positivo de cerca de 3,5\%. Ninguém acredita que tal seja possível, uma vez que, depois deste período de dura austeridade, em 2013 o país continua a ver o PIB diminuir, o saldo primário permanece negativo e a dívida pública aumentou para 130,9\% do PIB (julho/2013).

As exigências do Pacto Orçamental configuram, pois, um garrote eficaz para pressionar estes estados a cortar drasticamente nas despesas sociais (educação, saúde, segurança social), com a consequente destruição do estado social, aumento da desigualdade e da pobreza, destruição do mínimo de coesão social e consequente destruição da comunidade social em que assenta a soberania.

Em países como Portugal, o objetivo do crescimento e do emprego exige reformas estruturais radicalmente diferentes das que decorrem do breviário neoliberal, reformas que passam pela alteração do estatuto esquizofrénico do BCE; pela flexibilização das regras 'estúpidas' e 'medievais' do PEC; pela alteração do estatuto do euro; pela utilização da capacidade de financiamento do BEI; pela ampliação do orçamento comunitário; pelo reforço e facilitação do acesso aos fundos estruturais da UE; pelo cumprimento das regras do jogo por parte dos países com saldos positivos das suas balanças de pagamentos; pelo combate ao dumping fiscal no seio da UE; pelo controlo pelo estado da poupança nacional e do seu destino; pela colocação da banca ao serviço da economia; pelo aumento dos salários e pela garantia dos direitos dos trabalhadores; pelo reforço do papel do estado em setores estratégicos da economia; pelo aumento do investimento do estado, nomeadamente em infraestruturas e nos setores da investigação científica, da educação e da formação profissional; pelo apoio às pequenas e médias empresas e às empresas exportadoras, às atividades da pesca e da agricultura; pelo apoio 
ao emprego dos jovens, para evitar que continue a hemorragia emigratória de jovens (sobretudo de jovens qualificados, cuja formação pagámos), ao ritmo de cem mil por ano (é o futuro a emigrar de Portugal).

Ora, como mostrou António Sérgio, a burguesia portuguesa foi sempre, historicamente, uma burguesia parasita, incapaz de realizar o papel de classe dinamizadora da acumulação do capital, que lhe coube nos países que passaram por revoluções burguesas a sério. No nosso país, a burguesia sempre viveu de rendas, as rendas fáceis de uma qualquer Índia, quer a Índia propriamente dita (que proporcionou a riqueza do comércio das especiarias), quer o Brasil (e o ouro que de lá veio, e os escravos africanos que para lá foram levados), quer as colónias africanas. Mais recentemente, as rendas resultantes dos fundos da CEE/UE (antes, da Europa já tinham vindo, aos milhões, as remessas dos emigrantes), as rendas da especulação bolsista e da especulação imobiliária, as rendas resultantes das posições monopolistas dos grupos económicos nos setores de bens não-transacionáveis (distribuição, energia, comunicações, obras públicas...), as rendas das parcerias público-privadas, as rendas da corrupção institucionalizada...

Nestas condições, qualquer estratégia de desenvolvimento só será viável se por detrás dela estiver um estado radicalmente diferente daquele que pretende o Tratado Orçamental, um estado dotado dos meios indispensáveis para promover as referidas reformas estruturais, um estado capaz de garantir a subordinação do poder económico-financeiro ao poder político democrático, como manda a Constituição.

20. Depois do debate suscitado, sobretudo na França, durante o período que antecedeu o referendo sobre a chamada constituição europeia e tendo em conta os resultados desastrosos das políticas neoliberais adotadas para combater a crise pela Comissão Europeia e pelo BCE, sob a batuta da 
Alemanha, seria de esperar que, desta vez, ao menos na França, os socialistas viessem dizer que o pacto orçamental devia ser pura e simplesmente posto de lado, porque a 'regra de ouro' e outras 'regras' que ele contém arrastam consigo um entrave estrutural ao desenvolvimento da Europa e condenam os países mais débeis ao 'subdesenvolvimento' e a um verdadeiro estatuto colonial.

Esta expectativa foi alimentada pelo facto de o candidato François Hollande ter prometido durante a campanha eleitoral para a Presidência da República que tal Tratado não seria aprovado pela França se as políticas de crescimento e de emprego não passassem a ser a primeira preocupação da UE. A verdade é que, uma vez eleito, François Hollande tornou-se, como sublinha Perry Anderson, "o intendente francês" do "sistema neoliberal europeu", pelo que esperar dele "um pouco mais de independência económica ou estratégica já será uma vitória da esperança sobre a experiência". ${ }^{103}$ A experiência, porém, parece estar a confirmar-se, à custa da esperança. Como é sabido, o Presidente François Hollande comportou-se como vêm fazendo há anos os políticos e os partidos burgueses (que se auto-intitulam do "arco da governação"): fez exatamente o contrário do que tinha prometido ao povo francês que o elegeu, 'obrigando' os deputados socialistas a aprovar o referido tratado na Assembleia Nacional.

Mais uma vez, a social-democracia europeia não quis aprender nada com a história e aprovou mais este 'tratado' em plena paz de consciência, como disse o mais alto responsável do PS português no momento da ratificação do 'tratado' na Assembleia da República, lamentando apenas que não se tivesse aprovado também uma adenda (afinal, não era muita coisa: só uma adenda...) sobre as políticas de crescimento e de emprego.

103 Cfr. P. Anderson, ob. cit. 
Em 28.6.2012, por proposta de Hollande, o Conselho Europeu aprovou o Pacto para o Crescimento e Emprego, encerrando com 'chave falsa' o espetáculo encenado para fazer de contas que a UE passava a preocupar-se com o crescimento e o emprego, apesar de continuar a impor programas de austeridade fortemente recessivos e de não desistir de levar por diante o "golpe de estado europeu" configurado no Tratado Orçamental. ${ }^{104}$

Este Pacto para o Crescimento e Emprego não passa de uma merkolandía, uma 'mercadoria' inventada pela dupla Merkel e Hollande para calar a (má) consciência de Hollande e para 'legitimar' o dito Tratado Orçamental imposto pela chanceler alemã. Assim sendo, é claro que ele não vai ativar nenhuma política nova destinada a promover o crescimento e o emprego. Ao aprovar este novo Pacto, o Conselho Europeu enganou os povos da Europa e criou uma situação ridícula, que não abona a seriedade intelectual e política das instituições comunitárias e das políticas comunitárias.

$\mathrm{Na}$ verdade, com os dois Tratados em vigor simultaneamente, tudo se passa como se a UE e os estados-membros fizessem o seu caminho pedalando e travando ao mesmo tempo. Encerrado o tempo da propaganda, com a França e a Alemanha a proclamarem divergências sérias quanto ao rumo da política comunitária em matéria de crescimento e de emprego, o que tal 'solução' significa é o entendimento estratégico entre os socialistas de Hollande e os conservadores de Merkel no sentido de prosseguir as políticas de austeridade ao serviço das finanças sãs, com o argumento de que elas são indispensáveis para sanear a economia e de que (sempre o velho slogan thatcheriano) não há alternativa para elas.

Bem vistas as coisas, a aprovação do Pacto para o Crescimento e Emprego significa que os governos da França e da

104 R.-M. JENNAR, ob. cit. 
Alemanha (e todos os que lhes seguiram os passos) estão irmanados na sua fé neoliberal, que lhes dá força para manter em vigor o Tratado Orçamental aprovado em março/2012, que é um pacto contra o crescimento e contra o emprego e que, por detrás das propostas 'técnicas' nele contidas, encerra uma visão totalitária, que suprime a soberania e a igualdade entre os estados membros da UE (que os Tratados continuam a consagrar) e que aponta para a colonização dos pequenos países pelos grandes, arrastando consigo ameaças sérias à democracia (e à paz) na Europa.

As posições doutrinais e a prática política dos governos nacionais e das instituições comunitárias justificam inteiramente as preocupações do antigo Presidente socialista do governo de Espanha, Felipe González, que, no início deste ano de 2013, reconhecia os perigos inerentes à crise da democracia representativa: "Os cidadãos pensam, com razão, que os governantes obedecem a interesses diferentes, impostos por poderes estranhos e superiores, a que chamamos mercados financeiros e/ou Europa. É perigoso, pois tem algo de verdade indiscutível". ${ }^{105}$

21. Outra mistificação é a chamada União Bancária, mais uma operação destinada a tentar que os povos acreditem que

105 Entrevista ao Expresso, 5.1.2013. Ninguém melhor para confirmar este diagnóstico de Felipe González do que um antigo ministro da economia num Governo do PSOE, ao fazer esta confissão, num livro publicado em 1996: "a redução do desemprego, longe de ser uma estratégia de que todos sairiam beneficiados, é uma decisão que, se fosse levada à prática, poderia acarretar prejuízos a muitos grupos de interesses e a alguns grupos de opinião pública" (citação colhida em V. NAVArro, J. López e A. Espinosa, ob. cit., 83/84). Quer dizer: as políticas ativas de combate ao desemprego e de promoção do emprego não são levadas a sério porque o desemprego interessa a muitos grupos de interesses, os interesses ligados ao grande capital, que, enfraquecendo os trabalhadores e as suas organizações, podem reforçar as condições da sua exploração. 
a 'Europa' está a procurar resolver os problemas criados pelo capital financeiro.

Segundo os Tratados, o BCE não tem grandes competências em matéria de supervisão, estando limitado à possibilidade de fazer recomendações às autoridades nacionais no que toca à supervisão prudencial das instituições de crédito e à estabilidade do sistema financeiro.

E a crise deixou a claro que, à escala nacional, a supervisão (a cargo das entidades reguladoras) foi um falhanço completo: os supervisores deixaram o campo livre à banca, que cometeu toda a sorte de irresponsabilidades, de ilegalidades e de crimes.

Em estreita ligação com o projeto que se concretizou na aprovação do Pacto Orçamental, a Alemanha fez vingar a ideia de criar uma União Bancária, projeto que está em marcha desde a aprovação (24.11.2010) de um conjunto de cinco Regulamentos e uma Diretiva que visaram reformar o sistema financeiro da UE (em especial no tocante à supervisão macroprudencial), criando o Sistema Europeu de Supervisão Financeira, o Comité Europeu do Risco Sistémico e uma Autoridade Europeia de Supervisão (Autoridade Bancária Europeia, Autoridade Europeia dos Seguros e Pensões Complementares de Reforma, Autoridade Europeia dos Valores Mobiliários e dos Mercados), confiando ao BCE atribuições específicas no que se refere ao funcionamento do Comité Europeu do Risco Sistémico. ${ }^{106}$

O Regulamento que cria o Sistema Europeu de Supervisão Financeira - Sistema que visa essencialmente a gestão do risco sistémico ${ }^{107}$-, reconhece que "os modelos de supervisão numa base nacional não acompanharam a globalização financeira e a qualidade da integração e interligação entre

106 Para maiores desenvolvimentos sobre este "pacote legislativo", ver J. M. Quelhas, "Sobre a criação..., cit. e "Dos objetivos..., cit.

107 Regulamento n. ${ }^{\circ}$ 1092/2010 do Parlamento Europeu e do Conselho, de 24.11.2010 (JO, L 331, de 15.12.2010). 
mercados financeiros europeus". E admite que, dada a natureza sistémica do risco e das crises $^{108}$, decorrente da integração dos mercados financeiros à escala mundial (o mercado mundial único de capitais em que atuam os grandes operadores financeiros de todo o mundo), é aconselhável uma coordenação das ações preventivas e reativas das entidades supervisoras, cometendo ao Comité Europeu do Risco Sistémico a competência para assegurar a coordenação das suas ações com outras instâncias internacionais (FMI, Conselho de Estabilidade Financeira, Banco de Pagamentos Internacionais, G20, etc.).

Em documentos vários a Comissão Europeia tem salientado a importância que atribui à coordenação entre os estados-membros em matéria de regulação e de supervisão, chamando a atenção para a necessidade de introduzir medidas que visem impedir crises futuras (espreita também aqui a tese segundo a qual, nesta crise, o que falhou foi a regulação e a supervisão, nada mais...).

A Comissão revela especial preocupação com a supervisão das instituições financeiras transfronteiriças e com a consolidação de "um mercado de serviços financeiros estável e único para toda a União", objetivos que considera incompatíveis com a diversidade de regras nacionais de supervisão e com a deficiente troca de informações entre as várias autoridades nacionais, exigindo a integração de todas elas numa rede reforçada da União.

Esta ideia de evitar a fragmentação do mercado financeiro europeu e de garantir o êxito do mercado interno único é que está na base da criação (novembro/2010) do Comité Conjunto das Autoridades Europeias de Supervisão. Na Comunicação sobre o Roteiro para uma União Bancária, a Comissão dá mais um passo em frente no sentido da federalização, ao sublinhar que não basta, a seu ver, a coordenação entre as várias auto-

${ }^{108}$ Ver J. M. Quelhas, “Dos objetivos..., cit., 285. 
ridades de supervisão, sendo "necessário tomar decisões em comum", para "travar o risco crescente de fragmentação dos mercados bancários da UE, que mina significativamente o mercado de serviços financeiros e prejudica a transmissão efetiva da política monetária para a economia real".

O Conselho Europeu de junho/2012 encarregou a Comissão de apresentar propostas concretas sobre estas matérias, e o Conselho Europeu de dezembro/2012 aprovou, finalmente, a tão falada União Bancária.

Tentando uma síntese, destacarei três pontos:

1) centralização no BCE da supervisão dos bancos que operam nos estados da zona euro, apesar de existir, desde 2010, uma Autoridade Bancária Europeia com a capacidade de exercer a supervisão sobre os bancos que operam nos 27 estados-membros da UE;

2) criação de um dispositivo comum para prevenir e resolver as falências bancárias (competência que sairá também do quadro nacional dos países da zona euro);

3) criação de um fundo europeu de garantia de depósitos até cem mil euros (unificando, aparentemente, os múltiplos regimes de garantia de depósitos em vigor nos países da UE).

Como já se sabia, o RU ficou de fora, porque estas soluções confinam-se aos países da Eurozona. Fica à mostra uma primeira debilidade da 'solução' encontrada, porque cerca de $40 \%$ das operações financeiras em euros concretizam-se na praça londrina. ${ }^{109}$

109 Este caminho 'federador' afasta cada vez mais o RU não só da UEM mas da própria UE, no seio da qual, de resto, já tem um regime de excepção, resultante de um batalhão de cláusulas específicas, que o coloca com um pé fora e um pé dentro da UE. Há quem entenda que o RU não faz falta à União Europeia. É verdade que os dirigentes britânicos se 
Por outro lado, a Sr. ${ }^{a}$ Merkel conseguiu fazer aprovar a ideia de submeter à supervisão do BCE apenas os bancos mais importantes (uns 200 dos cerca de 6.000 que operam no espaço da Eurozona), uma 'engenharia' que permitiu deixar de fora os bancos dos estados federados alemães, que teriam dificuldade em passar no exame. Parecem as fronteiras do mapa cor de rosa, traçadas a regra e esquadro para proteger os interesses do império...

Acresce que esta União Bancária implica mais perda de soberania por parte dos estados-membros da zona euro, privados agora do poder de supervisão do setor bancário. E implica, por outro lado, o reforço dos poderes federais do BCE, que é uma instituição não eleita, que não pode sequer coordenar as suas decisões no âmbito da política monetária com as políticas da UE ou dos estados-membros e que não responde politicamente pelos seus atos.

Num momento em que tanto se fala (e não só em Portugal) da necessidade de criar bancos (ou agências) de fomento de capitais públicos que assegurem meios de financiamento adequados à re-industrialização e à promoção de um modelo de crescimento equilibrado e sustentado, coloca-se a questão de saber se este mecanismo único (federal) de supervisão será compatível com a atuação destas novas instituições segundo critérios 'políticos', não necessariamente coincidentes com os critérios puramente financeiros impostos pela 'filosofia' orientadora do BCE.

comportam muitas vezes mais como servidores dos interesses americanos junto da UE do que como membros solidários da UE. Mas também é verdade que a história da Europa não se concebe sem as ilhas britânicas e não é fácil imaginar o futuro da Europa sem elas e as suas gentes. E muito menos contra elas.

Mas levanta-se aqui, segundo creio, um outro problema. O tratado que cria a União Bancária vem alterar as competências estatutárias do BCE. Ora, constando os Estatutos do BCE do TUE, como pode este ser alterado sem o voto unânime dos estados-membros da UE? 
A criação deste mecanismo federal de supervisão representa mais um passo em frente no sentido do federalismo ao serviço dos mais fortes, sem qualquer garantia de que a supervisão efetuada pelo BCE seja de natureza diferente da efetuada até agora: ela será, certamente, uma supervisão amiga da banca e respeitadora dos dogmas neoliberais de que o BCE é um dos mais firmes guardiões.

À luz do que fica dito, não admira, por isso, que a União Bancária tenha sido saudada pela fina flor dos banqueiros europeus, que, aliás, dominaram as comissões encarregadas de preparar os dossiês (a começar pelo chamado Grupo Larosière, apelido de um funcionário de topo do BNPParibas). ${ }^{110}$

Os que estão sempre de acordo com tudo o que vem de Bruxelas (ou de Berlim) não se cansam de proclamar que a união bancária é 'a solução' para desligar os estados das dívidas da banca, de modo a que não sejam os contribuintes a tapar os buracos dos jogos de casino. Para isso está previsto o dispositivo comum para prevenir e resolver as falências bancárias...

É claro que é importante garantir que os estados (os trabalhadores, que são os grandes pagadores de impostos) não

${ }^{110}$ Invocando os objetivos de dificultar a ocorrência de novas crises financeiras como a que varreu o mundo em finais de 2007, a partir dos EUA, e de assegurar que a banca financie a economia real (um modo 'delicado' de dizer: assegurar que a banca não se dedique a práticas especulativas irresponsáveis e muitas vezes criminosas), a UE vem adotando medidas tímidas de regulação da atividade bancária, no âmbito de aplicação das decisões do Comité de Basileia (nomeadamente as regras de Basileia III). Trata-se do reforço dos capitais próprios dos bancos, da reforma dos chamados rácios de alavancagem, do reforço dos mecanismos de garantia dos depósitos, da moderação dos prémios a atribuir aos administradores da banca (para não os estimular a correr riscos excessivos). São medidas de fraco alcance (que ficaram aquém do previsto), mas o aparelho de Bruxelas acredita (ou diz que acredita...) que, se os EUA avançarem no mesmo sentido, ficará garantida a estabilidade do sistema financeiro... Ver o artigo do Comissário Europeu Michel Barnier, cit. 
sejam responsáveis pelas dívidas da banca. Mas este objetivo não se conseguirá, a meu ver, através da União Bancária. É necessário mudar de políticas, abandonar o novo dogma de que os bancos não podem falir (sobretudo os que são too big to fail, do mesmo modo que os seus administradores são too big to jail), é necessário subordinar a banca (o sistema financeiro) ao poder político democrático, é necessário pôr termo às liberdades do capital financeiro, que estão a aniquilar a liberdade dos povos e a soberania dos estados.

Talvez mais importante é garantir que os estados não continuem a depender dos 'mercados' para financiar as suas políticas e que as dívidas soberanas (os estados) não continuem a ser pasto da sanha especulativa desses mesmos "mercados' (=sistema financeiro="sida da economia mundial"). Mas disso não se ocupa a União Bancária, porque, para tanto, é indispensável pôr cobro à liberdade absoluta de circulação de capitais e à independência dos bancos centrais, modificando radicalmente a UEM e os estatutos do BCE.

Argumentam também que a União Bancária é necessária para que o euro continue a ser uma moeda forte, garantindo que ela vem pôr termo à fragmentação financeira atual, impondo uma entidade única de supervisão da banca, anunciando que, deste modo, se ultrapassará a situação de desigualdade em que hoje se encontram as empresas de diferentes países da zona euro no que se refere às condições de acesso ao crédito e às taxas de juro a pagar. As empresas portuguesas e as empresas alemãs ficarão em pé de igualdade!

Quer-se fazer passar a ideia de que a União Bancária, qual varinha mágica, nos livrará do 'inferno’ atual, governado pelas 'leis' do grande capital financeiro, e nos oferecerá o 'paraíso', pelo menos o paraíso do crédito... É pura matéria de fé, que só pode salvar os que acreditam nos dogmas da ideologia dominante.

Fará sentido acreditar que a União Bancária vai proporcionar crédito nas mesmas condições e aos mesmos custos 
a todas as empresas dos países da Eurozona, sem confiar ao estado a propriedade e a gestão das instituições financeiras? A UE ainda nem sequer conseguiu (nem está preocupada com isso!) que os seus estados-membros (estados soberanos e iguais, segundo os Tratados) tenham acesso ao crédito nas mesmas condições. A UE permite que funcionem no seu seio importantes paraísos fiscais para acolher os ganhos do crime sistémico e proteger os seus protagonistas (instituições financeiras, gente rica, empresários de sucesso, políticos bem comportados). A UE promove sistematicamente a concorrência fiscal entre os estados-membros (mesmo dentro da euro-zona, constituída por estados que têm a mesma moeda!), pondo de lado qualquer ideia de harmonização fiscal. A UE não é capaz de alimentar um orçamento comunitário digno deste nome. A UE está longe de caminhar, a sério, para a emissão de dívida comunitária. A UE não quer um banco central europeu ao serviço dos estados e dos povos. A própria UE e os 'estados dominantes' dentro dela impõem condições draconianas e cobram taxas de juro agiotas aos estados-membros carecidos de ajuda: a Alemanha financia-se a taxas de juro reais abaixo de $1 \%$ e emprestou dinheiro a Portugal (para nos ajudar, claro), no âmbito do Memorando de Entendimento, a taxas de juro de $5,1 \%$.

No quadro da União Bancária anuncia-se um fundo europeu de garantia de depósitos até cem mil euros. Dizem-nos que é uma medida para gerar confiança junto dos depositantes, que recuperarão o seu dinheiro, mesmo em caso de falência dos bancos. Mas as notícias que têm vindo na comunicação social especializada indicam que está muito longe de se concretizar a hipótese de criação de uma entidade única e supranacional (à escala da zona euro) que desempenhe esta função de garantir os depósitos bancários.

Por outro lado, a 'história' trágico-cómica do plano de assistência a Chipre veio deixar claro que tal fundo é só para 
depositante ver (os ricos a sério protegem o seu dinheiro nos paraísos fiscais...) e que a União Bancária é mais um expediente para enganar tolos. O confisco de parte significativa dos depósitos bancários só não avançou porque o clamor suscitado por tal medida foi enorme (até os bancos se devem ter assustado...). O que fica desta 'história', porém, é a certeza de que, ao mesmo tempo que se prossegue com a União Bancária para criar um clima de confiança à volta do sistema bancário e do comportamento da banca, mantém-se o confisco de uma parcela dos depósitos superiores a cem mil euros e proclama-se que esta 'solução' poderá ser aplicada em outros países 'intervencionados'. Em vez de serem os acionistas dos bancos a suportar os prejuízos, são os depositantes os sacrificados (com o argumento pio de que assim se poupam os contribuintes...). Admitido o princípio do confisco, o montante a partir do qual ele é praticável dependerá das circunstâncias... Nada melhor para criar confiança... Nada melhor para estimular a fuga de capitais, a menos que se generalize o sistema de controlo dos movimentos de capitais, como se fez em Chipre. Não seria mau que os países recuperassem essa capacidade, mas isso poria em causa o euro... (que foi posto em causa em Chipre: os euros do Chipre não são euros como os outros, porque não podem sair do país..., o que significa que, para este efeito, Chipre já 'saiu' do euro...). Este é o retrato da União Bancária, tal como ela se me apresenta. Estarei a ver mal?

A ideia de União Bancária parte do pressuposto de que existe na UE (ou na zona euro) um mercado bancário interno único, pressuposto que a realidade não confirma. A este respeito, como a muitos outros, a situação atual na 'Europa' está longe de corresponder a um espaço económico onde impere a famosa concorrência livre e não falseada. Estamos muito mais próximos de um espaço no seio do qual os países mais fortes (os do 'norte') impõem aos mais fracos (os do 'sul) um 
verdadeiro regime de pacto colonial. Só assim se compreende que o estado português e as empresas portuguesas tenham de se financiar junto dos "mercados" a taxas de juro muito superiores às exigidas pelos "mercados" à Alemanha e às empresas alemãs. Não há mercado bancário interno único, ou então é um mercado monopolista, com poder de mercado (e poder político) bastante para aplicar preços diferentes a clientes que se propõem adquirir o mesmo produto. Os preços (taxas de juro) mais baixos são oferecidos aos clientes mais fortes, que não são, necessariamente, os melhores clientes; os clientes mais fracos são obrigados a pagar preços (taxas de juro) mais elevados, ainda que possam ser melhores clientes (há, certamente, empresas portuguesas que são melhores do que algumas empresas alemãs). Não há concorrência, há domínio.

Em suma: a criação da União Bancária significa mais um passo no sentido da consolidação da 'Europa' como uma estrutura federal distorcida (uma espécie de federalismo de funil...), funcionando cada vez mais à margem do jogo democrático. Com efeito, o caminho da federalização encapotada está a fazer-se, mais uma vez, sem que os povos da Europa fossem ouvidos sobre estes 'avanços', certamente com o argumento (já utilizado em outras circunstâncias pela inteligentzia europeísta, herdeira intelectual da velha nobreza feudal) de que os povos são ignorantes e não têm discernimento para opinar sobre tão complexas questões técnicas. Cumpre-se a tradição de um processo que tem decorrido sempre "à porta fechada”, sem a participação dos povos da Europa e, portanto, contra os povos da Europa. É bom de ver que uma 'Europa' assim não pode ter grande futuro.

Uma coisa é certa: as reformas estruturais apregoadas pelas centrais ideológicas e pelos poderes ao serviço do capital financeiro são apenas as que se destinam a privar os trabalhadores do direito de ter direitos, e esta 'reforma' do sistema bancário não é a reforma estrutural que as circunstâncias há 
muito impõem. Na verdade, nada se fez para regressar ao regime (introduzido nos EUA em 1933 pela Lei Glass-Steagall) de separação absoluta entre bancos comerciais (que aceitam depósitos com base nos quais concedem crédito a curto e a médio prazo às famílias e às empresas) e bancos de investimento (que se especializam na gestão de patrimónios, nomeadamente através de aplicações financeiras de alto risco). O sagrado princípio da banca universal saiu intocado desta 'reforma', o que significa que os grandes bancos podem continuar a especular livremente. ${ }^{111}$

E, no entanto, toda a gente sabe que é esta liberdade do capital que está na base das crises bancárias que se foram verificando nas últimas três décadas e, muito claramente, na base desta crise que rebentou nos EUA em 2007/2008. O setor banca de investimento dos grandes bancos joga forte na especulação e acaba por se encharcar de ativos tóxicos. Os prejuízos dos jogos de casino sugam os recursos do setor banca comercial (os capitais próprios e os depósitos dos clientes), e, como estes recursos não chegam, os estados são chamados a salvar os bancos too big to fail, endividando-se para financiar estas operações de salvamento e fazendo cair sobre os trabalhadores-contribuintes os custos de todas estas operações, ao mesmo tempo que a banca comercial fica sem dinheiro para financiar as atividades produtivas, agravando assim o clima recessivo resultante das políticas contracionistas adotadas pelos estados-salvadores-do-grande-capital-financeiro-especulador, com o (falso) fundamento de que é necessário combater o despesismo e cortar cerce o vício dos povos de viver acima das suas posses. ${ }^{112}$

111 Esta foi uma das promessas de François Hollande. Mas a promessa pariu um rato.Ver D. PliHON, "Uma reforma..., cit. 13.

112 Nos primeiros dias de fevereiro/2013, os media anunciaram que o governo alemão vai propor ao parlamento legislação que puna mais severamente (incluindo com pena de prisão) os banqueiros que não cum- 
A reforma estrutural mínima do sistema financeiro na Europa tem de começar pela alteração profunda do estatuto 'esquizofrénico' do BCE, para que ele assuma as responsabilidades de um verdadeiro banco central. E não pode deixar de pôr fim à liberdade absoluta de circulação de capitais, ao princípio da banca universal e à liberdade de criação de produtos financeiros derivados, que não são mais do que fichas para jogos de casino. E tem de permitir aos estados nacionais o controlo dos movimentos internacionais de capitais. Sem isto, o mundo continua entregue aos especuladores (aos tipos que são a sida da economia mundial).

22. Estas são questões que vêm sendo negociadas em grande segredo, entre os EUA e a UE, desde julho/2013, com vista a um futuro Acordo de Parceria Transatlântica (APT), que se espera possa estar concluído dentro de dois anos. ${ }^{113}$

prirem as boas práticas de gestão bancária e que, em certas condições, obrigue os bancos a separar as atividades próprias da banca de investimento das atividades correntes da banca comercial, entregando aquelas a uma sociedade comercial criada para o efeito.

113 O Big Business está a tentar de novo o que já foi tentado na década de 1990, através do famoso AMI (Acordo Multilateral sobre o Investimento), negociado entre 1995 e 1997 pelos estados-membros da OCDE. Foram negociações ultra-secretas, para que os povos não conhecessem o que se estava a urdir nas suas costas. Mas o texto foi conhecido antes da sua aprovação final. E os protestos foram tantos, em várias partes do mundo, que o AMI foi posto de parte. Está agora a ser ressuscitado, através das negociações acima referidas, também ultra-secretas, ativadas por pressão e sob a batuta do Trans-Atlantic Business Council, um grupo empresarial de lobbying criado em 1995 com o patrocínio da Comissão Europeia e da Administração americana, e que funciona como um fórum permanente de coordenação de ações de oposição às políticas públicas que podem limitar as liberdades do grande capital no âmbito do comércio internacional e de promoção da desregulação total em todos os setores, para facilitar o livre comércio internacional. Sobre as negociações com vista ao APT e tudo o que elas envolvem, ver o interessante artigo 
Nestas negociações estão envolvidas múltiplas questões relacionadas com a desregulamentação de vários setores de atividade, com o propósito de facilitar o desenvolvimento do livre comércio, em nome da ideia de que a plena liberdade do comércio internacional é a estrada real para o crescimento económico e para o progresso de todo o mundo. É a filosofia inspiradora da OMC levada ao extremo, apesar da contestação teórica a esta tese, que a realidade desmente todos os dias.

As negociações em causa aceleraram-se depois de concluídas, em outubro/2013, as conversações para um Acordo de Comércio Livre entre o Canadá e a União Europeia (inspirado pela mesma filosofia), conversações cujo êxito animou as grandes empresas multinacionais e o grande capital financeiro a aumentar a pressão sobre a Administração americana e sobre a Comissão Europeia no sentido de aprovar o referido APT.

No que aqui nos interessa de modo especial, direi que o grande capital financeiro está a fazer pressão no sentido de 'matar' os projetos de levar por diante qualquer tipo de imposto sobre as transações financeiras. No quadro da UE, apesar da discussão que sobre esta matéria se tem desenvolvido nas instituições comunitárias e dos documentos já aprovados a este respeito $^{114}$, parece que a vida não está fácil para aquele imposto, uma vez que a Comissão Europeia já se manifestou no sentido de reconhecer que ele pode não respeitar as regras da OMC. No mesmo sentido aponta a posição do FMI, que discorda de qualquer tipo de controlo sobre os movimentos de capitais.

Do lado europeu, a Associação dos Bancos Alemães (em que pontifica o Deutsche Bank) vem fazendo pressão para que

de Lori Wallach (Diretora da Public Citizen's Global Trade Watch, em Washington), sobre este " tufão que ameaça os europeus", cit.

${ }^{114}$ Ver o meu livro A Crise..., cit., 182-187. 
sejam postas de parte as envergonhadas reformas do sistema financeiro introduzidas nos EUA depois de 2008.

De um e de outro lado do Atlântico, os grandes bancos e as grandes companhias de seguros estão satisfeitos com o capitalismo sem falências inventado para os salvar da bancarrota, que é também o capitalismo sem risco e o capitalismo do crime sistémico ("too big to fail", "too big do jail"), e rejeitam qualquer tipo de regulação das 'indústrias' da banca e dos seguros, nomeadamente no que se refere aos investimentos de alto risco. Não se trata apenas de se oporem à sua proibição pela banca comercial. Eles opõem-se igualmente ao controlo por parte do estado da natureza e do volume desses 'investimentos' ou da origem dos 'produtos financeiros' colocados no mercado. O grande capital financeiro quer continuar a jogar no casino, impunemente, e defende com unhas e dentes o capitalismo de casino.

Se o APT vier a ser aprovado e levado à prática, os estados nele envolvidos que não cumprirem as regras impostas pelo 'código' ultraliberal que ele representa ficarão sob a mira de 3300 empresas europeias implantadas nos EUA (com 24 mil filiais) e de 14.400 empresas americanas a operar na Europa (50.800 filiais). Todas elas poderão demandar, elas próprias, os estados infratores junto de tribunais arbitrais especiais (à margem da organização judiciária dos estados, e de cujas decisões não há recurso), para exigir o pagamento de pesadas reparações financeiras, alegando que as políticas desses estados restringem o seu dinamismo comercial, quebram as suas expetativas, desvalorizam os seus ativos ou impedem a realização de lucros esperados. ${ }^{115}$

115 Segundo dados da CNUCED, o número de ações movidas junto destes tribunais arbitrais especiais decuplicou desde 2000 e sofreu um forte incremento nos últimos dois anos.

Alguns exemplos (colhidos em L. WaLlach, ob. cit.) de ações intentadas por empresas multinacionais contra estados soberanos, ao abrigo de 
O Big Business dos EUA e da UE ficará em condições de impor a todos os países que pretendam manter relações com estes dois grandes blocos comerciais o ‘código' ultraliberal que já está em vias de aprovação por doze países da zona do Pacífico, no âmbito do Trans-Pacific Partnership (TPP). O grande capital reforçará, deste modo, os instrumentos de domínio no seu 'império' mundial, transformando o mundo num grande paraíso judiciário (sem lei e sem tribunais verdadeiros), em que tudo lhe é permitido.

É particularmente importante o que está em causa nas negociações em curso com vista à aprovação do mencionado APT. Os estados abrangidos por este Acordo perderão grande parte da sua soberania, sacrificada ao 'paraíso' prometido pelo livre comércio internacional, em nome do qual se permite às grandes empresas multinacionais oporem-se, junto dos 'seus' tribunais, às políticas públicas relativas ao mercado financeiro, à política fiscal, à legislação laboral, à política de salários, à política de defesa do ambiente, de controlo da quali-

acordos já em vigor, inspirados pelos princípios do livre comércio. Empresas europeias acionaram o estado egípcio por ter aumentado o salário mínimo; uma empresa americana acionou o estado do Perú por ter limitado as emissões tóxicas no país; tabaqueiras americanas demandaram em tribunais especiais a Austrália e o Canadá porque agravaram a legislação antitabaco; uma empresa farmacêutica americana acionou o Canadá por ter estabelecido um sistema de proteção de patentes que não lhe agradou. Os montantes das indemnizações atribuídas às multinacionais atingem somas astronómicas: o Equador foi condenado recentemente a pagar dois mil milhões de euros a uma petrolífera. Mesmo quando os estados demandados ganham as ações, são obrigados a pagar as custas do processo (em média, oito milhões de dólares por processo). Para evitar o risco de um esbulho deste tipo em ação que estava iminente, o estado canadiano apressou-se a revogar legislação que proibia um aditivo tóxico usado pela indústria petrolífera. 
dade dos alimentos, à política referente aos serviços públicos (saúde, energia, educação, água, transportes, etc.). ${ }^{116}$

${ }^{116}$ Vale a pena referir alguns dos temas já em debate a este respeito.

Sabe-se que $80 \%$ dos consumidores americanos apoiam a obrigatoriedade de identificar nas embalagens os produtos que contêm organismos geneticamente modificados (OGM), medida que vários estados federados (metade) tencionam introduzir. Mas os 'industriais' dos setores interessados (com a Monsanto à frente) opõem-se ferozmente ao direito dos consumidores a ser informados daquilo que compram e consomem. É claro que a Monsanto lidera também o lobby que pressiona no sentido de que o futuro APT deite por terra a legislação europeia que impede (ou dificulta) a importação de produtos que contêm OGM.

As empresas de aviação americanas pressionam no sentido de ser abolido o sistema europeu de quotas de emissões, que obriga as companhias aéreas a pagar a poluição que causam pela emissão de carbono. Mesmo sem o APT aprovado, a Comissão Europeia suspendeu a aplicação da legislação contestada pelas empresas americanas.

A carne (de vaca e de porco) produzida nos EUA contém um produto químico destinado a aumentar a percentagem de carne magra. Este produto é nocivo para saúde dos animais e dos consumidores, razão por que foi proibido em 160 países, entre os quais todos os da UE, Rússia e China. Os produtores americanos pressionam no sentido de o APT acabar de vez com esta limitação ao livre comércio.

O poderoso grupo das empresas americanas ligadas ao comércio digital vem exercendo enorme pressão no sentido de que o APT derrube a resistência europeia à livre circulação dos fluxos de dados pessoais. Empresas que fornecem serviços à National Security Agency (o serviço secreto americano que Edward Snowden denunciou ao mundo por andar a espiar mensagens de email e conversas telefónicas de milhões de pessoas, incluindo altos dirigentes políticos europeus) insistem em que o APT não permita que a proteção da segurança e da vida privadas possa servir de pretexto para colocar entraves ao comércio.

Não consigo deixar de pensar que se trata de verdadeiros crimes contra a humanidade. De todo o modo, a civilização está em causa, e ela não pode ser objeto de negócio acertado em segredo por aqueles que atentam contra os valores da civilização que construímos, com a cumplicidade de alguns dirigentes políticos e de alguns estados e de alguns organismos internacionais. 
Afinal, G. W. Bush tinha razão ao falar do império do mal. O império do mal é este 'império' do capitalismo do crime sistémico, é este 'império' que a "grande democracia americana" e a democrática UE estão agora a montar, em ambiente de grande segredo conspirativo, à revelia dos povos dos EUA e do continente europeu, e, afinal, de todos os povos do mundo, igualmente 'súbditos' deste império do mal.

23. Parece hoje indiscutível que foi um erro a nossa adesão ao euro-moeda-única, ainda por cima a este euro alemão, concebido e concretizado ao serviço da estratégia imperial da Alemanha. O Relatório Anual do Banco de Portugal (2012) é claro: nos 13 anos posteriores à nossa adesão ao euro o crescimento acumulado da economia portuguesa (pouco acima de zero) situa-se 8\% abaixo do que se verificou no conjunto dos estados da zona euro. Ao contrário do que anunciaram os militantes defensores da adesão de Portugal ao euro - talvez convencidos de que ele seria uma nova 'Índia' que nos traria, como que por milagre, o leite e o mel da nossa felicidade -, ele não nos aproximou da 'Europa', muito menos do "pelotão da frente" de que falavam os 'euristas'. Está a afastar-nos aceleradamente da Europa.

No que me diz respeito, sinto-me bem acompanhado por este diagnóstico de J. Ferreira do Amaral: "Vinte anos depois - escreve o autor -, a economia portuguesa está destroçada, o estado em bancarrota, o País nas mãos de credores e sujeito a políticas ditas de ajustamento que reforçam esse domínio, os jovens portugueses desesperam e vêem-se obrigados a emigrar em massa; o desemprego ultrapassa todos os máximos anteriores; a própria sobrevivência de Portugal está em risco". ${ }^{117}$

117 Ver J. Ferreira do Amaral, Porque devemos sair do euro, cit., 15, 72, 92 e 93ss. Quando a generalidade dos trabalhadores portugueses 
empobrece aceleradamente e um número muito elevado sobrevive à custa da sopa dos pobres (eufemisticamente designadas por "cantinas sociais"), valha-nos ao menos a consolação de saber, pela comunicação social (7.11.2013), que o nosso País passou a ter 870 multimilionários (fortunas superiores a 25 milhões de euros), número que aumentou, durante o ano de 2012 (abençoada crise!), 10,8\% (a média europeia foi de 8,7\%). É bom sabermos também que a fortuna global desta nova 'aristocracia' passou de 90 mil milhões para 100 mil milhões de euros (um aumento de $11,1 \%$, superior à média europeia - 10,4\%). É bom sabermos que nem todos os portugueses sofreram as consequências do "brutal aumento de impostos" a que o governo condenou os que vivem do seu trabalho. E é claro que aqueles 'aristocratas' também não sofreram com os cortes nos salários, nas pensões e nos direitos sociais. E também não pagaram (nem pagarão) a famosa contribuição extraordinária de solidariedade. Solidários à força só os aposentados da CGA, merecedores de todos os castigos... Todos os que têm vindo a terreiro defender estas políticas de "austeridade regeneradora" (o que os homens inventam!) são, com certeza, tributários da filosofia de Hayek, segundo o qual a expressão justiça social devia ser abolida do vocabulário dos economistas.

Os resultados das políticas de austeridade são conhecidos e não são nada animadores: já em dezembro/2013, o Eurostat veio dizer-nos que $25,3 \%$ da população portuguesa está em risco de pobreza ou mesmo de exclusão social. Essas políticas têm sido 'justificadas' com o 'argumento' de que nos colocámos numa situação de devedores porque andámos (todos...) a viver acima das nossas posses. Como gente honrada, cabe-nos agora fazer das tripas coração para pagar uma dívida que contraímos cometendo um 'pecado' idêntico ao da gula. Este é um 'argumento' que convence muita gente de boa fé (por isso ele é utilizado até à exaustão). No entanto, em julho/2013, o Primeiro-Ministro português queixava-se, em Vila de Rei (para onde foi ele dizer estas verdades, lá para o Portugal profundo...), de que "a crise tem sido mais forte porque as pessoas gastaram menos do que previmos". Depois dos cortes draconianos de salários, pensões e direitos sociais e do "brutal aumento de impostos" a que os trabalhadores portugueses foram submetidos, ninguém esperaria ouvir isto do Primeiro-Ministro responsável por estas políticas. Se o OE/ 2014 for aplicado tal como o governo pretende, é inevitável que os portugueses alimentem muito menos a procura interna, provocando nova onda de recessão (baixa do PIB e aumento do desemprego). Nessa altura, o Primeiro-Ministro (que 'culpa' os portugueses pela crise da dívida, por 
Perante este quadro, tem-se discutido a questão de saber se a solução preferível para estes países não será mesmo a cessação de pagamentos, seguida da saída da Eurozona (abandono do euro) e da renegociação forçada da dívida. ${ }^{118}$

terem andado a viver a cima das suas posses) virá certamente culpar de novo os portugueses pela recessão, por teimarem em viver abaixo das suas posses..., dificultando a 'salvação da pátria', talvez apenas porque são do 'contra' e querem complicar a vida ao governo, que, por seu lado, faz o possível e o impossível para que toda a gente viva acima das suas posses...

118 Sobre esta problemática, ver C. Lapavitsas e outros, "Eurozone Crisis... e The Eurozone..., cits. Manuel Castells (ob. cit.) é uma das muitas vozes que defendem o abandono do euro por parte de países como a Espanha, por não fazer sentido "defender até ao último grego" uma moeda "que está condenada porque exprime economias divergentes e não tem um estado por trás dela". Reconhecendo que o abandono do euro "causará problemas de transição na economia e nos nossos bolsos, em condições que dependem do modo como se verificar a transição", Manuel Castells sublinha as vantagens desta opção: "recuperaríamos a soberania sobre a política económica, ajustar-se-ia a realidade monetária e financeira à economia real, incrementar-se-ia a competitividade, ganhando mercados externos e internos, haveria uma explosão de turismo [na Espanha]. Poderia reativar-se a economia emitindo moeda. E portanto incrementar-se-ia o emprego. Porque o essencial é crescer, não flagelarmo-nos".

Num livro de 2012, Francisco Louçã e Mariana Mortágua ( $A$ DÍVIDA(DURA)..., cit.) expõem, no Capítulo I da Parte I, as dificuldades e problemas que podem resultar da saída de Portugal do euro, razões perante as quais os autores concluem (p.28) que, "no contexto atual, a saída do euro é a pior de todas as soluções", solução que "só se pode aceitar quando não exista rigorosamente nenhuma outra, quando se esgotarem todas as alternativas, quando a sobrevivência o exigir". Os autores admitem, porém, que esta 'solução' possa ser-nos imposta "por vontade do diretório europeu”, mas só aceitam que ela seja encarada pelos portugueses se, "perante o descalabro das instituições e das regras europeias", a nossa independência estiver em causa e "Portugal não tiver outra solução que não seja abandonar a União Europeia e, em consequência, o euro, para recuperar a capacidade de decisão". Se se chegar a este ponto, os autores entendem ser "necessário que a maioria da população esteja 
Em Portugal, esta solução tem sido defendida por João Ferreira do Amaral, que, desde o início, mostrou reservas à criação do euro como moeda única (embora admitisse, como refiro atrás, possíveis vantagens de uma moeda comum da UE, que coexistisse com as moedas nacionais dos países que desejassem mantê-las), e que nunca viu com bons olhos a nossa entrada para o euro nas condições em que ela se verificou, por entender, pelas razões já vistas, que faltavam em absoluto os requisitos técnicos (e políticos) exigidos para o bom funcionamento de uma zona monetária ótima.

Já em junho/2011 J. Ferreira do Amaral sustentava que "os políticos têm de começar a pensar numa saída airosa do euro enquanto ainda há tempo”. Impressiona particularmente o paralelismo que faz com a situação desesperada de Portugal perante a guerra colonial, que provocou a rotura revolucionária em 25 de Abril de 1974. "A situação é comparável, com as devidas distâncias, à Guerra Colonial. Durante a guerra - alega Ferreira do Amaral - a única coisa que sabíamos é que ela não era sustentável a prazo, que teria de acabar". 119

empenhada nessa resposta, de modo a condicioná-la pela força dos movimentos populares e da defesa dos interesses do trabalho".

119 Ver o artigo de João Ferreira do Amaral em Diário de Notícias, 20.6.2011.

Não falta, de resto, quem entenda que poderá estar a aproximar-se o fim da própria UEM. Um economista muito em voga (porque se diz que 'previu' a crise atual...), Nouriel Roubini, escrevendo em meados de novembro/2011 (Cfr. Folha de S. Paulo, 13.11.2011), faz este prognóstico: "Já que a Itália é grande demais para quebrar (falir) e também para ser salva, e que agora chegou a uma situação da qual não há volta, o jogo entrou em seu período final para a zona euro. Primeiro, virão reestruturações de dívidas sequenciais e coercivas. Depois, saídas da união monetária, que terminarão na desintegração da união monetária”.

Uma fonte tão por dentro do sistema como The Wall Street Journal escreve na sua edição de 8.12.2011: “Alguns bancos centrais europeus 
No livro atrás referido (publicado já em 2013), João Ferreira do Amaral regressa ao tema, procurando explicar "porque devemos sair do euro" (é o título do livro). Depois

começaram a elaborar planos de emergência para preparar a eventualidade de um ou vários estados abandonarem o euro, ou mesmo a possibilidade da completa desagregação da união monetária europeia”.

Há mesmo quem afirme que " o Goldman Sachs, o Citygroup, o Wells Fargo, etc. apostaram biliões de dólares na implosão da moeda única" (Domingos Ferreira, ob. cit.).

Acontece que a crise do euro parece não chegar ao fim. E começa a causar problemas a países 'centrais' da UE, como a Itália, a França e a Holanda. Na Itália, além dos efeitos sobre a economia, o emprego, o défice público e a dívida externa, a crise criou as condições para que o povo italiano tivesse de suportar um governo que foi uma verdadeira "junta civil", um governo imposto pelos "mercados", um governo que inaugurou um novo ciclo de instabilidade política. Na França, está a ficar claro que nem os conservadores de Sarkozy nem os socialistas-liberais de Hollande conseguem encontrar a chave para vencer a crise, o que não é de admirar, uma vez que ambos se fornecem na farmácia neoliberal, que não tem remédios adequados para a doença de que sofre o capitalismo europeu, asfixiado pelo capital financeiro.

As nuvens negras para a UEM (e para o euro) adensam-se agora com a crise a envolver a Holanda, um dos países 'justiceiros' dos povos do sul, que condenou a duras penas por terem querido viver acima das suas posses. A verdade é que a Holanda está a braços (desde 2008) com uma 'bolha imobiliária' que não cessa de inchar, pondo em causa a estabilidade do sistema financeiro (fortemente comprometido com a especulação no imobiliário). O estado já teve de salvar um banco da falência e o preço das habitações está a baixar a um ritmo idêntico ao registado nos EUA em 2007/2008. Entretanto, prevê-se que o PIB baixe em 2013; o desemprego duplicou em dois anos e está em 8,1\%; as receitas fiscais estão a diminuir, provocando o défice das contas públicas; a dívida das famílias corresponde a $250 \%$ do PIB, índice muito superior ao registado nos 'países do sul' (Grécia, Espanha e Portugal); mais de um milhão de holandeses vive abaixo da linha de pobreza. Sendo a Holanda um país-professor no que respeita ao cumprimento dos 'deveres' impostos pelo euro, não será arriscado concluir que a raiz do problema deve estar, afinal, na natureza e na estrutura do próprio euro, que começa a esmagar os próprios pais. Estará aqui o princípio do fim do euro? 
de uma síntese muito clara das razões que, desde o início, o levaram a denunciar o erro da nossa adesão ao euro, faz um diagnóstico das consequências desta decisão errada, com base no qual defende que a própria salvaguarda da nossa sobrevivência como país independente aconselha a saída do clube do euro. ${ }^{120}$

Outro defensor da saída de Portugal do euro é Octávio Teixeira. Num texto de novembro/2012 defende que a saída do euro "é uma necessidade objetiva para a viabilização do País". ${ }^{121}$ Invocando os efeitos negativos para a economia portuguesa da sobrevalorização do euro a partir de 2003 (que estima entre $30 \%$ e $40 \%$ ), sustenta que o relançamento da economia com base no aumento da produção só é viável se forem repostos os equilíbrios estruturais da economia, o que exige necessariamente a "adequação do preço da moeda à realidade e à estrutura económicas do País". Por outras palavras: o aumento da produção em condições de compe-

${ }^{120}$ Embora com diferente enquadramento ideológico, também Pedro Braz Teixeira (ob. cit., 149) aponta deficiências estruturais ao euro, sustenta que o euro tem sido um fracasso (em termos nacionais e em termos europeus), concluindo que "o euro não tem condições de sobrevivência”. No que diz respeito à nossa participação no euro, entende que não foi uma boa opção, que "a gestão macroeconómica da [nossa] adesão ao euro não podia ter sido pior" e conclui que da nossa permanência no euro (se ele sobreviver...) só podem esperar-se salários quase congelados e desemprego mais elevado, com muita dificuldade em diminuir. Nas páginas 161 ss pode ver-se uma síntese dos argumentos que, segundo o Autor, podem invocar-se a favor e contra a manutenção do (no) euro.

Analisando os prós e os contras da saída de Portugal do euro, também Nuno Teles e Alexandre ABreu se inclinam a favor do abandono do euro pelo nosso País: "Democracia é poder decidir o nosso futuro. Sair do euro não é uma condição suficiente, mas é uma condição necessária”. Cfr. "Sair do euro..., cit.

A problemática de um eventual abandono do euro por parte de Portugal é também equacionada no artigo, já citado, de João GaLAmBA.

121 Cfr." Sair do euro..., ob. cit. 
titividade externa (quer no que toca às exportações quer no campo da substituição de importações) tem de passar pela "desvalorização estrutural da moeda, o que implica a saída do euro e a recuperação da soberania monetária”. Sem se dar este primeiro passo, conclui o Autor, nenhuma estratégia de re-industrialização do País será viável.

Num artigo de 2013, Carlos Carvalhas analisa também a problemática da saída de Portugal do euro e, se bem vejo, a sua análise não anda longe dos pontos de vista que eu próprio venho defendendo. Escreve o Autor: "O debate não se pode situar, nem numa saída com simplicidade esquemática, nem num quadro de apocalipse wagneriano, no estilo dos helicópteros do filme de Coppola". (...) "A saída é complexa; tem desde logo consequências difíceis, negativas, já referenciadas por muitos, pelo que teria de ser negociada e compensada, pois ela também poderá trazer beneficios para a zona euro, designadamente para o seu núcleo duro - Alemanha, Holanda, Finlândia e Áustria. Por isso, a negociação e a compensação, podendo trazer benefícios para várias partes, pode tornar-se realista". ${ }^{122}$

24. Pela minha parte, pesando bem as suas consequências no plano da economia e no plano social, entendo que uma decisão unilateral de saída do euro não pode ser tomada de ânimo leve.

Salientam alguns autores que "não é fácil apurar o que acontecerá no interesse dos trabalhadores da periferia, para não falar dos do centro". Apesar de tudo, parece que querem deixar uma perspetiva optimista: "se fosse seguido o caminho do não pagamento, renegociação da dívida e saída do euro, ele conduziria a uma mudança na correlação de forças em

${ }^{122}$ Cfr." $\mathrm{O}$ euro..., cit. 
favor do trabalho. Por isso ele quebraria as amarras do conservadorismo e do neoliberalismo na Europa". ${ }^{123}$

A verdade, porém, é que, em regra, os que defendem a saída do euro (invocando alguns a experiência paralela - mas não idêntica - da Argentina, na sequência da crise que a afetou no início da década de 2000) sublinham que a solução em análise arrastaria consequências dificeis de enfrentar. E não se vê como é que a opção pela saída do euro poderia provocar, por si mesma, a referida alteração na correlação de forças em sentido favorável aos trabalhadores. O que poderá dizer-se é que a decisão de 'sair do euro' seria mais fácil de tomar e teria talvez consequências menos gravosas se se verificasse, no país em causa, uma correlação de forças favorável aos trabalhadores e às suas organizações. Creio que, neste momento, não é esta a situação, nem em Portugal nem em nenhum dos demais países vítimas do sistema da moeda única e da especulação contra o euro.

A meu ver, uma análise fria da situação obriga a admitir que os riscos de uma tal decisão são sérios e de vária ordem. Para além dos riscos de fuga de capitais e até de corrida aos bancos para levantamento dos depósitos, o abandono do euro implicaria uma desvalorização muito acentuada da nova/ velha moeda (à roda de 50\%, estimam alguns especialistas).

Reconheço sem dificuldade que Portugal precisa de desvalorizar a moeda com que opera, porque com a adesão ao euro sofremos uma sobrevalorização não inferior a 40\%, que constitui uma barreira muito forte à nossa competitividade (nos mercados externos e no mercado interno) e à nossa capacidade de crescimento económico. E sei bem que essa desvalorização não é possível no quadro da UEM.

Não podemos esquecer, porém, que as políticas seguidas nos últimos trinta anos se traduziram numa verdadeira ges-

123 C. Lapavitsas e outros, The Eurozone..., cit., 47/48. 
tão danosa de fundos públicos, assente em esquemas de alta corrupção, para enriquecer clientelas (são casos notórios os fundos destinados à agricultura e à formação profissional) e para favorecer as atividades económicas centradas em produtos não-transacionáveis (auto-estradas e grande distribuição), cujo financiamento é responsável por uma boa parte da dívida externa portuguesa. A gestão dos fundos comunitários, em vez de promover a necessária reestruturação e modernização da nossa economia e a melhoria da qualificação académica e da formação profissional dos trabalhadores portugueses, orientou-se no sentido da destruição da nossa estrutura produtiva, deitando fora os investimentos feitos na siderurgia, na metálico-mecânica pesada, na construção naval, na marinha mercante, e liquidando a nossa agricultura e as nossas pescas.

É certo que a desvalorização potencia o aumento das exportações e dificulta as importações, ajudando a resolver, conjunturalmente, os problemas da balança de pagamentos correntes. Mas não pode esquecer-se que o valor das exportações portuguesas inclui $40 \%$ de bens importados (nomeadamente combustíveis, matérias-primas, equipamentos, know how), cujos preços aumentariam por força da desvalorização, arrastando consigo o aumento dos custos e dos preços dos produtos exportados.

Isto significa que a desvalorização resultante da saída unilateral do euro arrastaria consigo dificuldades não descartáveis no que toca ao crescimento económico (e, portanto, à criação de emprego), uma vez que o país teria de pagar muito mais caros os bens que temos de importar para nos alimentarmos e para continuar a produzir (e, por maioria de razão, para acelerarmos o ritmo do crescimento económico). Acresce que a inflação resultante da desvalorização da nova moeda reduziria o poder de compra dos salários, com a consequente diminuição da procura interna, o que afetaria ne- 
gativamente o conjunto (importante) das pequenas e médias empresas (trabalho-intensivas) que produzem essencialmente para o mercado interno, reduzindo o crescimento e aumentando o desemprego.

A desvalorização da moeda traria também novas dificuldades no acesso ao crédito junto dos mercados internacionais e significaria também o aumento significativo dos encargos da dívida externa (amortização do capital e juros), a pagar em euros. ${ }^{124}$

Também não se pode ignorar que, para países de tecnologia intermédia, como Portugal, a concorrência no mercado externo não é fácil, porque é necessário enfrentar produtos de tecnologia idêntica provenientes de países com custos de mão-de-obra inferiores aos nossos.

Apesar de tudo, creio que há boas razões para pensar que as consequências negativas da (forte) desvalorização da moeda e da inflação dela resultamte podem ser menos gravosas do que a chamada desvalorização interna (tão acarinhada por alguns expoentes da ideologia neoliberal, lá fora e no nosso País), operada diretamente através dos cortes nos salários, nas pensões e nas prestações sociais do estado, ou seja, através do empobrecimento das pessoas e das famílias e dos portugueses enquanto povo, assim reduzido a um estatuto próximo do das colónias à moda antiga.

Como o peso dos salários nos produtos em que assentam as exportações portuguesas é relativamente pequeno nos custos totais $(25 \% / 30 \%)$, mesmo um corte 'terrorista' nos salários de 30\% não traria um aumento de competitividade superior a 9\%. Uma desvalorização da moeda de 30\% produziria efeitos muito mais rapidamente e de maior impacte na dita competitividade, com a vantagem acrescida de que os

${ }^{124}$ Quanto a este último ponto, não falta, porém, quem entenda (com alguma razão) que a inflação "é a melhor receita para reduzir dívidas". Assim, M. Castells, ob. cit. 
efeitos da desvalorização da moeda beneficiariam os setores dos bens transacionáveis (os bens exportados ou que substituem importações), enquanto a redução dos salários atinge todos os setores (incluindo os que dominam monopolisticamente o mercado interno) e gera consideráveis efeitos recessivos na economia.

Por outro lado, embora desfavorável para os que vivem dos rendimentos do trabalho, a desvalorização da moeda atinge mais generalizadamente todos os estratos sociais do que a referida desvalorização interna, que se abate exclusivamente sobre os salários e as pensões.

Antecipando alguns dos custos da desvalorização da moeda, Octávio Teixeira admite que dela resultaria alguma pressão inflacionista, calculando que uma desvalorização de $30 \%$ da nova moeda provocaria uma inflação entre $8 \%$ e $9 \%$, da qual resultaria uma diminuição dos salários reais à volta destes valores. Em sentido contrário, argumenta que as políticas adotadas desde 2011, no quadro do euro e por causa do euro, já provocaram uma erosão do poder de compra dos salários superior à que estima como consequência da saída do euro.

Sabendo que as exportações portuguesas contêm uma percentagem importante de bens e serviços importados, Octávio Teixeira, faz as contas com base nas matrizes input-output da nossa economia divulgadas pelo INE e conclui que uma desvalorização de $30 \%$ da futura moeda portuguesa provocaria uma baixa dos preços das exportações de cerca de $24 \%$, com efeitos positivos imediatos no aumento da produção e do emprego, dando início a um novo ciclo de crescimento económico. ${ }^{125}$

125 Em maio/2013, o Autor retoma o tema, num artigo publicado em Le Monde Diplomatique (cit.) e conclui nestes termos: “A questão a colocar é a de como sair do euro, tão cedo quanto possível, e preparar essa saída para limitar os efeitos negativos". 
25. A solução da saída do euro implicará sacrifícios, sem dúvida. No entanto, parafraseando Manuel Castells, reconheço ser imperioso impedir que o povo continue a ser flagelado e continue a autoflagelar-se, por culpas que não lhe cabem. E entendo que é igualmente imperioso, para um país como Portugal, recuperar a sua soberania monetária e cambial, que significa a capacidade de decidir soberanamente em questões tão centrais como o recurso à emissão de moeda para financiar políticas públicas, o recurso à manobra da taxa de juro para condicionar e orientar as políticas de investimento e de consumo, o recurso à variação da taxa de câmbio para facilitar a reestruturação do nosso tecido produtivo e para enfrentar dificuldades externas de natureza conjuntural.

Não faltam razões aos que defendem que a continuação da nossa permanência na Eurozona só agravará a nossa dependência, desequilibrando ainda mais a nossa estrutura produtiva, que já apresenta um peso muito pequeno da indústria (à volta de $15 \%$ do $\mathrm{PIB}$ ) e um peso quase insignificante do setor primário ( $2 \%$ a $3 \%$ do $\mathrm{PIB})$. Depois dos 'aperfeiçoamentos' introduzidos na estrutura da UEM, com as 'regras de ouro' do Tratado Orçamental e da União Bancária, a permanência na zona euro pode significar, para o nosso País, a incapacidade permanente para se desenvolver autonomamente, o empobrecimento humilhante e aniquilador do povo português, a nossa redução a um estatuto 'colonial'.

Perante uma 'Europa' governada por dirigentes que, por falta de estatura política, intelectual e moral, ignoram a profunda crise existencial em que vivemos, aceitando sacrificar tudo à estratégia eleitoral da Sr. ${ }^{a}$ Merkel, a hipótese de saída do euro não pode descartar-se em absoluto, sobretudo para países como o nosso.

Creio, aliás, que a ausência de crescimento da Europa do euro, as crescentes dificuldades colocadas pela crise do euro 
e as políticas cada vez mais violentas impostas pelos países dominantes aos países mais débeis, acentuando a divergência entre os níveis de desenvolvimento e de condições de vida de uns e outros, são fatores que vêm reforçando a razão dos defensores da saída do euro e vêm tornando esta hipótese cada vez mais plausível (talvez inevitável). Serge Halimi faz uma espécie de ponto da situação a este respeito que vale a pena transcrever aqui: "Neste momento, já todos compreenderam que a moeda única e a quinquilharia institucional e jurídica que a sustenta (Banco Central independente e Pacto de Estabilidade e Crescimento) impedem qualquer política que combata, ao mesmo tempo, o aprofundamento das desigualdades e o confisco da soberania por uma classe dominante subordinada às exigências do sistema financeiro". ${ }^{126}$

Não parece legítimo pedir aos povos destes países que continuem a suportar sacrificios cada vez mais duros e humilhantes para salvar uma 'Europa' sem identidade nem fronteiras, uma 'Europa' sem projeto, uma 'Europa' que não passa de um grande mercado unificado, à medida dos interesses das grandes potências europeias (nomeadamente a Alemanha), uma 'Europa' governada pelo grande capital financeiro com a cumplicidade de uma mega-estrutura de tecnocratas neoliberais regiamente pagos. Conhecendo esta 'Europa', os 'países do sul' só terão a ganhar se forem discutindo e concertando entre si as suas ideias acerca das propostas a apresentar em conjunto às instituições da UE sobre a definição de uma estratégia global para uma eventual 'saída do euro', de modo a conseguirem reduzir ao mínimo as consequências negativas dessa decisão, se ela vier a revelar-se inevitável.

Uma estratégia possível talvez pudesse passar pelo regresso a uma das hipóteses muito discutida antes da criação da UEM e que, com certas variantes, tem sido equacionada

${ }^{126}$ Ver "Estratégia..., cit. 
por alguns autores. Refiro-me à consagração do euro como moeda comum da UE (a única convertível em moedas de países exteriores a esta zona euro mais reduzida e com novo figurino), que teria o estatuto de moeda de reserva para as moedas nacionais dos países integrantes desta nova zona monetária mais flexível. No seio desta zona monetária, alguns países que entre si reunissem os requisitos técnico-políticos exigidos por uma zona monetária ótima poderiam continuar a adotar o euro como a sua moeda, mas os países que não podem suportar uma moeda tão valorizada poderiam recuperar a sua moeda nacional, recuperando do mesmo passo a soberania em matéria de política monetária e cambial (possibilidade de recurso à emissão de moeda para financiar as políticas públicas, controlo autónomo das taxas de juro, possibilidade de desvalorização da moeda, possibilidade do controlo dos movimentos de capitais). ${ }^{127}$

Bem vistas as coisas, talvez a saída o euro seja o caminho da 'libertação' para os países que, manifestamente, não têm uma economia capaz de suportar uma moeda tão forte e com as 'regras' que a acompanham (concebidas para 'domesticar' os povos destes mesmos países, considerados incapazes de autogoverno pelos 'estados dominantes') e que não podem esperar da União Europeia (dada a sua natureza e o seu modo de funcionamento) a solidariedade e o impulso para que possam atingir níveis de desenvolvimento compatíveis com uma moeda do tipo do euro.

127 Em artigo recente, F. LORDON ("Sair do euro..., cit) defende o abandono deste "euro liberal" ou "euro anti-social", apontando a criação de uma moeda comum (talvez não recomendável para todos os atuais países do euro), que permitisse um grau maior de autonomia aos diferentes países no que toca à emissão de moeda, à desvalorização externa da moeda nacional, aos níveis de inflação, à política de taxa de juro, ao montante da dívida pública e do défice das contas públicas. 
Por outro lado, talvez a saída destes países mais débeis do clube do euro seja vista também como uma 'libertação' para os países dominantes, que deixarão de perder tempo com as perturbações e os desequilíbrios provocados pelas deficiências estruturais da atual UEM.

Se este diagnóstico for correto, talvez possam reunir-se as condições que evitem uma saída do euro unilateral (litigiosa), por parte de países como Portugal, condições que permitam que esta saída seja convenientemente preparada, no plano técnico e no plano político, no âmbito de um acordo negociado com as autoridades da UE.

Vale a pena refletir sobre um outro aspeto. Se bem vejo, a saída do euro só faz sentido se for enquadrada por um conjunto de medidas que teriam de passar pela nacionalização da banca e pelo controlo dos movimentos de capitais ${ }^{128}$; pela nacionalização de setores estratégicos da economia (nomeadamente os serviços públicos, a energia, os transportes, as telecomunicações); por uma política económica voltada para o aumento da produção, valorizando os recursos naturais e humanos; pela reforma do estado, para acabar com a corrupção e instituir mecanismos de eficiência administrativa e de

128 O problema é que a nacionalização transfere para a titularidade do estado o capital e os créditos dos bancos, mas transfere também as suas dívidas (dívidas para com os depositantes e dívidas para com os seus credores, em regra outros bancos estrangeiros). Se os créditos dos bancos (junto das famílias, das empresas e da administração pública) passarem a ser denominados na nova moeda desvalorizada (como é desejável e inevitável do ponto de vista das famílias e das empresas, que passam a receber os seus rendimentos nesta moeda), os bancos ficarão em grande dificuldade, com um enorme desequilíbrio nos seus balanços, porque vêem os ativos desvalorizados, mas as suas dívidas para com o estrangeiro continuam a ser denominadas e a ter de ser pagas em euros. E a dívida dos bancos nacionalizados passa a ser dívida do estado português, que poderá ser obrigado a reforçar fortemente o capital desses bancos para evitar a sua falência. 
transparência governativa; pelo combate à evasão e à fraude fiscal; pela tributação mais pesada das grandes fortunas e dos rendimentos do capital e pela redução dos impostos indiretos; por grandes investimentos (semeadores de futuro) na educação, ciência e tecnologia, na saúde e nas políticas tendentes a reduzir significativamente as desigualdades sociais.

Todos concordaremos que este programa político só poderá levar-se a cabo por decisão soberana do povo português e só terá êxito se existirem condições que configurem uma correlação de forças favorável aos trabalhadores e às suas organizações sindicais e políticas.

Mas, para além de um forte apoio social interno, este programa terá de contar com um reconhecimento internacional que respeite a opção dos portugueses, que não empurre o país para a autarcia e que o liberte de um qualquer bloqueio imposto pelas potências imperialistas.

Até hoje, a 'Europa' do deutsche euro tem-se limitado a punir exemplarmente os 'países do sul', condenando-os a pagar sozinhos o custo dos desequilíbrios estruturais provocados pelo euro (em desfavor dos países mais débeis), bem como o custo desta crise do euro e da especulação contra o euro.

À luz da história, entendo, porém, que a UE e os seus estados-membros têm o estrito dever de ajudar estes países a reduzir o impacte negativo do abandono do euro. E o BCE terá de assumir também a sua quota de responsabilidades, ajudando a diminuir o peso da dívida pública externa (por exemplo, permitindo a Portugal a sua recompra em condições favoráveis). É o mínimo que se lhes pode exigir.

26. Resta uma questão por resolver. A saída do euro não nos livrará das sujeições resultantes da permanência nesta União Europeia, com as suas 'regras do jogo' neoliberais, que conduziram à desestruturação do nosso tecido industrial (e consequente desindustrialização), à destruição da nossa agri- 
cultura, ao abandono da pesca e do aproveitamento dos recursos marinhos, ao desmantelamento da marinha mercante e da construção naval, em suma, à destruição da nossa capacidade de desenvolvimento autónomo.

Ora a saída do euro não significa a nossa 'libertação' das regras do jogo da Europa neoliberal: a entrega aos 'mercados' do 'governo' da economia e da sociedade (economia de mercado regulada e economia social de mercado); a liberdade absoluta de circulação de capitais; as regras da concorrência e das ajudas de estado, ao serviço dos interesses dos mais fortes; as exigências asfixiantes ("estúpidas" e "medievais") do Tratado de Maastricht e do PEC; a perda da autonomia financeira resultante do Pacto Orçamental; a perda de influência relevante na definição das políticas comunitárias, sobretudo depois da integração na UE dos países do centro e do leste da Europa que integram o 'espaço vital' da Alemanha, e, de modo irreparável, depois da entrada em vigor das novas regras de funcionamento aprovadas no Tratado de Lisboa (em virtude das quais desapareceu, na prática, a votação por unanimidade, a 'bomba atómica' dos pequenos países).

27. $\mathrm{Na}$ situação atual, não admira que os povos da Europa não tenham a "consciência de partilhar um destino europeu comum" e faz sentido a preocupação de muita gente quanto à "possibilidade real do fracasso do projeto europeu". ${ }^{129}$

Tem razão Ulrich Beck quando defende que "a crise do euro tirou definitivamente a legitimidade à Europa neoliberal". ${ }^{130}$ É notório o descrédito do neoliberalismo no plano teórico e não há como esconder os resultados calamitosos das políticas neoliberais. Mas a verdade é que os

129 É o caso de Jürgen Habermas, ob. cit., 66, 136, 139, 161 e 167.

130 Cfr. U. BECK, ob. cit., 111. 
partidos do 'arco do poder' (que assim se assumem, como que confiscando a liberdade de escolha dos cidadãos eleitores) continuam, por toda a Europa, fiéis à tese de que não há alternativa às políticas de austeridade de inspiração neoliberal. Os reformistas de vários matizes estão, verdadeiramente, num impasse. O projeto de Habermas de "civilizar e domesticar a dinâmica do capitalismo a partir de dentro" não parece viável, porque, como o próprio Habermas reconhece, a 'filosofia' e as consequências das políticas neoliberais são "dificilmente conciliáveis com os princípios igualitários de um estado de direito social e democrático". A submissão da Europa neoliberal ao Consenso de Washington (mantendo Keynes 'morto' e ignorando o consenso keynesiano) nega qualquer viabilidade a propostas como a de Ulrich Beck: um novo contrato social europeu, "uma nova era social-democrata a nível transnacional". ${ }^{131}$

Não sendo de esperar, com as atuais lideranças europeias, que possa concretizar-se o seu desejo de "aprofundamento da cooperação europeia", Habermas vai ao ponto de defender que a UE se encontra numa encruzilhada entre "um aprofundamento da cooperação europeia e o abandono do euro". 132

E Ulrich Beck sustenta que todos os povos da Europa estão a ser vítimas da crise financeira e das políticas [deliberadamente, digo eu. AN] erradas adotadas para a enfrentar. Em resultado destas políticas, sublinha o sociólogo alemão, "os países devedores formam a nova 'classe baixa' da UE", e "têm de aceitar as perdas de soberania e as ofensas à sua dignidade nacional". A seu ver, tornou-se ambíguo o significado da cooperação e da integração europeia, sendo que a principal vítima desta ambiguidade é justamente "esta nova

131 Cfr. Ulrich BeCK, ob. cit., 93ss.

132 As citações de J. Habermas reportam-se à ob. cit., 135-140, 153/154, 157 e 168/16. 
classe baixa da Europa" (os países devedores). "O seu destino - conclui Beck - é incerto: na melhor das hipóteses, federalismo; na pior das hipóteses, neocolonialismo". ${ }^{133}$ Venha o diabo e escolha... Por mim, receio que, nestes tempos e com esta 'Europa', a ‘solução’ federalista não será mais do que uma forma de (ou um caminho para o) neocolonialismo.

O que nós sabemos é que as políticas de austeridade - impostas por esta 'Europa', pelas troikas, pelos FMI, pelos Goldman Sachs, pelas Comisssões Trilaterais, pelos G 20, pelos Forum Davos, em suma, pelas centrais do capital financeiro organizado (pelas centrais reguladoras do crime sistémico) “equivalem a um esvaziamento da autodeterminação", i.é, da capacidade e do direito de decidir sobre o próprio destino coletivo. Não admira, por isso, que "a adesão a esta ideia de mais Europa seja cada vez mais reduzida nas sociedades dos estados-membros da UE“. A conclusão é de Ulrich Beck, que, deste modo, parece reconhecer que a mais provável das duas hipóteses que coloca (como digo atrás) é a da condenação dos países mais fracos da UE ao estatuto de colónias. ${ }^{134}$

Nas condições atuais de verdadeiro retrocesso da democracia, a realidade mostra a absoluta inviabilidade de um federalismo a sério, porque esta Europa alemã está a anos-luz de poder garantir os pressupostos exigidos por um autêntico federalismo. A presente crise do euro veio pôr a nu a desunião europeia, mostrando que a 'Europa' é um terreno pantanoso, movediço e falso, inapto para nele se construir algum edifício com um mínimo de solidez. E tornou evidente que a Europa do capital não é um espaço solidário, um espaço em que seja possível a cooperação entre iguais, mostrando que a 'Europa' vive já em regime de colonialismo interno: uns (poucos) países são metrópoles, outros são colónias.

133 Cfr. Ulrich BECK, ob. cit., 21 e 64.

134 Ob. cit., 12 e 15. 
Se este diagnóstico é correto, então não faz sentido qualquer aprofundamento da integração política na Europa. A ideia de mais Europa não passa de um slogan destinado a alimentar mais um processo de 'fuga para a frente', com o argumento falacioso de que o grau avançado de integração económica e (sobretudo) monetária a que se chegou não é sustentável se não se avançar para um nível correspondente de integração política, que abranja outras áreas para além da economia.

O federalismo possível não passaria, pois, de um falso federalismo, com a centralização do poder em estruturas tecnocráticas carecidas de legitimidade democrática, que, incapazes de fazer política (i.é, de exercer a soberania), se limitariam mais do que já fazem hoje - a 'cumprir regras'. Ora as 'regras de ouro' e outras menos 'douradas', definidas pelos “mercados", pelo grande capital financeiro, pelas redes do crime sistémico, visam, como disse atrás, sujeitar os 'povos do sul' a um novo colonialismo, impedindo-os de gerir o seu presente e de decidir sobre o seu futuro. ${ }^{135}$

135 Um homem que conhece tão bem a 'Europa' como Jean-Claude Juncker não foi capaz de calar o que lhe vai na alma, declarando, numa entrevista (era então Presidente do Euro-Grupo), que "a Alemanha trata a zona euro como se fosse uma sua filial” (Jornais de 30.7.2012).

Como recordei atrás, num congresso do seu partido (Leipzig, novembro/2011), o secretário-geral do partido da Sr. ${ }^{a}$ Merkel proclamou: "Agora na Europa fala-se alemão".

Em artigo publicado na revista Merkur (uma revista muito influente junto da intelectualidade alemã), em janeiro/2012, o seu autor (Christoph Schoënberger) defende que a hegemonia da Alemanha no seio da UE deve ser entendida como a hegemonia que cabe (como que naturalmente) ao estado mais poderoso no seio de um sistema federal, à semelhança do que aconteceu com a Prússia no seio da federação germânica durante o II Reich: "sendo os estados representados no Conselho Europeu muito desiguais em dimensão e peso, seria irrealista pensar que eles podem coordenar-se em pé de igualdade. (...) "Para funcionar, a União exige que o estado com mais população e riqueza lhe dê coesão e direção. A Europa 
Todos concordaremos que não há um povo europeu. E todos concordaremos em considerar fora de qualquer propósito a proposta, já trás referida, de Dominique Strauss-Kahn: "Fizemos a Europa, agora é preciso fazer os europeus". ${ }^{136}$ Insisto em lembrar a conclusão da Habermas: os povos da Europa não têm a "consciência de partilhar um destino europeu comum". A Europa continua a ser um espaço "com falta de definição e de limites", marcado pela "insegurança identitária”, um espaço que não conseguiu anular, perante cada um dos cidadãos e cada um dos povos da Europa, o papel do estado-nação como a matriz e o espaço da soberania, da liberdade e da cidadania.

A ideia, que alguns defendem, de que temos de criar um estado europeu só porque já temos uma união monetária que precisa de um estado para sobreviver é tão absurda como

precisa da hegemonia alemã, e os alemães têm de deixar de se mostrar tímidos no seu exercício".

Os trechos transcritos são a síntese de P. Anderson, ob. cit. que comenta: "A França, cujo arsenal nuclear e lugar no Conselho de Segurança da ONU já não contam grande coisa, tem de rever, por isso, as suas pretensões. A Alemanha deve tratar a França como Otto Von Bismarck fez com a Baviera nesse outro sistema federal que foi o II Reich, mimoseando o parceiro inferior com favores simbólicos e consolações burocráticas". E acrescenta que Bismarck considerava os bávaros "a meio caminho entre um austríaco e um ser humano". Pergunta Parry Anderson: "Irá a França aceitar assim tão facilmente ser rebaixada ao estatuto que foi o da Baviera no II Reich?”. Pergunto eu: aceitarão os povos da Europa oferecer à Alemanha, de mão beijada, o que Hitler não conseguiu pela violência e pela barbárie?

A Alemanha poderá, finalmente, tornar-se a potência hegemónica da Europa, ambição que parece não abandonar os dirigentes alemães. Esta Europa poderá até falar alemão, poderá até aproximar-se do "quarto Reich" de que falam alguns, recuperando a expressão cunhada, em 1995, pelo historiador inglês Andrew Roberts. Mas uma Europa de servos não será nunca uma Europa de desenvolvimento e de paz.

136 Apud J.-P. Chevènement, ob. cit., 54 e 183. 
a absurda proposta de Dominique Strauss-Kahn. Tendo presente que de muitos lados vem a ideia de que a raiz das dificuldades da 'Europa' está na filosofia que inspirou a sua construção e nas estruturas e regras de funcionamento da UE, nomeadamente após Maastricht (com a "fantasia" da UEM, o euro, o BCE e o PEC, a que depois se juntaram o Tratado de Lisboa e o chamado Tratado Orçamental), tenho para mim que seria um erro gravíssimo embarcar numa "fantasia" muito mais perigosa (a da federalização da Europa), na mira de resolver (ou contornar), com este salto no escuro, erros anteriores.

Devo dizer que não rejeito, em absoluto (no plano filosófico), a ideia de um estado federal europeu. Mas quero igualmente deixar claro que, neste mundo que hoje conhecemos, não vejo nenhuma vantagem que possa resultar da integração de Portugal num qualquer estado federal europeu, com perda absoluta da nossa soberania.

A verdade é que os portugueses deram novos mundos ao mundo e chegaram, pelo seu próprio pé (ou pela sua própria caravela), aos quatro cantos do mundo. E, em boa medida, a nossa presença mantém-se nos cinco continentes, sobretudo no plano cultural. Parafraseando Virgílio Ferreira, podemos dizer que da nossa língua (a língua portuguesa) vêem-se os mares do mundo inteiro.

Não quero ser 'romântico' e detesto o patrioteirismo, mas acredito que a preservação deste património (a nossa presença no mundo e a nossa capacidade de relacionamento com todos os povos do mundo) é fundamental para escaparmos ao destino de periferia colonial para que nos querem empurrar, amarrados a uma dívida que nunca conseguiremos pagar, embrulhados em euros (poucos..., e cada vez menos) e manietados por regras de ouro e outras 'regras' que nos estão a asfixiar como povo soberano. 
O que quero dizer é que, enquanto não mudarmos as 'regras de vida' da Europa e do mundo, não vejo razões que me convençam da bondade do federalismo europeu, que significaria, para o nosso País, a perda daquele património valioso que fomos acumulando ao longo de séculos (séculos de aventuras e desventuras, de heroísmos e de cobardias, de grandezas e de misérias).

Acresce que ninguém ainda definiu o que é a Europa e quais as suas fronteiras. E ninguém parece interessado em fazê-lo. $O$ processo de integração europeia tem sido um grande 'negócio'. E os 'negociantes' não gostam de perder nenhuma oportunidade de bons negócios...

Por outro lado, a 'desunião europeia' destes anos de crise só veio confirmar que não há condições mínimas para se poder esperar que, como estados federados, os estados europeus se assumam, no seio da federação, como estados iguais uns aos outros (esta igualdade é assegurada atualmente nos Tratados, mas é visível que uns são mais iguais do que os outros...). Os passos dados à sombra da bandeira de mais Europa política, a caminho da Europa federal, têm reforçado sempre a deficiência democrática do processo de construção europeia, têm imposto uma 'Europa' construída "à porta fechada", têm acentuado o domínio dos grandes sobre os pequenos, sacrificando a dignidade destes últimos (dos estados e dos 'povos do sul'), tratados como colónias ou como filiais. Em função do calendário eleitoral da Alemanha, a 'Europa' fica parada à espera dos resultados saídos dos votos dos eleitores alemães, e os governantes de serviço e os comentadores pagos por estes falam disto como se se tratasse de uma coisa natural, resultante de algum tratado internacional ou de algum 'princípio superior' que prevalece sobre tudo o resto...

O comportamento da 'Europa' ao longo destes anos de crise veio reforçar a minha convicção de que a proposta de se avançar para a construção de um estado federal europeu 
não parece ser um objetivo político minimamente realista, nem chega a ser uma utopia: é uma impossibilidade, é uma quimera que nem em sonhos se concretiza. Não passa de uma pura fuga para a frente, ou um salto para o lado, para não encarar e resolver os problemas que nos afligem e para fugir às soluções que acautelem o nosso futuro. Num artigo recente, Serge Halimi veio defender ponto de vista idêntico ao que venho sustentando publicamente desde 2006 $6^{137}$ : "No estado atual das forças políticas e sociais, uma Europa federal só poderá consolidar ainda mais os dispositivos liberais que já são asfixiantes e desapossar o povo, um pouco mais, da sua soberania, entregando o poder a opacas instâncias tecnocráticas". ${ }^{138}$

Uma 'Europa' que vem 'matando' a política substituindo-a por regras de ouro de cumprimento mecânico (por parte dos países mais fracos, é claro) não pode alimentar nenhum estado federal sério, que tem de assentar na igualdade entre os estados federados e no respeito da capacidade de decisão política no âmbito das competências de cada um dos estados federados e de cada um dos órgãos políticos representativos do estado federal. Alguém pensa que a Alemanha (e outros países da atual UE) aceitará considerar-se igual a Malta ou a Portugal? Alguém concebe que a Alemanha aceitará alguma vez sujeitar-se às decisões políticas dos órgãos federais, que poderiam querer, por exemplo, alterar os estatutos do BCE, ou revogar o PEC?

$\mathrm{Na}$ minha leitura, os construtores desta 'Europa' (incluindo os dirigentes dos partidos que integram o espaço da social-democracia europeia) não mostraram, até hoje, o mínimo interesse em analisar a fundo as raízes da crise atual, o que significa que não estão interessados em aproveitar as lições da presente crise para fazer um balanço crítico da sua

137 Cfr. A Constituição Europeia..., cit.

138 Cfr. “Onde está a esquerda?”, cit., 9. 
reflexão e da sua atuação nas últimas décadas. A sua preocupação continua a ser a de gerir lealmente o capitalismo. Perante o espetáculo da desunião europeia e da ‘colonização’ da Europa pela Alemanha imperial, não tiveram o rebate de consciência de reconhecer que é preciso mudar a 'Europa' que puseram de pé, uma estrutura neoliberal ao serviço do grande capital financeiro. Nestes anos de aperto, nem sequer tiveram a 'coragem' de regressar a Keynes, à defesa de uma direção centralizada da economia (ainda que esta continue maioritariamente nas mãos do capital privado), à defesa da regulamentação do setor financeiro (contrária à especulação e aos jogos de casino), à defesa do controlo público da poupança nacional e dos investimentos estratégicos. Continuam fiéis ao lema thatcheriano de que não há alternativa ao mercado e ao capitalismo e recusam libertar-se da dependência 'química' do neoliberalismo.

Pela minha parte, acredito que os povos da Europa não aceitarão ser transformados em "uma futura sub-província alemã no âmbito da 'marca' alemã'. ${ }^{139}$ Mais cedo ou mais tarde, hão-de recuperar a sua liberdade e a sua soberania, ocupando o seu lugar de protagonistas e fazedores da História. E então, em condições completamente diferentes, talvez pensem em construir uma Europa solidária, uma Europa para os povos europeus, assente na paz e na cooperação entre eles e com todos os povos do mundo.

28. No ambiente atrás definido, são cada vez mais as vozes que põem em equação os perigos para a democracia na Europa. As preocupações quanto à preservação da democracia adensam-se quando vemos que os estados se vêm comportando, às escâncaras, como estados de classe, não escondendo o seu compromisso com o grande capital financeiro e mostrando que estão dispostos a tudo (e o estado

139 A expressão é do Gen. Loureiro dos Santos (Público, 19.6.2012). 
capitalista já mostrou que é capaz de tudo!) para impor as suas políticas de 'punição' e de agravamento da exploração dos trabalhadores.

Portugal é um bom exemplo do que acabo de escrever. O Primeiro Ministro gosta de repetir que o diktat da troika tem de ser cumprido "custe o que custar". Para tanto, faz aprovar leis e mais leis que sabe serem inconstitucionais, comportamento deliberado que considero uma clara atitude de provocação ao Tribunal Constitucional (TC), integrada numa estratégia de desgaste deste Tribunal, acreditando talvez no velho ditado segundo o qual água mole em pedra dura, tanto bate até que fura (colocado perante tantas inconstitucionalidades, o TC acabará por deixar passar algumas...). O número dos que vêm subindo ao palco para chantagear o TC e até para ofender a sua dignidade como órgão de soberania cresceu, aliás, com a aproximação do momento da entrega na Assembleia da República da proposta de lei do orçamento de estado para 2014.

Já não são apenas uns quantos secretários de estado mais ou menos analfabetos e insolentes (como é próprio dos ignorantes) a falar do verdadeiro finis patriae que resultaria de um eventual 'chumbo' de algumas normas do orçamento de estado por aquele Tribunal. Nem é só o Primeiro Ministro a falar da falta de bom senso dos juízes do TC (é bem verdade que ninguém vê o argueiro no seu olho...). Sendo certo que o TC não atua por sua iniciativa, mas apenas a instâncias de umas poucas entidades (entre as quais o Presidente da República, um certo número de deputados, o Provedor de Justiça), temos de concluir que a falta de bom senso dos juízes do TC só se manifesta se todas estas entidades estiverem igualmente falhas do mínimo de bom senso.

Em 17 de outubro os jornais revelaram que o funcionário que representa em Lisboa a Comissão Europeia enviou para Bruxelas um memorando em que acusava o TC de 
ativismo político. No dia seguinte, um senhor que é membro do Conselho de Estado indicado pelo Presidente da República disse numa entrevista que a "classe política" deveria ter juizinho e aprovar a proposta de OE/2014 apresentada pelo governo, acrescentando que os juízes do TC fazem parte da "classe política" (o que talvez signifique que o senhor conselheiro de estado entende que o TC existe para fazer 'fretes' aos governos que não respeitam a Constituição). ${ }^{140}$

140 Outras vozes vêm alimentando o coro dos adeptos da 'diabolização’ do TC. Há dias, um banqueiro português não teve vergonha de dizer em público que o TC deveria ser envolvido nas conversações para estabelecer um consenso nacional acerca do caminho mais conveniente para o país... Como é possível que este senhor desconheça o princípio da separação dos poderes? Em um programa de televisão (14.10.2013), um 'comentador' (que já foi ministro das finanças de um governo do PS...) não se coibiu (para isso lhe pagam) de dizer o que segue: "onde não há dinheiro, não há Constituição, não há Tribunal Constitucional, nem coisíssima nenhuma”. E um outro, convidado para o mesmo programa, acusou o TC de querer "arrastar-nos para fora do euro"!

Já em dezembro/2013, os jornais noticiaram uma conferência feita nos EUA (perante 'investidores', segundo creio) por um professor universitário (com formação jurídica) que se diz ser assessor (oficial ou privado) do Primeiro-Ministro, durante a qual lamentou que Portugal sofresse a desgraça de ter uma "Constituição comunista", que aponta para a constituição de uma sociedade sem classes, e - talvez desgraça ainda maior! - de ter um Tribunal Constitucional fortemente empenhado em garantir o respeito desta constituição comunista. É a prova de que, para esta direita, vale tudo, sem recuar perante a mentira e desonestidade intelectual. $\mathrm{O}$ senhor professor sabe muito bem que os princípios que têm sido invocados pelo TC (e pelo Presidente da República e por outras entidades que têm solicitado a apreciação preventiva ou sucessiva da constitucionalidade de certas leis) são os princípios da igualdade, da proporcionalidade e da confiança, princípios que estão presentes em qualquer constituição de um país civilizado.

Alguns comentadores vão ao ponto de dizer que, na 'Europa', ninguém entende os poderes que tem o nosso Tribunal Constitucional. Fazem de contas que não sabem que ele tem as competências normais dos tribunais constitucionais dos países onde eles existem. E 'esquecem' que 
Mais preocupante é o facto de vermos instâncias muito mais poderosas do que as que acabo de referir declamar em público o mesmo discurso contra o Tribunal Constitucional português. Em maio/2013, o J. P. Morgan queixava-se, num dos seus relatórios, dos "profundos problemas políticos" que entravam os processos de ajustamento na zona euro, sublinhando que "os sistemas políticos da periferia foram estabelecidos no rescaldo de ditaduras e foram definidos por essas experiências". E logo desvenda onde está o gato: “os sistemas políticos da periferia (...) oferecem proteção constitucional aos direitos laborais (...) e o direito de protestar se forem feitas alterações indesejáveis ao status quo político". Como se vê, é um escândalo, para o grande capital financeiro, que as constituições protejam os direitos dos trabalhadores! Ainda mais intolerável: reconhecem aos trabalhadores o direito de protestar quando discordam de medidas ou políticas que afetam negativamente os seus direitos! Isto revela, a meu ver, uma dolorosa saudade do fascismo e uma vontade enorme de regressar a práticas fascistas.

Como quem está a 'jogar em casa', o dito relatório não se esquece de referir o nosso País (os nossos governantes devem ter ficado 'inchados' de orgulho patriótico!), apontando a Constituição da República Portuguesa como um exemplo dos "entraves" que "manietam os governos". ${ }^{141}$

Também na 1. a semana de outubro/2013 o Presidente da Comissão Europeia não se coibiu de dizer em público

na França o Conselho de Estado goza de um prestígio intocável e que na Alemanha o Tribunal Constitucional é quase uma entidade 'sagrada'. Nem o Presidente da Comissão Europeia ousa criticá-lo... E os alemães não esquecem o período da governação nazi, inspirada na real politik que os críticos do TC gostariam de garantir aos nossos governantes, 'esquecidos', pelos vistos, do que foi no nosso País, a governação-real-politik durante os 48 anos de fascismo. A falta de memória é uma doença perigosa!

${ }^{141}$ Ver J. Cadima, “Crise Estrutural”, cit. 
(ainda por cima em Portugal) que o nosso País tem de respeitar e cumprir os compromissos assumidos com a troika, tarefa em que todos os órgãos de soberania (incluindo, é claro, o TC) têm responsabilidades, ameaçando logo a seguir que, se assim não for, voltaremos a ter o caldo entornado. Fica por explicar o silêncio do Presidente da Comissão Europeia a propósito de várias intervenções do Tribunal Constitucional alemão sobre o projeto de integração europeia (por exemplo, já em plena crise, a decisão sobre a questão de saber se era ou não conforme à Constituição alemã que o estado alemão 'auxiliasse' os países do euro em dificuldade).

Em 7 de novembro a mesma personalidade insistiu na impertinência de pressionar o Tribunal Constitucional, sustentando que, se este não deixar passar todo o OE/2014, daí resultará a necessidade de o governo português adotar "medidas mais gravosas". Ora não cabe ao Presidente da Comissão Europeia fazer juízos sobre o que é mais ou menos gravoso para o povo português. Este é um juízo que cabe aos portugueses (e aos órgãos políticos resultantes do voto dos portugueses), que não passaram mandato para esse efeito ao Presidente da Comissão Europeia. Sua Excelência fala de medidas mais gravosas. Mais gravosas para quem? Para os funcionários públicos e para os reformados e pensionistas, se o Tribunal Constitucional os libertar do 'confisco' a que o governo os quer sujeitar? Para os contribuintes (i.é, para os que vivem dos rendimentos do trabalho e para os consumidores em geral, que são, na sua grande maioria, trabalhadores)? Para os que fazem sair diariamente rios de dinheiro para os paraísos fiscais? Para os titulares de 'rendas' (os parceiros privados das PPP e os acionistas das empresas monopolistas privatizadas que prestam serviços públicos: EDP, PT, REN, GALP, etc.)? Para as maiores empresas cotadas em bolsa, que, ganhando dinheiro em Portugal, sediaram as SGPS na Holanda, para lá pagarem impostos mais baixos, ganhando com 
a crise, sem suportarem qualquer sacrificio 'patriótico' para ajudar a ultrapassá-la? Ao falar como falou, o Presidente da Comissão Europeia está a formular juízos baseados nas suas próprias opções ideológicas (suas e da Comissão Europeia, do BCE, do FMI e dos demais 'donos' da Europa, detentores da 'verdade verdadeira' e guardiões dos dogmas indiscutíveis do neoliberalismo). E pretende levar o Tribunal Constitucional a orientar-se pela mesma bússula. É um comportamento inadmissível por parte de um funcionário internacional relativamente a um órgão de soberania (ainda por cima um Tribunal, cuja independência deveria respeitar) de um país soberano. A um nível ainda mais elevado (temos de reconhecer que o poder do atual Presidente da Comissão Europeia é um poder derivado e menor), a elegante Diretora-Geral do FMI, exibindo ignorância inadmissível ou má fé imperdoável, falou do TC como uma originalidade portuguesa, deixando no ar uma velada ameaça para o caso de esta 'originalidade' levantar algum obstáculo, em termos de inconstitucionalidade, ao cumprimento rigoroso do 'patriótico' programa de ajustamento imposto pela troika.

Num relatório divulgado em meados de novembro/2013, o próprio FMI sugere que Portugal tome medidas (que implicariam uma revisão da Constituição!) que impeçam os trabalhadores de recorrer aos tribunais quando forem despedidos sem justa causa. O que se propõe é uma subversão do nosso estado de direito democrático: os trabalhadores não podem ser considerados objetos descartáveis. Uma agência internacional como o FMI deveria ter mais recato e não vir a público estimular 'golpes de estado' contra a Constituição de um país soberano, que é membro do FMI. Já basta o que fez no Chile e em outras paragens.

Estes senhores parecem ignorar que, atuando deste modo, estão a violar o seu mandato, porque as organizações internacionais devem respeitar a soberania dos estados-mem- 
bros e as instituições que legitimamente a representam. E nem sequer respeitam os 'cabelos brancos' de um País como Portugal, que é um estado independente há quase 900 anos.

Mas talvez o mais importante a reter destes episódios é que todas estas vozes (desde os solistas até aos meninos do coro), ao 'diabolizar' o TC como se ele fosse um instrumento do império do mal, estão a veicular um discurso que me parece um discurso fascizante particularmente perigoso. ${ }^{142}$

${ }^{142}$ Por mim, desejo e espero que o TC decida com inteira independência, mantendo-se incólume às pressões a que vem sendo sujeito por parte de governantes mal agradecidos, que esquecem quão 'bonzinho' o TC tem sido para eles, em várias das suas decisões. Só dois exemplos: deixar passar o OE/2012, apesar de reconhecer que ele continha normas inconstitucionais; considerar constitucional o confisco, ainda por cima discriminatório, da contribuição extraordinária de solidariedade, imposta apenas aos pensionistas da CGA com pensões de 1.500 euros ou mais (se as condições do País impõem uma contribuição extraordinária de solidariedade, uma espécie de imposto de guerra (ou imposto patriótico, porque é de um imposto que estamos a falar, um imposto inconstitucional, porque tributa duplamente o rendimento já sujeito a IRS), então todos deverão contribuir: os trabalhadores no ativo e os reformados; as empresas e os empresários, os banqueiros e os bancos, as empresas industriais e os donos destas empresas, os profissionais liberais, enfim, os titulares de rendimentos do trabalho e os titulares de rendimentos do capital, bem como os titulares de grandes fortunas).

E foi 'amigo', mais uma vez, com o recente acórdão que considerou conforme à CRP o diploma legal que impõe aos trabalhadores da administração pública o horário semanal de 40 horas de trabalho. Marcelo Rebelo de Sousa foi duro na crítica, quando disse o TC “andou com o Governo ao colo", estranhando as diligências processuais promovidas pelo próprio TC, diligências que permitiram ao Governo fazer uma espécie de 'interpretação autêntica' de certas normas do diploma em análise, 'interpretação' nos termos da qual o Governo 'garantiu' ao Tribunal que o diploma em análise dizia, afinal, o que lá não está dito (e não está, manifestamente, porque o Governo não quis dizer o que agora, 'interpretando' as normas em apreço, garante ser o sentido do diploma). Não sei se a ciência jurídica ganhará alguma coisa com esta invenção (ou reinvenção) da interpretação autêntica, mas creio que nem a Constituição 
Um governo (o Parlamento ou o Presidente da República) não são legítimos só porque são eleitos. Para conservarem a legitimidade eleitoral têm que respeitar, em todos os seus atos, as regras de direito, particularmente as normas e os princípios constitucionais (os estados de direito são estados subordinados ao direito que eles próprios criam). Situações de excepção só as previstas na CRP : aquelas que justificam a declaração do estado de emergência ou do estado de sítio. Não é este o caso em Portugal. Por isso, ninguém pode invocar a "situação de emergência" em que o país vive (o que é isso de situação de emergência, que o próprio TC já utilizou - indevida e abusivamente, a meu ver - na sua argumentação ?), ou os compromissos com a troika para legitimar leis que violem os preceitos constitucionais (o famoso Memorando imposto pela troika nem sequer é um tratado internacional).

A "revolução conservadora" de que alguns falam, ao tentar justificar a 'legitimidade' para governar acima da lei e contra a Constituição, revela bem o projeto totalitário que

nem a lei orgânica do TC permitem que ele ande com o governo ao colo. De todo o modo, creio que não andou bem o TC ao aceitar como boa a 'interpretação autêntica' feita pelo Governo, em vez de decidir, como the competia, em função da sua própria interpretação das normas que estava a apreciar. Receio que, ao atuar deste modo, o TC se tenha colocado a si próprio à margem da Constituição que tem o dever de fazer respeitar. Este episódio foi, a meu ver, um momento infeliz na atuação do TC.

Mas o TC recuperou fôlego e prestígio ao decidir (19.12.2013), por unanimidade, a inconstitucionalidade das normas legais que inventaram uma fantasmagórica convergência das pensões da CGA com as do setor privado para, violando grosseiramente o princípio da confiança (o mesmo que dá estabilidade ao direito de propriedade), cortar $10 \%$ nas pensões dos aposentados como trabalhadores do estado. Foi um passo positivo, na ótica dos que, como eu, querem acreditar que o TC saberá honrar os seus pergaminhos, porque a cedência do TC ao discurso fascizante que anda no ar seria particularmente perigoso para a democracia. Em tempos de crise, mais do que em situações normais, precisamos de tribunais independentes e precisamos de acreditar na independência dos tribunais. 
está subjacente à ideologia neoliberal: a liberdade de escolha friedmaniana, 'descoberta' pelos 'revolucionários' de hoje, é apenas a outra face da morte da política, ou seja, da morte da cidadania e da morte da democracia. ${ }^{143}$ E representa uma forma velada de fascismo, o fascismo amigável ou o fascismo de mercado de que falo atrás: o único direito que vale é o direito do mais forte, aquele que, num jogo de concorrência pretensamente "livre e não falseada", vence o mais fraco, que não tem direitos nenhuns, porque perdeu. A liberdade de escolha esconde apenas a ideologia totalitária do pensamento único. ${ }^{144}$

No fim de um ciclo de crises recorrentes do capitalismo (iniciado com as crises do início da década de 1970, que tornaram evidente a tendência para a baixa da taxa de lucro e deixaram antever a possibilidade de uma grave crise estrutural), o grande capital financeiro (o agente responsável pelo crime sistémico que é a marca de água do capitalismo atual) convenceu-se de que o tempo dos compromissos necessários (estado social, concertação social entre parceiros sociais amigos) passou à história, porque a correlação de forças, no quadro de um mundo moldado pelas políticas de globalização neoliberal, lhe permite pôr os trabalhadores no seu lugar e impor políticas que levem até ao extremo a exploração de quem trabalha, na tentativa de contrariar a referida tendência para a baixa da taxa de lucro.

Os fascismos surgiram justamente nos países em que o estado capitalista não conseguiu, no respeito das regras democráticas, responder minimamente às aspirações dos tra-

${ }^{143}$ Ver o meu livro O estado capitalista..., cit., 192ss.

144 Transcrevo Eros Grau, professor aposentado da Faculdade de Direito da USP e ex-Juiz do Supremo Tribunal Federal (que, no Brasil, desempenha as funções de tribunal constitucional): "Quem quer impor os seus valores a qualquer custo mostra que não tem valor nenhum" e mostra "não saber nada do que significa a democracia" (entrevista a Juliano Basile, pouco antes de cessar funções no STF, publicada em CosTA, J. A. Fontoura e outros (Org.) - Direito:Teoria e Experiência..., cit., I, 26. 
balhadores e salvaguardar, ao mesmo tempo, o estatuto e os privilégios do capital. $\mathrm{O}$ que os discursos que acima refiro enunciam com suficiente clareza é a vontade do capital financeiro - que quer, a todo o custo, preservar e aumentar as rendas parasitas de que se alimenta - de levar por diante programas premeditados de anulação da soberania e de aviltamento da dignidade de países soberanos, programas bárbaros de empobrecimento e 'colonização' de povos inteiros, sem ter de respeitar qualquer lei ou qualquer princípio de ética política, em nome do princípio 'revolucionário' de que os fins justificam os meios, por mais cruentos que estes sejam.

29. À escala global, a presente crise do capitalismo tem evidenciado as debilidades e as contradições de um sistema económico e social que não vive sem situações recorrentes de desemprego e de destruição do capital em excesso e que hoje só sobrevive à custa do agravamento da exploração dos trabalhadores, para tentar contornar os efeitos da tendência para a baixa da taxa de lucro e para tentar satisfazer as rendas (verdadeiras rendas feudais) que são o suporte da hegemonia do grande capital financeiro. A discussão sobre o fim do estado social - que a crise tem dramatizado - talvez seja um sinal de que, como o aprendiz de feiticeiro, o capitalismo pode morrer imolado pelo fogo que está a atear. ${ }^{145}$

O Grupo de Reflexão constituído no âmbito do Conselho Europeu e presidido por Felipe González concluiu que, "pela primeira vez na história recente da Europa, existe um temor generalizado de que as crianças de hoje terão uma situação menos confortável do que a geração dos seus pais".

${ }^{145}$ Mark Bцyth (ob.cit., 34) deixa esta reflexão aos senhores do mundo: "Na essência, a democracia e as redistribuições que ela possibilita são uma forma de seguro de ativos para os ricos, e, mesmo assim, através da austeridade, descobrimos que aqueles que têm a maioria dos ativos andam a fugir ao pagamento do seguro". 
Nesta Europa do capital, um em cada quatro jovens não encontra um posto de trabalho. Na Grécia, um em cada cinco sem abrigo tem um curso superior. É uma catástrofe equivalente à perda de uma geração inteira numa guerra.

No Ano Europeu de Luta Contra a Pobreza, o Parlamento Europeu aprovou um Relatório onde se diz que, em 2010, cerca de 85 milhões de cidadãos da UE são afetados por situações de pobreza e de exclusão social e que mais de 19 milhões de trabalhadores europeus são considerados pobres.

São sinais de alarme particularmente significativos. Num mundo e num tempo em que a produtividade do trabalho atinge níveis até há pouco insuspeitados, talvez esta realidade (que quase parece mentira, de tão absurda que é) seja um alerta: ela pode significar que as contradições do capitalismo estão a atingir um limite insuportável. Em dezembro/2011, ao apresentar em Paris um Relatório da OCDE, o Secretário-Geral desta Organização recordava que, em virtude do aumento continuado das desigualdades sociais ao longo dos últimos trinta anos, "o contrato social está a desfazer-se em muitos países".

As 'reformas estruturais' de que tanto se tem falado neste tempo de crise estão a conduzir ao empobrecimento de povos inteiros, ao alargamento da mancha de pobreza e da exclusão social, ao aprofundamento da desigualdade, ao aumento dramático do número dos pobres que trabalham (mesmo nos países ditos ricos), justificando plenamente esta conclusão e justificando também todas as preocupações relativamente à preservação da democracia e da paz.

Porque o empobrecimento dos povos não os torna mais capazes para se desenvolver, nem mais competitivos; torna-os mais vulneráveis e menos capazes de progredir. Porque esta não é uma estratégia promotora do crescimento, muito menos do crescimento equilibrado de todos os povos da União e, ainda menos, uma estratégia de aproximação dos níveis de 
vida de todos eles. É uma estratégia de domínio 'colonial' em benefício exclusivo da elite 'colonialista'. Os mais débeis estarão cada vez mais no lugar da panela de barro, necessariamente esmagada pela panela de ferro.

É incontestável, por outro lado, que o alargamento da mancha de pobreza e da exclusão social que delas tem resultado é algo que põe em causa a própria civilização, nomeadamente as condições de vida em democracia. Porque a pobreza não significa apenas baixo nível de rendimento ou baixo poder de compra, ela priva as pessoas de capacidades básicas essenciais para a preservação e afirmação da sua dignidade enquanto pessoas. Amartya Sen tem sublinhado isto mesmo: "a privação de liberdade económica, na forma de pobreza extrema pode tornar a pessoa pobre presa indefesa na violação de outros tipos de liberdade". ${ }^{146}$ Uma situação de pobreza generalizada, acentuada e continuada não é compatível com a democracia. Vale a pena levar a sério a advertência de Paul Krugman a este respeito: "a concentração extrema do rendimento" significa "uma democracia somente de nome", "incompatível com a democracia real". ${ }^{147}$

30. O liberalismo económico funcionou nas condições históricas dos séculos XVIII e XIX, em que: a) a tecnologia industrial era relativamente rudimentar e adaptada a empresas de pequena dimensão; b) a concentração capitalista era inexistente ou pouco relevante; $\boldsymbol{c}$ ) os trabalhadores não estavam organizados (ou dispunham de organizações de classe de existência precária, débeis e inexperientes) e não gozavam da totalidade dos direitos civis e políticos (o que lhes dificultava e reduzia o acesso ao aparelho de estado e ao poder político e, consequentemente, a luta institucional pelos direitos económicos e sociais hoje reconhecidos constitucionalmente);

\footnotetext{
146 Cfr. A. SEN, ob. cit., 109.

147 Artigo no New York Times, 7.11.2011.
} 
d) os governos - imunes às exigências e aos votos populares - podiam, por isso mesmo, ignorar impunemente os sacrificios (e os sacrificados) das crises cíclicas da economia capitalista, qualquer que fosse a sua duração e intensidade.

Mas o mundo mudou, e, há mais de 50 anos, o argentino Raúl Prebisch (o primeiro Presidente da agência da ONU Comissão Económica para a América Latina) avisou que as soluções liberais só podem concretizar-se manu militari.

No início dos anos 1980 foi o insuspeito Paul Samuelson quem chamou a atenção para os perigos do "fascismo de mercado". E em 1981 Beltram Gross escreveu um livro sobre o "fascismo amigável".

Em 2011, tendo a crise como pano de fundo, Michel Rocard observou que, "no estado de exasperação em que este povo [o povo grego] se vai encontrar, é duvidoso que qualquer governo grego possa manter-se sem o apoio do exército. Esta triste reflexão é sem dúvida válida para Portugal ou para outros países maiores". E pergunta: "Até onde iremos?" 148

Em dezembro/2012, Federico Mayor Zaragoza (antigo Diretor-Geral da UNESCO) falou dos perigos do "golpe de mercado", sustentando que eles são a consequência das políticas prosseguidas por todos aqueles que "aceitaram, em certo momento histórico, substituir os princípios democráticos pelas leis do mercado". ${ }^{149}$

Todos temos a consciência de que nos estamos a afastar da democracia real. Por isso, é uma boa pergunta, a de Rocard: "Até onde iremos?" Perante o processo de empobrecimento acelerado a que se pretendem condenar os povos da Europa, acompanhado da um destruição das economias e da anulação das soberanias nacionais, faz todo o sentido, com efeito, temer pela própria democracia.

148 Le Monde, 4.10. 2011.

${ }^{149}$ Ver em http://www.other-news.info/noticias/, dez/2012. 
Quem não esquece as lições da história não pode ignorar que a ascenção do nazismo - e a barbárie que ele trouxe consigo - está intimamente ligada à forte depressão e aos elevados níveis de desemprego que marcaram a sociedade alemã no início da década de 1930, mais violentamente do que em outros países da Europa, também em resultado das políticas contracionistas e deflacionistas levadas a cabo pelo governo conservador de Heinrich Brüning.

Em 1943, Michael Kalecki formulou este diagnóstico: "O sistema fascista começa com o desenvolvimento do desemprego, desenvolve-se no quadro da escassez de uma 'economia de armamento' e termina inevitavelmente na guerra". ${ }^{150}$ Perante a chaga social do desemprego em massa que assola a Europa, tudo aconselha a que levemos muito a sério o aviso de Paul Krugman: "Seria uma insensatez minimizar os perigos que uma recessão prolongada coloca aos valores e às instituições da democracia". ${ }^{151}$

Quem conhece um pouco da história sabe que a democracia não pode considerar-se nunca uma conquista definitiva. É preciso, por isso, lutar por ela todos os dias, combatendo os dogmas e as estruturas neoliberais próprios do capitalismo dos nossos dias, porque este é, essencialmente, um combate pela democracia.

Todos os estudos de sociologia eleitoral mostram um perigoso esvaziamento da democracia representativa, perante o aumento contínuo do número de eleitores que se abstêm de participar nos atos eleitorais. É um fenómeno que se vem registando em todas as chamadas 'democracias ocidentais'. Mais de metade das eleições com mais baixa participação de eleitores realizaram-se depois de 2000, o que traduz, segundo Wolfgang Streeck, o progressivo enfraquecimento radical da democracia presente no "capitalismo democrático do

\footnotetext{
150 Ob. cit., 426.

151 Cfr. Acabem..., cit., 31.
} 
estado social", no quadro do "capitalismo reformado pelo neoliberalismo".

Ora, a meu ver, o neoliberalismo é uma ideologia que visa reverter em sentido favorável ao grande capital financeiro a correlação de forças entre o capital e o trabalho. E é claro que, nas sociedades de classes em que vivemos, o capitalismo pressupõe a existência do estado capitalista. E o neoliberalismo, ao contrário do que por vezes se quer fazer crer, não é uma ideologia libertária, que dispensa o estado. $\mathrm{O}$ império neoliberal foi construído, pedra a pedra, por obra do poder político (os estados nacionais dos países dominantes e as organizações internacionais dominadas pelo capital financeiro e pelos seus estados): foi o poder político que impôs a liberdade absoluta de circulação de capitais (a 'mãe' de todas as liberdades do capital); foi o poder político que desregulou todos os mercados (em especial os mercados financeiros, entregues ao "dinheiro organizado" comandado pelos especuladores, os 'padrinhos' do crime sistémico, a sida da economia mundial); foi o poder político que 'privatizou' os estados nacionais, tornando-os dependentes dos "mercados" para o financiamento das políticas públicas (é o que resulta do dogma da independência dos bancos centrais).

Para construir este 'império', o neoliberalismo precisou de um estado forte, que criou as condições para dispensar o compromisso dos tempos do estado social keynesiano, de modo a transferir para o capital os ganhos da produtividade, o que exigiu, como disse atrás, a 'guerra' contra os sindicatos, o esvaziamento da contratação coletiva, a 'flexibilização' da legislação laboral, a atrofia do estado social. E esta exigência permanece, porque o neoliberalismo não pode dispensar a violência de um estado forte, incompatível com um estado democrático. ${ }^{152}$

152 Cfr. supra, 23-25. 
31. Não quero ser pessimista, mas a verdade é que a persistência nas políticas da UE (disfarçada de troika ou atuando como tal ou como BCE) que estão a arruinar a economia dos 'países do sul' e a minar a sua soberania, bem como a insolência com que os governantes dos 'países do norte' vêm enxovalhando a dignidade dos 'países do sul', têm todas as caraterísticas de uma verdadeira guerra.

Porque é de 'guerra' que se trata quando os estados mais fortes e mais ricos da Europa humilham os povos dos países mais débeis, 'castigando-os' em público com 'penas infamantes' e condenando-os a um verdadeiro retrocesso civilizacional em nome da verdade dos 'catecismos' neoliberais impostos pelo grande capital financeiro. Como se diz atrás, o chamado Pacto Orçamental constitui um verdadeiro "golpe de estado europeu”, que, sob a capa de soluções 'técnicas', dá corpo a uma visão totalitária que suprime o que resta das soberanias nacionais, ignora a igualdade entre os estados-membros da UE, ofende a dignidade dos chamados 'povos do sul' e dos seus estados, e aponta para a colonização dos pequenos países pelos grandes.

Pode estar em perigo também a paz na Europa. Jean-Claude Juncker (Primeiro-Ministro do Luxemburgo e até há pouco Presidente da Eurogrupo) tem toda a razão quando diz que "está completamente enganado quem acredita que a questão da guerra e da paz na Europa não pode voltar a ocorrer. Os demónios não desapareceram, estão apenas a dormir, como mostraram as guerras na Bósnia e no Kosovo". ${ }^{153}$

153 Entrevista a Der Spiegel, 10.3.2013. 


\section{REFERÊNCIAS BIBLIOGRÁFICAS}

Amaral, João Ferreira do - Porque devemos sair do euro - $O$ divórcio necessário para tirar Portugal da crise, Lisboa, Lua de Papel, 2013.

Anderson, Perry - "A Europa face à hegemonia alemã”, em Le Monde Diplomatique (ed. port.), dez/2012.

Atтac - 'Constitution' Européenne - Ils se sont dit Oui, Paris, Mille et une Nuits, 2005.

Attali, Jacques - Verbatim I, Paris, Fayard, 1993.

Avelãs Nunes, A. J. - O keynesianismo e a contra-revolução monetarista, Coimbra, 1991 (separata do Boletim de Ciências Económicas);

- "Nota sobre a independência dos bancos centrais", em Ensaios de Homenagem a Manuel Jacinto Nunes, ISEG-UTL, Lisboa, 1996, pp. 405-423. Foi também publicado na revista Estudos Jurídicos (Pontifícia Universidade Católica do Paraná), vol. IV, n. ${ }^{\circ}$ 1, agosto/1997, 51-70;

- "Neoliberalismo, globalização e desenvolvimento económico", em Conferência Internacional Angola - Direito, Democracia, Paz e Desenvolvimento, edição da Faculdade de Direito da Universidade Agostinho Neto, Luanda, 2001, 103-163. Com ligeiras alterações, este texto foi publicado também no Boletim de Ciências Económicas (FDUC), vol. XLV (2002);

— "A institucionalização da União Económica e Monetária e os estatutos do Banco de Portugal", em Boletim de Ciências Económicas (FDUC), vol. XLV-A (especial), Coimbra, 2002, 65-98;

- Neoliberalismo e Direitos Humanos, Rio de Janeiro - São Paulo, Renovar, 2003 (135 págs.). Este livro foi também editado em Lisboa, Editorial Caminho, 2003;

- A Constituição Europeia: A Constitucionalização do Neoliberalismo, Coimbra, Coimbra Editora, 2006. Saiu uma edição para o Brasil ( $A$ Constituição Européia: A Constitucionalização do Neoliberalismo), com a chancela da Coimbra Editora e da Editora Revista dos Tribunais, São Paulo, 2007. O texto do livro foi publicado antes, com ligeiras alterações, no Boletim de Ciências Económicas, Vol. XLVIII (2005);

- A Crise do Capitalismo - Capitalismo, Neoliberalismo, Globalização, Lisboa, Página a Página, 5. edição, revista e ampliada, 2013;

- O estado capitalista e as suas máscaras (2. ${ }^{a}$ edição, revista, do livro As Voltas que o Mundo Dá... Reflexões a propósito das Aventuras e Desventuras do Estado Social, 1. ${ }^{a}$ edição, Edições Avante, 2010), Lisboa, Edições Avante, 2013. Uma edição brasileira, com texto ligeiramente diferente deste, acaba de ser publicada no Brasil, também com o título 
O estado capitalista e as suas máscaras (2. ${ }^{a}$ edição da edição brasileira de As Voltas que o Mundo Dá...), Rio de Janeiro, Lumen Juris, 2013;

- "Apontamento sobre a origem e a natureza das políticas de austeridade", em $A$ austeridade cura? A austeridade mata?, Eduardo Paz Ferreira (Coord.), Lisboa, Lisbon Law School Editions, 2013.

BARNIER, Michel - "Um grande passo para a estabilidade bancária”, em Diário Económico, 13.3.2013.

Barroso, Alfredo - "A crise da social-democracia europeia", em Le Monde Diplomatique (ed. port.), novembro/2011, 16/17.

Beck, Ulrich - A Europa Alemã - De Maquiavel a "Merkievel": Estratégias de Poder na Crise do Euro, trad. port., Lisboa, Edições 70, 2013.

Blaug, Mark - [1] - História do Pensamento Económico (2 vols.), trad. port. da 5. ${ }^{a}$ ed. inglesa (1985) de Economic Theory in Retrospect (1. ${ }^{a}$ ed., 1961), Dom Quixote, Lisboa, 1989/1990;

- [2] - A Metodologia da Economia, trad. port. da 2. ${ }^{a}$ ed. inglesa (1992), Gradiva, Lisboa, 1994 (1 ${ }^{\text {a }}$ ed. ing., 1980);

- [3] - Economic Theories, True or False? - Essays in the History and Methodology of Economics, Edward Elgar, Aldershot, 1990.

Blyth, Mark - Austeridade - A História de uma Ideia Perigosa, trad. port., Lisboa, Quetzal, 2013.

Cadima, Jorge - "Crise Estrutural”, em Avante!, 3.10.2013.

CALDAS, José Castro - “OE 2014: mais uma pedra no muro”, em Le Monde Diplomatique (ed. port.), nov./2013.

Carvalhas, Carlos - "O euro: questão fundamental na resposta à crise", em Le Monde Diplomatique (ed. port.), maio/2013.

Carvalho, Pedro - "O Pacto e o(s) PEC(s), mecanismos de exploração e a ofensiva do capital. O exemplo português no contexto europeu”, em Vértice, jan-fev/2011, 160-173.

Cassen, Bernard - "Ressurreição da 'Constituição' Europeia”, em Le Monde Diplomatique (ed. port.), dez/2007.

Castells, Manuel - A quién sirve el euro?, disponível em http://viva.org. $\mathrm{co} / \mathrm{cajavirtual/svc/articulo14.html.}$

Chevènement, Jean-Pierre - Pour l'Europe votez non!, Paris, Fayard, 2005.

Costa, J. A. Fontoura e outros (Org.) - Direito: Teoria e Experiência - Estudos em Homenagem a Eros Roberto Grau (2 tomos), São Paulo, Malheiros Editores, 2013.

Coutinho, Aldacy Rachid - "Direito capitalista e democrático do trabalho nos marcos do Estado Providência: 70 anos da Consolidação das Leis do Trabalho Brasileira", em Estudos do Século XX, n. ${ }^{\circ} 13$ (2013), 167-180.

Denord, François - “Desde 1958, a 'reforma' pela Europa”, em Le Monde Diplomatique (ed. port.), nov/2007. 
Denord, François e Antoine Schwartz - "Desde os anos 50 que cheira a oligarquia”, em Le Monde Diplomatique (ed. port.), julho/2009.

FERnANDES, Jorge Almeida - “Temos razões para detestar Merkel ? “, em Público, 11.8.2012, 22-24.

Ferreira, Domingos - "O império do mal”, em Público, 4.5.2012, 53.

Fligstein, Neil - "Markets as Politics: A Political-Cultural Approach to Markets Institutions", em ABOLAFIA, Mitchel Y. (Editor) - Markets, Vol. 7 de Critical Studies in Economic Institutions, An Elgar Reference Collection, 2005, 307-324.

Galamba, João - “Game Over”, em Le Monde Diplomatique (ed. port.), maio/2013.

Galbraith, James K. - “Que Europa para controlar os mercados?”, em Le Monde Diplomatique (ed. port.), junho/2010.

Gamble, Andrew - The Free Economy and The Strong State - The Politics of Thatcherism (2. ${ }^{a}$ edição), Londres, Macmillan, 1994.

GÉnÉreux, Jacques - Manuel Critique du Parfait Européen, Paris, Seuil, 2005.

Godelier, Maurice - Rationalité et Irrationalité en Économie, Paris, Maspéro, 1968.

Grau, Eros Roberto - "O Estado/estado da democracia”, em Estudos do Século XX, n. ${ }^{\circ} 13$ (2013), 25-29.

Green, David G. - The New Conservatism - The counterrevolution in political, economic and social thought, St. Martin's Press, New York, 1987.

Habermas, Jürgen - Um Ensaio sobre a Constituição da Europa, Lisboa, Edições 70, 2012.

Halimi, Serge - "As promessas do Não”, em Le Monde Diplomatique (ed. port.), junho/ 2005.

— "A esquerda governamental conta a sua história”, em Le Monde Diplomatique (ed. port.), abril/2007.

— "Estratégia para uma reconquista", em Le Monde Diplomatique (ed. port.), setembro/2013.

IAC (Iniciativa para uma Auditoria Cidadã à Dívida) - Conhecer a Dívida para sair da Armadilha, Relatório Preliminar do Grupo Técnico, 2013.

Hayek, Friedrich A. - "The Use of Knowledge in Society", em The American Economic Review,Vol. XXXV, n. ${ }^{\circ}$ 4, set/1945, 519-530.

- Law, Legislation and Liberty, Vol. II, The Mirage of Social Justice, Londres, Routledge, 1976.

JENNAR, Raoul-Marc - "Dois tratados para um golpe de estado europeu”, em Le Monde Diplomatique, ed. port., junho/2012.

JUDT, Tony - PÓS-GUERRA - História da Europa desde 1945, trad. port., Edições 70, Lisboa, 2007. 
Kalecki, Michael - "Political Aspects of Full Employment", em E. K. Hunt and Jesse G. Schwartz (Eds.), A Critique of Economic Theory. Selected Readings, Penguin Books, 1972, 420-430 (ensaio publicado originariamente em Political Quarterly,Vol. 14, 1943, 322-331.

Krugman, Paul - "Quando a austeridade falha", The New York Times, 25.5.2011 (publicado em Portugal pelo Jornal i).

- Acabem com esta Crise já!, Lisboa, Editorial Presença, 2012.

Lapavitsas, C., A. Kaltenbrunner, G. Lambrinidis e outros - "The Eurozone Between Austerity and Default", RMF Occasional Report, Setembro/2010, em www.researchonmoneyandfinance.org.

Lapavitsas, C., A. Kaltenbrunner, D. Lindo e outros - "Eurozone Crisis: Beggar Thyself and Thy Neighbour", RMF occasional report, março/2010, em www.researchonmoneyandfinance.org.

Lechevalier, A. e Wasserman, G. - La Constitution Européenne - Dix clés pour comprendre, Paris, La Découverte, 2005.

Lordon, Frédéric - "A desglobalização e os seus inimigos”, em Le Monde Diplomatique (ed. port.), agosto/2011.

— "Sair do euro, mas como?", em Le Monde Diplomatique (ed. port.), agosto/2013.

Louçã, Francisco e Mariana Mortágua, A DIVIDA(DURA) - Portugal na Crise do Euro, Lisboa, Bertrand Editora, 2012.

MÉszÁros, István - O Século XX - Socialismo ou Barbárie?, trad. bras., São Paulo, Boitempo, 2006.

Miliband, David - "The New Politics of Economics”, em Crouch, Colin and David Modigliani, Franco - "The Monetarist Controversy or, Should we Forsake Stabilization Policies?", em The American Economic Review, vol. 67, n. ${ }^{\circ}$ 2, março/1977, 1-19.

Morton, A. L. e George Tate: O movimento operário britânico, trad. port., Seara Nova, Lisboa, 1968.

Navarro, Vicenç, Juan Torres López y Alberto Garzón Espinosa - Hay Alternativas - Propuestas para crear empleo y bienestar social en España, Madrid, Ediciones Sequitur, 2011.

Plihon, Dominique - "Uma reforma bancária que encanta os banqueiros”, em Le Monde Diplomatique (ed. port.), março/2013, 12/13.

Quelhas, José Manuel Gonçalves Santos - "Sobre a criação do Comité Europeu do Risco Sistémico", em Estudos em Homenagem ao Prof. Doutor Aníbal Almeida (Orgs: António José Avelãs Nunes e outros), Coleção Studia Iuridica, Universidade de Coimbra/Coimbra Editora, Coimbra, 2012, 877-899.

— "Dos objetivos da União Bancária”, em Boletim de Ciências Económicas, Volume LV (2012), 241-303. 
Ribeiro, Sérgio - Não à Moeda Única: Um Contributo, Lisboa, Edições Avante, 1997.

RosA, Eugénio - "As verdadeiras ameaças à Segurança Social”, em Le Monde Diplomatique (ed. port.), nov./2013.

Rosas, J. Cardoso - "Euro versus Europa", em Diário Económico, 27.2.2013.

Santos Silva, Augusto - Os valores da esquerda democrática - Vinte teses oferecidas ao escrutínio público, Coimbra, Almedina, 2010.

Sarre, Georges - L'Europe contre la Gauche, Paris, Eyrolles, 2005.

Sen, Amartya - Desenvolvimento como liberdade, trad. bras., Companhia das Letras, São Paulo, 2000.

Smith, Adam - Riqueza das Nações (Vols. I e II), Edição da Fundação Calouste Gulbenkian, Lisboa,1981 e 1983.

Stiglitz, Joseph E. - Globalization and its Discontents (2002), trad. em castelhano, El Malestar en la Globalización, Madrid, Santillana Ediciones Generales, 2002.

- O Preço da Desigualdade, trad. port., Lisboa, Bertrand, 2013.

Streeck, Wolfgang - Tempo Comprado - A Crise Adiada do Capitalismo Democrático, trad. port., Lisboa, Conjuntura Actual Editora, 2013.

Stoскнамmer, Engelbert - "Neoliberalism, Income Distribution and the Causes of the Crisis", em http://researchonmoneyandfinance. org, versão 0.6:17 junho 2010 .

Teixeira Ribeiro, José Joaquim - Sobre o Socialismo, Coimbra, Coimbra Editora, 1991.

Teixeira, Pedro Braz - O Fim do Euro em Portugal?, Conjuntura Actual Editora, 2012.

Teixeira, Octávio - "Sair do euro é preciso", em Avante!, 8.11.2012.

— "Sair do euro e desvalorizar, a opção”, em Le Monde Diplomatique (ed. port.), maio/2013.

Teles, Nuno e Alexandre ABreu - "Sair do euro não é suficiente, mas é necessário", em Le Monde Diplomatique (ed. port.), maio/2013.

Treeck, Till Van - "Vitória de Pirro para a economia alemã", em Le Monde Diplomatique (ed. port.), setembro/2010.

Wallach, Lori - "Tratado Transatlântico: um tufão que ameaça os europeus”, em Le Monde Diplomatique (ed. port.), nov/2013. 
Resumo: O A. analisa o processo de criação e de desenvolvimento da CEE e da UE, pondo em relevo a sua inspiração liberal e o défice democrático que tem caraterizado o processo de integração europeia.

Analisa depois o papel do estado capitalista e do mercado (enquanto "instituição política" e elemento essencial da 'ordem capitalista') na prossecução dos objetivos do chamado consenso de Washington, no âmbito da contra-revolução monetarista e das políticas de globalização neoliberal.

Olhando para a UE, dá conta das consequências da criação da UEM e das suas repercussões na crise actual, crise do capitalismo, crise do euro e crise da Europa, apresentada capciosamente como crise das dívidas soberanas dos povos bárbaros do sul.

Dá conta do papel do euro como deutsche euro e destaca a importância do programa neo-mercantilista da Agenda 2010, da responsabilidade do governo social-democrata de Gerhardt Schröder, na estratégia de domínio da Alemanha, até se chegar à "europa alemã” dos dias de hoje.

O A. aborda a seguir o Tratado Orçamental e o seu significado como verdadeiro 'pacto colonial', como instrumento de um novo Leviathan, como alicerce de uma espécie de programa de austeridade perpétua.

Passa depois a outro ponto: a análise dos problemas que se colocam a propósito de uma eventual saída do euro.

$\mathrm{Na}$ parte final, o texto analisa o significado das propostas federalistas de 'mais Europa', associando esta problemática aos perigos para a democracia e para a paz que ameaçam a Europa, em consequência das opções políticas que vêm sacrificando a Europa social à Europa do capital.

Palavras-chave:Agenda 2010; Banco Central Europeu; Consenso de Washington; crime sistémico; défice democrático; estado capitalista; euro; Europa do capital; Europa social; federalismo europeu; gestão leal do capitalismo; globalização; Leviathan; mercado; mercado comum; neoliberalismo; políticas de austeridade; Tratado Orçamental; União Bancária; União Económica e Monetária; União Europeia.

The euro: from the promises of Paradise to the threats of endless austerity

Abstract: The A. analyses the creation and development of EEC and EU, stressing its liberal inspiration and the democratic deficit that characterized the process of European integration.

He then analyses the role both of the capitalist state and of the market (as a "political institution" and an essential element of the "capitalist 
order") in the achievement of the objectives of the so-called Washington Consensus, within the monetarist counter-revolution and neoliberal globalization policies.

With regard to the EU, he gives notice of the consequences of the creation of the EMU and of its repercussions in the present crisis, which is a crisis of capitalism, a crisis of the euro and a crisis of Europe, in spite of being captiously presented as a crisis of the sovereign debt of the barbarian peoples of the south.

He gives notice of the role of the euro as deutsche euro and highlights the importance of the neo-mercantilist programme of Agenda 2010 , as well as the responsibility of the social-democrat government of Gerhardt Schröder in Germany's strategy towards domination, until reaching the present "German Europe".

The A. then refers to the Fiscal Stability Treaty and to its meaning as a true "colonial pact", as an instrument of a new Leviathan, as the cornerstone of a sort of endless austerity programme.

$\mathrm{He}$ subsequently focuses the problems that would arise in the eventuality of an exit from the euro.

In the final part, the text analyses the meaning of the federalist proposals of "more Europe", associating this issue with the dangers to democracy and peace that threaten Europe as a consequence of the political options that have been sacrificing social Europe to Europe of capital.

Keywords:Agenda 2010; austerity policies; Banking Union; capitalist state; common market; democratic deficit; Economic and Monetary Union; Euro; Europe of capital; European Central Bank; European federalism; European Union; Fiscal Stability Treaty; globalization; Leviathan; loyal management of capitalism; market; neoliberalism; social Europe; systemic crime; Washington Consensus.

António José Avelãs Nunes

Faculdade de Direito da Universidade de Coimbra 